\title{
Discovery of Lysine-Targeted elF4E Inhibitors through Covalent Docking
}

Xiaobo Wan, Tangpo Yang, Adolfo Cuesta, Xiaming Pang, Trent E. Balius, John Irwin, Brian K. Shoichet, and Jack Taunton

\section{Supplementary figures and tables:}

Figure S1: Preparation of Lys rotamers for covalent docking

Table S1: Retrospective test of covalent docking method using a library of predicted Lys rotamers

Table S2: Overview of compounds 1-7 prioritized by covalent docking

Figure S2: Virtual library for secondary covalent docking screen

Figure S3: LC-MS/MS analysis of elF4E treated with compound 9

Figure S4: Overlay of predicted docking models with cocrystal structures

Figure S5: Structural models of compounds 10-12 bound to elF4E

Figure S6: Kinetic characterization of elF4E labeling by compounds 10-12

Figure S7: Covalent modification of WT and K162R elF4E by compounds 9-12

Figure S8: Reaction of S92H elF4E with compound 12

Figure S9: Absolute intensity values from firefly and Renilla luciferase assays

Figure S10: Time-dependent decrease of covalently modified elF4E in cells

Figure S11: Chemical stability of compound 12

Table S3: X-ray data collection and refinement statistics

General materials and methods

Compound synthesis and characterization 

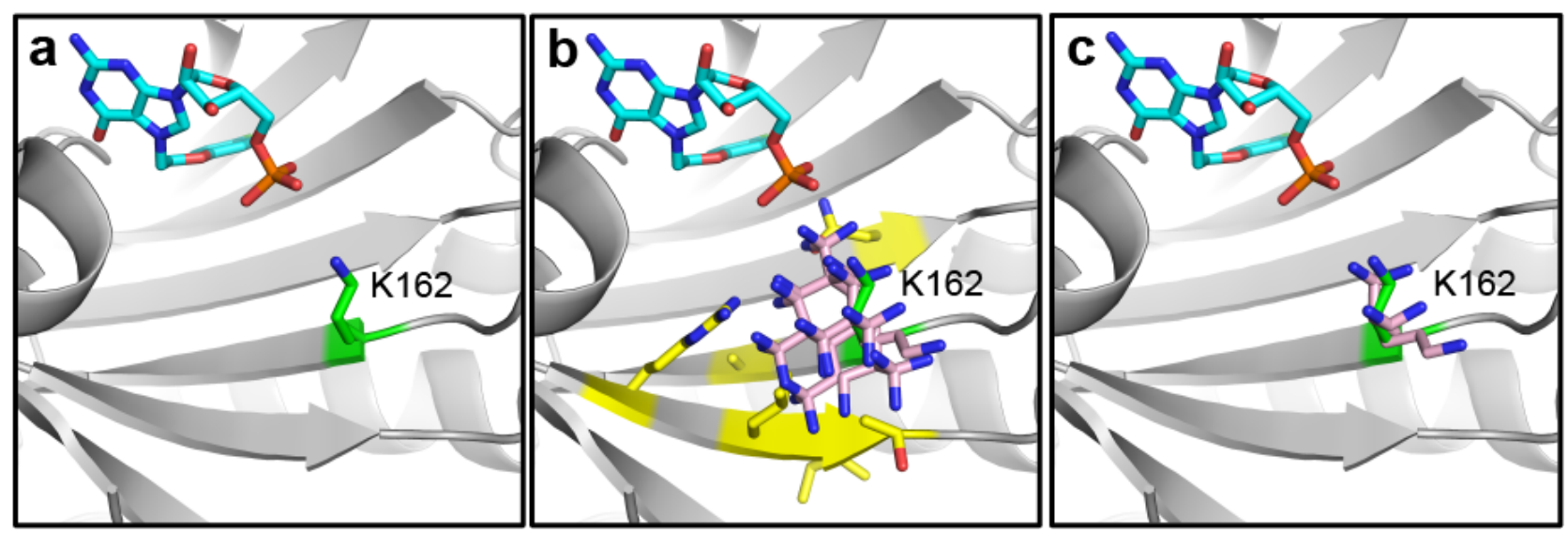

Figure S1. Preparation of Lys rotamers for covalent docking. (a) In this example (PDB ID 4DT6), Lys162 in the elF4E cap binding site is shown in green. (b) 27 Lysine rotamers were generated based on the Penultimate Rotamer Library (pink). Rotamers that clashed with adjacent residues (yellow) were excluded. (c) Finally, five lysine rotamers (pink) as well as the crystallographic rotamer were selected for covalent docking. 


\begin{tabular}{|c|c|c|c|c|c|c|}
\hline PDB ID & $\begin{array}{l}\text { Reactive } \\
\text { Residue }\end{array}$ & $\begin{array}{l}\text { Lysine } F \\
\text { rotamers }\end{array}$ & $\begin{array}{l}\text { RMSD of top-scoring } \\
\text { pose }(\AA)\end{array}$ & $\begin{array}{l}\text { Lowest RMSD of } \\
\text { top } 1,000 \text { poses }(\AA)\end{array}$ & $\begin{array}{c}\text { RMSD of lowest top } \\
1,000 \text { poses after } \\
\text { minimization }(\hat{A})\end{array}$ & Protein family \\
\hline $1 \mathrm{E} 7 \mathrm{U}$ & 833 & 4 & 5.5 & 1.4 & 0.8 & Phosphatidylinositol-3 kinase \\
\hline $2 \mathrm{G} 6 \mathrm{~W}$ & 236 & 1 & 7.9 & 5.5 & 5.8 & 8-amino-7-oxononanoate synthase \\
\hline $3 D 5 X$ & 68 & 8 & 3.0 & 1.4 & 1.1 & Polo-like kinase 1 \\
\hline 3G3M & 125 & 9 & 1.5 & 1.4 & 1.2 & $\begin{array}{c}\text { Uridine 5'-monophosphate } \\
\text { synthase }\end{array}$ \\
\hline 3SW6 & 72 & 10 & 2.0 & 1.6 & 1.3 & $\begin{array}{l}\text { Orotidine 5'-phosphate } \\
\text { decarboxylase }\end{array}$ \\
\hline 4 A29 & 210 & 8 & 1.3 & 0.7 & 0.4 & Engineered retro-aldolase \\
\hline $4 \mathrm{CDL}$ & 88 & 5 & 2.5 & 0.8 & 0.5 & Retro-aldolase \\
\hline $4 \mathrm{DKL}$ & 233 & 6 & 4.2 & 2.8 & 2.8 & Mu-opioid receptor \\
\hline $4 \mathrm{FI} 8$ & 15 & 5 & 6.0 & 2.4 & 2.5 & Transthyretin \\
\hline 4PJE & 43 & 1 & 1.5 & 1.2 & 0.9 & $\begin{array}{l}\text { Major histocompatibility complex } \\
\text { class I-related gene protein }\end{array}$ \\
\hline 4PL3 & 907 & 0 & NA & NA & NA & $\begin{array}{l}\text { Serine/threonine-protein kinase } \\
\text { IRE1 }\end{array}$ \\
\hline $5 \mathrm{CYI}$ & 89 & 13 & 10.2 & 2.4 & 1.9 & Cyclin-dependent kinase 2 \\
\hline $5 \mathrm{HUQ}$ & 184 & 5 & 1.7 & 1.4 & 1.2 & $\begin{array}{l}\text { Lactate racemization operon } \\
\text { protein LarA }\end{array}$ \\
\hline $5 \mathrm{IEL}$ & 1 & 8 & 4.3 & 3.7 & 4 & Lysozyme C \\
\hline $5 \mathrm{~K} 9 \mathrm{I}$ & 295 & 9 & 1.4 & 1.3 & 1.4 & $\begin{array}{l}\text { Proto-oncogene tyrosine-protein } \\
\text { kinase Src }\end{array}$ \\
\hline 5U8L & 745 & 3 & 10.8 & 1.3 & 1.1 & $\begin{array}{l}\text { Epidermal growth factor receptor } \\
\text { kinase }\end{array}$ \\
\hline \multicolumn{7}{|c|}{ Summary of Pose Prediction Results on the 16 Complexes } \\
\hline & Mean & 6 & 4.3 & 1.9 & 1.8 & \\
\hline \multicolumn{3}{|c|}{ Success number (RMSD $<2$ A) } & $6 / 16$ & $10 / 16$ & $11 / 16$ & \\
\hline \multicolumn{3}{|c|}{ Success rate $(R M S D<2 \AA)$} & $37.5 \%$ & $62.5 \%$ & $68.8 \%$ & \\
\hline
\end{tabular}

Table S1. Retrospective test of covalent docking method using a library of predicted Lys rotamers. We retrospectively tested our covalent docking method on a set of cocrystal structures containing 16 Lys-targeted covalent ligands. In this test, each covalently modified Lys side chain was first removed and then replaced with a library of Lys rotamers as described in Figure S1. Covalent docking was then performed against all reasonable Lys rotamers (lacking steric clashes). Shown are RMSD values for the ligand heavy atoms between the top-scoring pose and the crystal structure. The pose with the lowest RMSD among the top 1,000-scoring poses was selected and saved for minimization refinement, after which the RMSD was recalculated. Also shown is the success rate (\% docking tests with RMSD $\leq 2 \AA$ ) for the topscoring docking pose, the lowest RMSD among the top 1,000-scoring docking pose, and the lowest RMSD pose after minimization. NA: no Lys rotamer from the library was accepted due to steric clashes. 


\begin{tabular}{|c|c|c|c|c|c|c|c|}
\hline Compound & $\begin{array}{l}\text { Modified WT } \\
\text { elF4E (\%) }\end{array}$ & $\begin{array}{l}\text { Modified K162R } \\
\text { elF4E (\%) }\end{array}$ & $\begin{array}{l}\text { Starting structure } \\
\text { (PDB ID) }\end{array}$ & $\begin{array}{c}\text { DOCK score } \\
(\mathrm{kcal} / \mathrm{mol})\end{array}$ & DOCK rank & $\begin{array}{l}\text { Minimization } \\
\text { score } \\
(\mathrm{kcal} / \mathrm{mol})\end{array}$ & $\begin{array}{l}\text { Minimization } \\
\text { rank }\end{array}$ \\
\hline 1 & $1.9 \pm 2.7$ & $0.0 \pm 0.0$ & 4DUM & -19.7 & $130 / 219$ & -107.6 & $2 / 219$ \\
\hline 2 & $38.8 \pm 2.8$ & $27.9 \pm 1.1$ & 4DT6 & -29.0 & $11 / 219$ & -103.8 & $15 / 219$ \\
\hline 3 & $41.7 \pm 1.0$ & $37.5 \pm 0.8$ & 4DT6 & -33.2 & $2 / 219$ & -103.4 & $20 / 219$ \\
\hline 4 & $15.6 \pm 1.3$ & $10.1 \pm 2.2$ & 4DUM & -30.2 & $7 / 219$ & -101.9 & $32 / 219$ \\
\hline 5 & $20.7 \pm 1.2$ & $18.5 \pm 1.0$ & 4DT6 & -25.2 & $55 / 219$ & -96.8 & $112 / 219$ \\
\hline 6 & $10.6 \pm 1.0$ & $11.1 \pm 1.3$ & 4DT6 & -25.2 & $54 / 219$ & -96.6 & $119 / 219$ \\
\hline 7 & $16.0 \pm 1.3$ & $9.7 \pm 2.3$ & 4DUM & -27.8 & $21 / 219$ & -94.3 & $148 / 219$ \\
\hline
\end{tabular}

Table S2. Overview of compounds 1-7 prioritized by covalent docking. Shown for each compound are initial docking and minimization (MM/GBSA) scores, ranking before and after minimization, and the starting elF4E structure (PDB ID 4DT6 or 4DUM) that led to the best docking score. Only $0.24 \%$ of the docked library (219/88186) had poses consistent with key interactions for which we filtered (see the "Post-docking pose analysis section"). Those that did were scored by DOCKovalent and then refined by minimization and rescoring. Arylsulfonyl fluorides 1-7 were purchased from Enamine and tested for their abilities to covalently modify WT and K162R elF4E. Purified recombinant WT and K162R elF4E were treated with compounds 1-7 $(100 \mu \mathrm{M})$ for $3 \mathrm{~h}$ at RT $(\mathrm{pH} 8.1)$, followed by LC-MS analysis. Shown is the percentage of modified elF4E (means $\pm S D, n=2$ ). 
a<smiles>O=Cc1ccncc1</smiles>

b

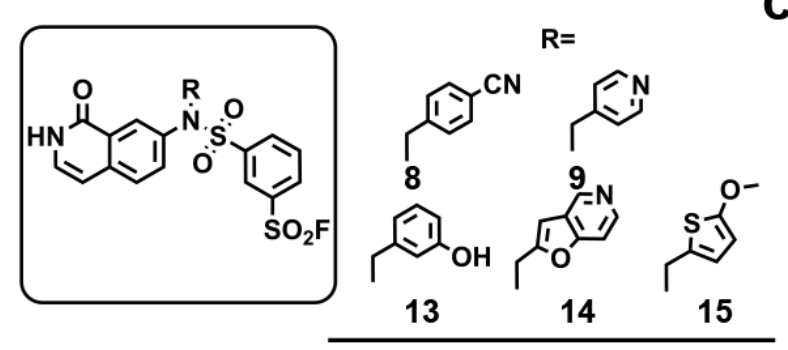

d

\begin{tabular}{crccccr}
\hline Compound & $\begin{array}{c}\text { Modified WT } \\
\text { elF4E (\%) }\end{array}$ & $\begin{array}{c}\text { Starting } \\
\text { structure } \\
\text { (PDB ID) }\end{array}$ & $\begin{array}{c}\text { DOCK } \\
\text { score } \\
(\mathrm{kcal} / \mathrm{mol})\end{array}$ & $\begin{array}{c}\text { DOCK } \\
\text { rank }\end{array}$ & $\begin{array}{c}\text { Minimization } \\
\text { score } \\
(\mathrm{kcal} / \mathrm{mol})\end{array}$ & $\begin{array}{c}\text { Minimization } \\
\text { rank }\end{array}$ \\
\hline 8 & $82.9 \pm 0.1$ & 4DT6 & -22.2 & $374 / 428$ & -117.6 & $13 / 428$ \\
9 & $61.9 \pm 2.3$ & 4DT6 & -29.7 & $193 / 428$ & -111.9 & $130 / 428$ \\
13 & $2.2 \pm 1.3$ & 4DT6 & -28.8 & $220 / 428$ & -112.8 & $94 / 428$ \\
14 & $42.3 \pm 0.1$ & 4DT6 & -30.8 & $170 / 428$ & -114.9 & $42 / 428$ \\
15 & $8.4 \pm 1.3$ & 4DT6 & -19.3 & $412 / 428$ & -110.9 & $187 / 428$ \\
\hline
\end{tabular}

Figure S2. Virtual library for secondary covalent docking screen. (a) Synthesis scheme for the virtual library used in the secondary docking screen. (b) Compounds 8, 9, 13-15 prioritized and synthesized by Enamine. (c) elF4E $(1 \mu \mathrm{M})$ was treated with compounds 2, 8, 9, 13-15 (50 $\mu \mathrm{M})$. At the indicated time points, WT elF4E modification (\%) was quantified by LC-MS. (d) Shown for each compound is the percent elF4E modification after $3 \mathrm{~h}$ (means $\pm S D, n=2$ ), docking and minimization (MM/GBSA) scores, ranking before and after minimization. 19\% of the docked library (428/2239) generated poses consistent with key interactions for which we filtered (see the "Post-docking pose analysis"); these were scored by DOCKovalent and then refined by minimization and rescoring. 


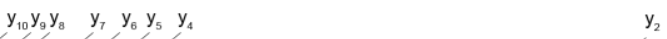

a GDK(Compd9)IAIWTTEC(Carbamidomethyl)ENR ${ }^{+2}$

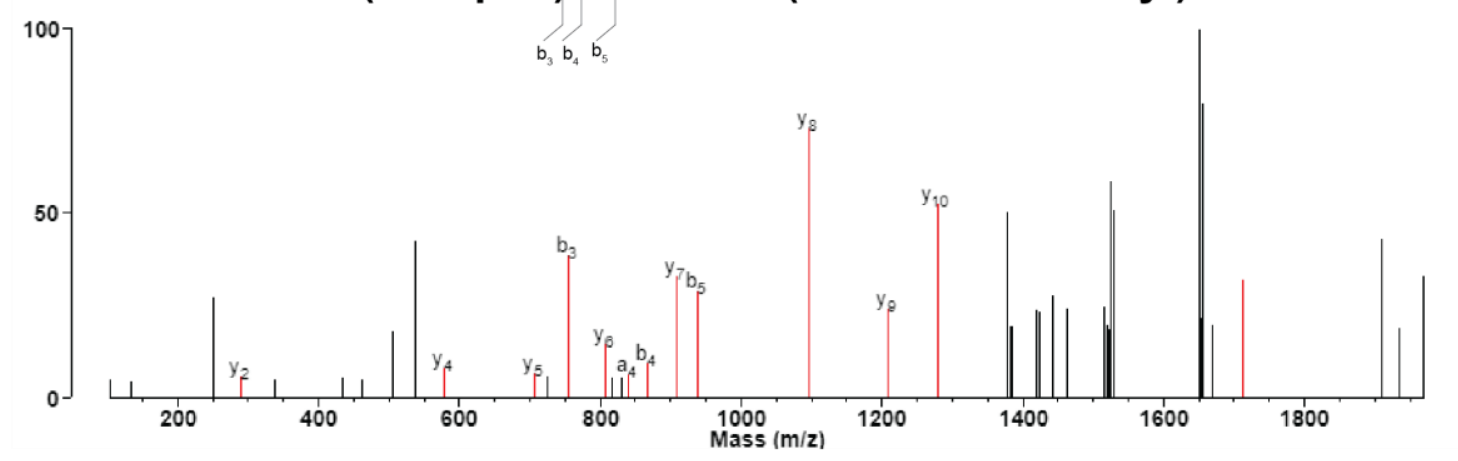

b

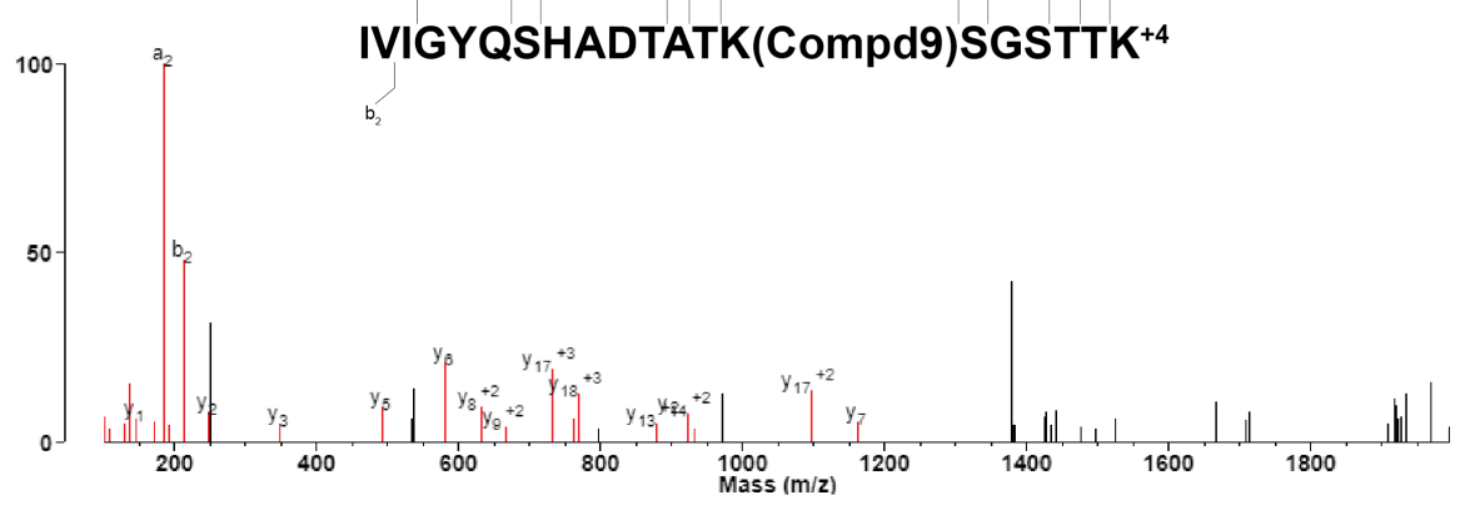

Figure S3. LC-MS/MS analysis of elF4E treated with compound 9. WT elF4E $(1 \mu \mathrm{M})$ was treated with compound $9(50 \mu \mathrm{M})$ at RT for 6 or $24 \mathrm{~h}$, followed by subsequent DTT reduction, alkylation with iodoacetamide, and trypsin digestion. Tryptic peptides were analyzed by LC-MS/MS. Shown are MS2 spectra corresponding to elF4E tryptic peptides covalently modified by compound 9 at K162 (a) and K206 (b). After 6 h, K162 was the only modification site detected, whereas after 24 h, K162 and K206 were the only modification sites detected. 

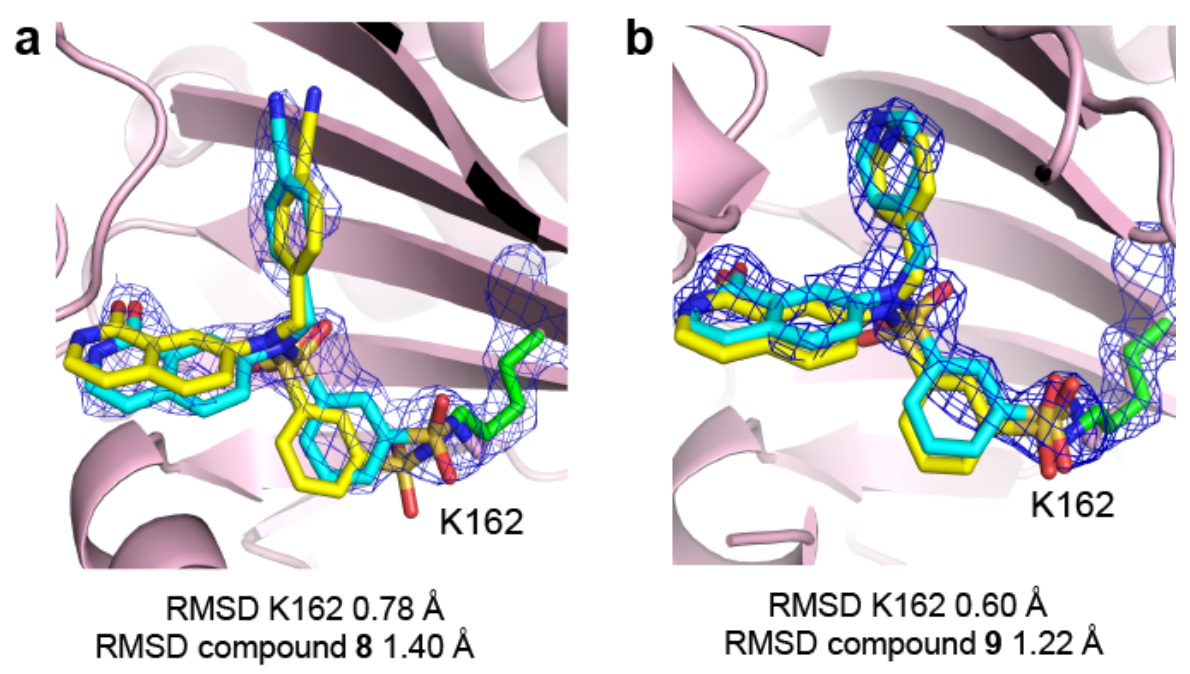

Figure S4. Overlay of predicted docking models with cocrystal structures. Electron density maps $\left(2 F_{o}-F_{c}\right)$ are shown at a contour level of $1 \sigma$. Ligands in the crystal structures (PDB ID $6 \mathrm{U} 06$ for 8 and $6 \mathrm{U} 09$ for 9) are in cyan, and docking poses are in yellow. Lys162 in each docking model is in green. RMSD values for Lys 162 and compounds $\mathbf{8}$ and $\mathbf{9}$ were calculated by overlaying crystal structures and docking models. 


\begin{tabular}{ccc} 
a & \\
& & \\
\hline Compound & $\begin{array}{c}\text { DOCK score } \\
(\mathrm{kcal} / \mathrm{mol})\end{array}$ & $\begin{array}{c}\text { Minimization score } \\
(\mathrm{kcal} / \mathrm{mol})\end{array}$ \\
\hline 10 & -9.3 & -116.6 \\
11 & -20.3 & -124.8 \\
12 & -8.9 & -126.5 \\
\hline
\end{tabular}

b Model of compound 10
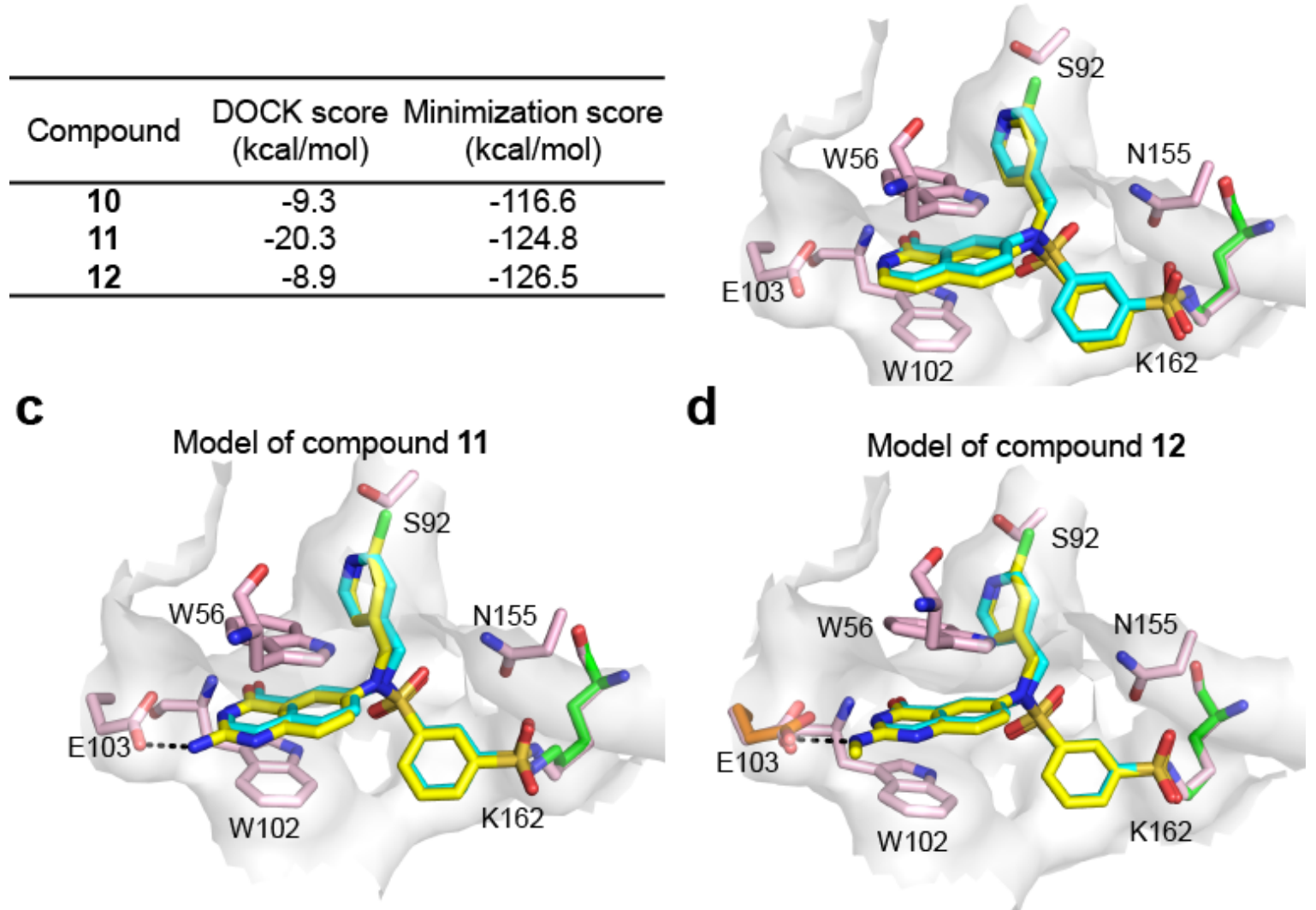

d

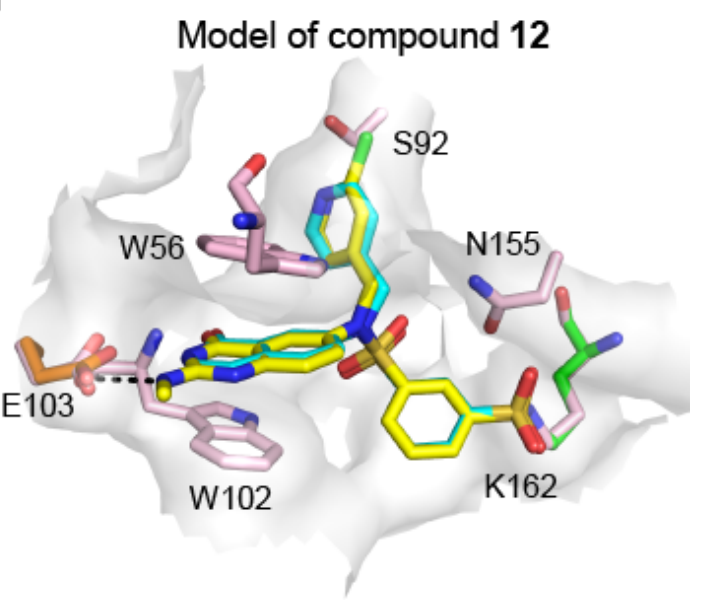

Figure S5. Structural models of compounds 10-12 bound to elF4E. (a) Docking and MM/GBSA scores for compounds 10-12. Docking of 10-12 used the crystal structure of compound 9/elF4E (PDB ID 6U09). (b-d) Docking models of 10-12 (yellow) aligned with the crystal structure of compound $\mathbf{9}$ (cyan) bound to elF4E (pink side chains, gray surface). 


\section{a}

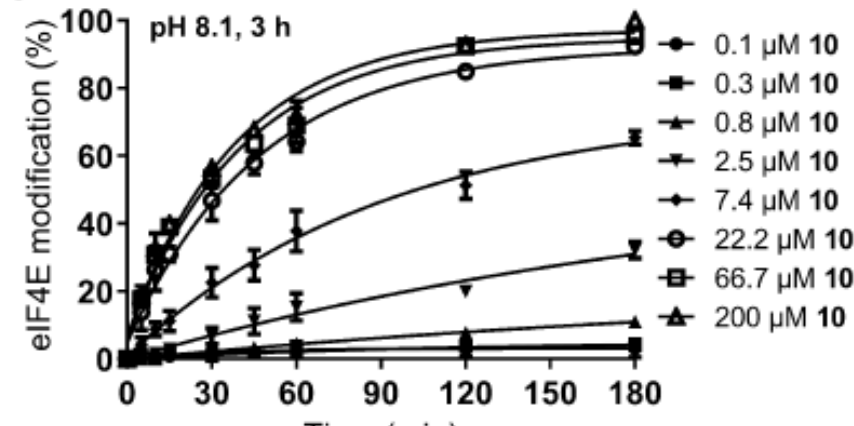

C $\mathrm{pH} 8.1,1 \mathrm{~h}$ Time (min)

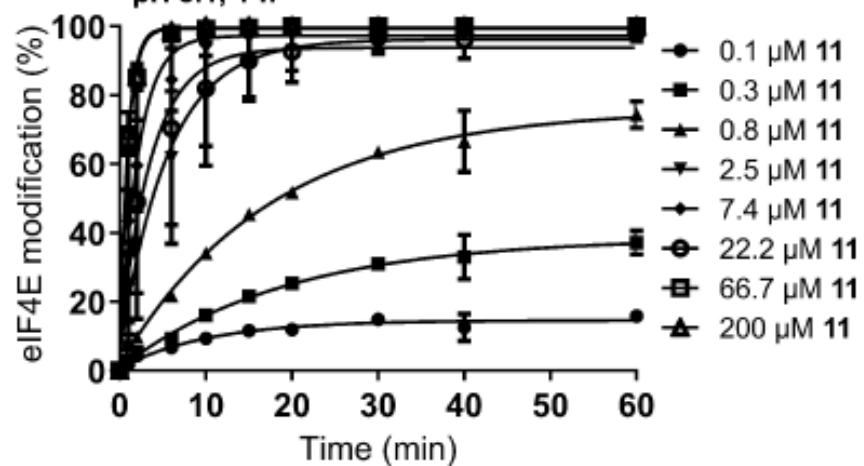

e

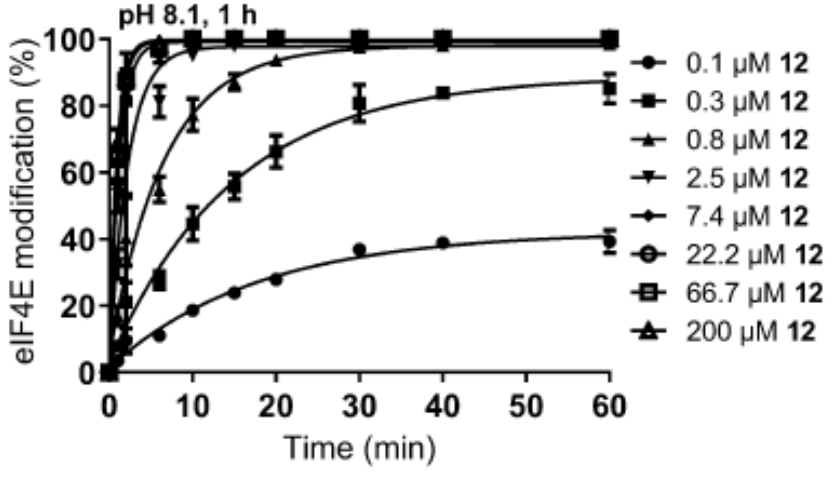

b
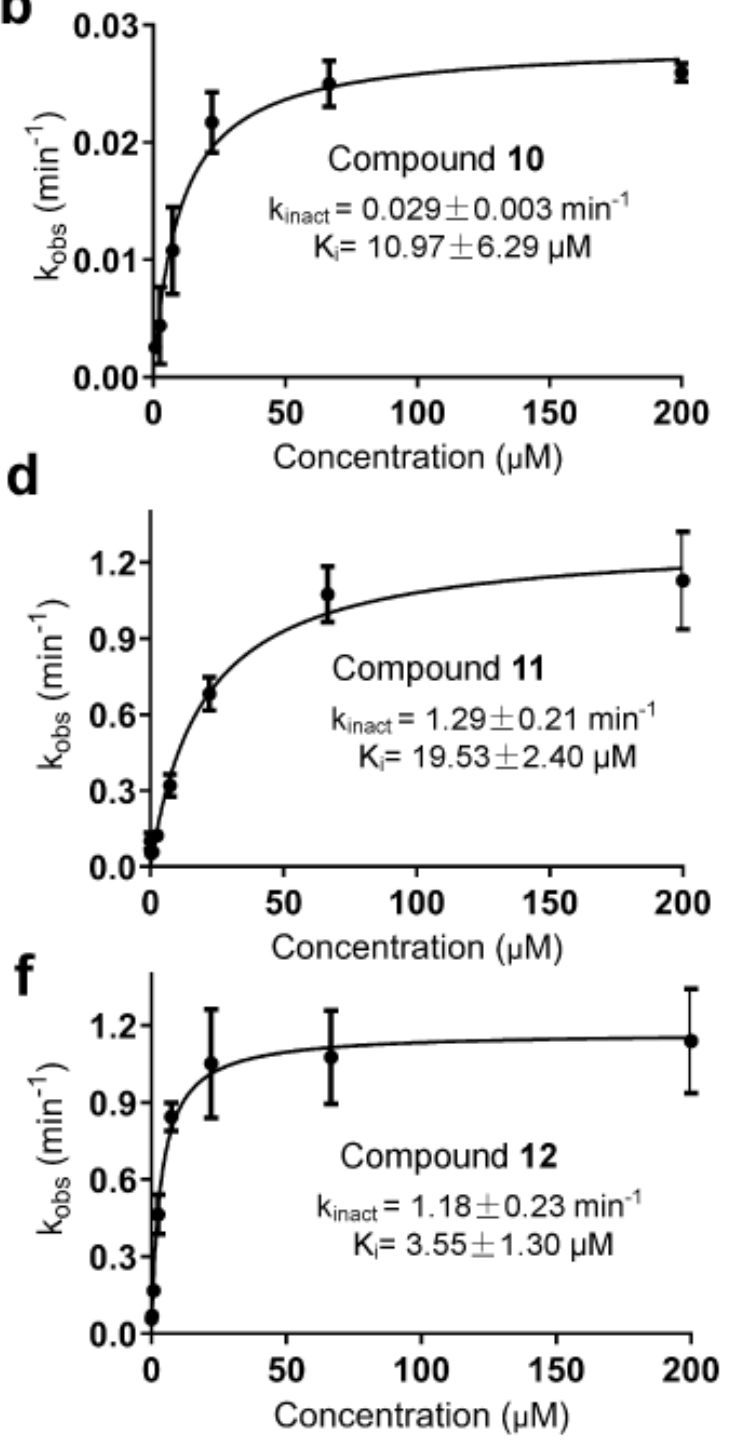

Figure S6. Kinetics of elF4E labeling by compounds 10-12. Reaction progress curves for elF4E labeling by the indicated concentrations of compounds $\mathbf{1 0}$ (a), 11 (c) and 12 (e). Progress curves were fit to a single phase exponential to obtain $k_{\text {obs }}$. Kinetic parameters $\mathrm{K}_{\text {inact }}$ and $\mathrm{K}_{\mathrm{i}}$ were obtained by plotting kobs vs. concentration for compound 10 (b), 11 (d) and 12 (f). 


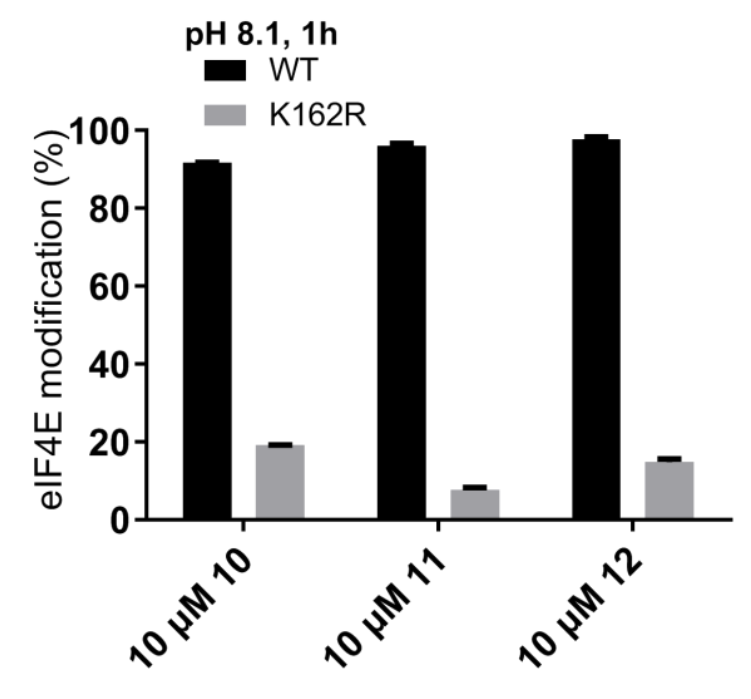

Figure S7. Covalent modification of WT and K162R elF4E by compounds 9-12. WT and K162R elF4E $(0.5 \mu \mathrm{M})$ were treated with compounds 9-12 $(10 \mu \mathrm{M})$. After $1 \mathrm{~h}$ at RT, elF4E modification (\%) was quantified by LC-MS (means $\pm \mathrm{SD}, \mathrm{n}=2$ ). 


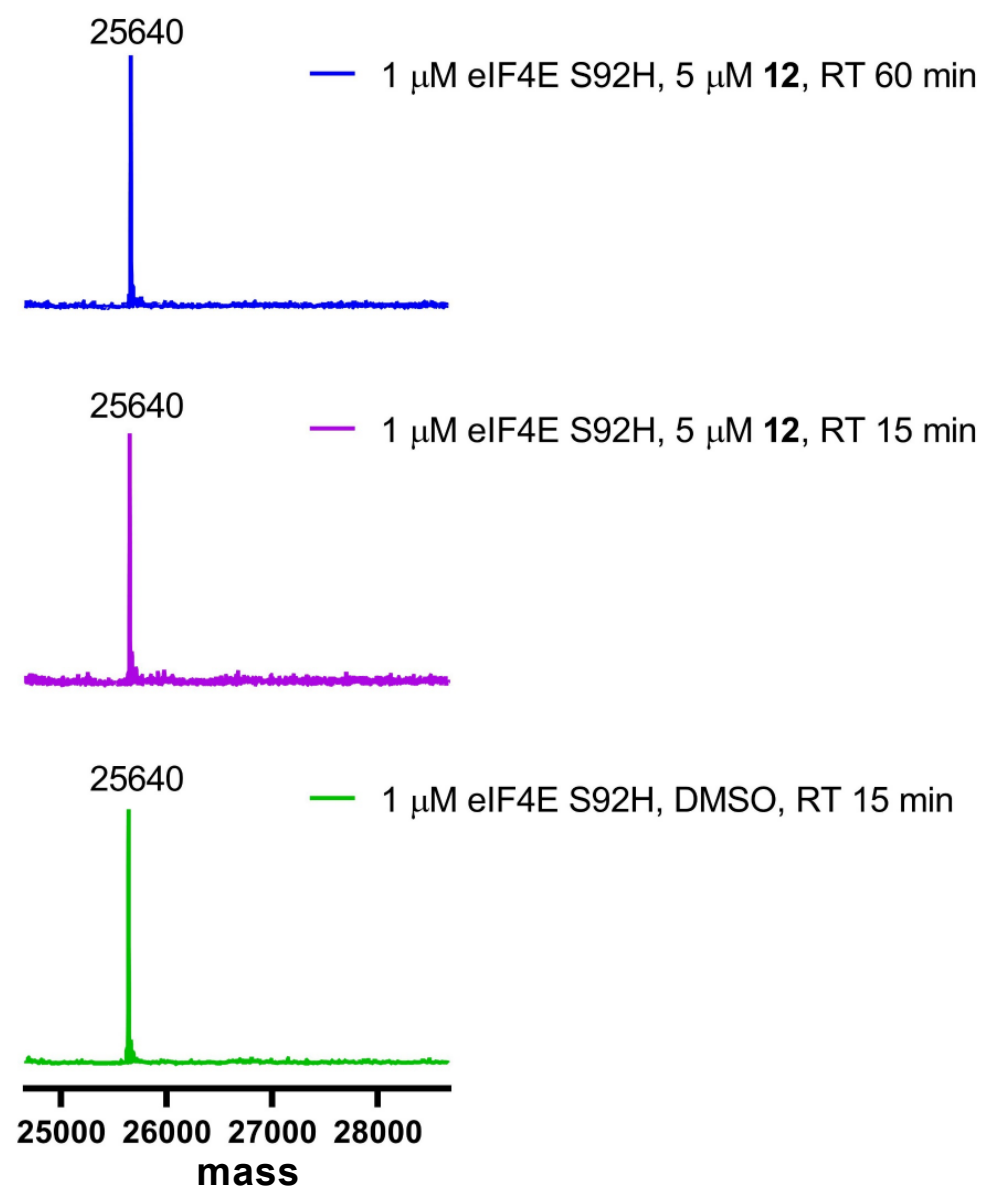

Figure S8. Reaction of S92H elF4E with compound 12. S92H elF4E $(1 \mu \mathrm{M})$ was treated with compound $12(5 \mu \mathrm{M})$ at RT for $15 \mathrm{~min}$ and $60 \mathrm{~min}$ and analyzed by LC-MS. Only the unmodified form of S92H elF4E was detected, suggesting that Ser92 plays a critical role in the interaction between elF4E and compound 9. 
a

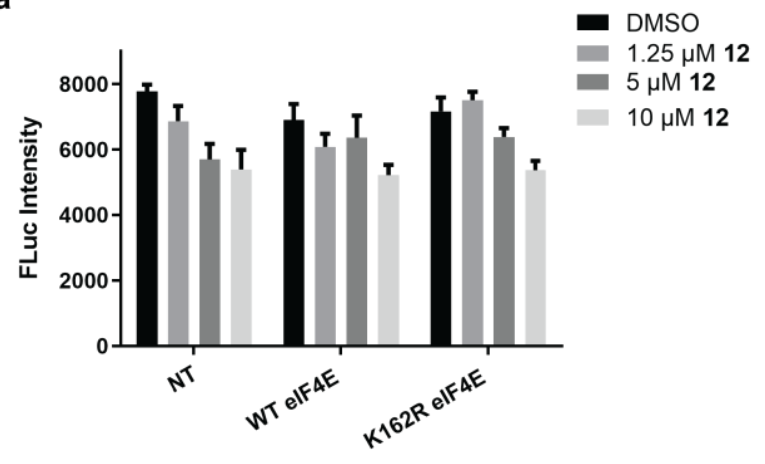

b

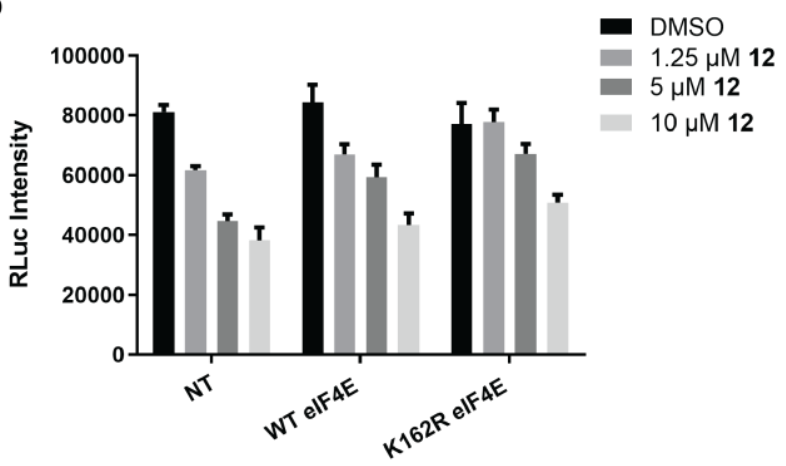

Figure S9. Absolute intensity values from (a) firefly and (b) Renilla luciferase assays, related to Figure $3 c$ (means $\pm S E M, n=3$ ). 


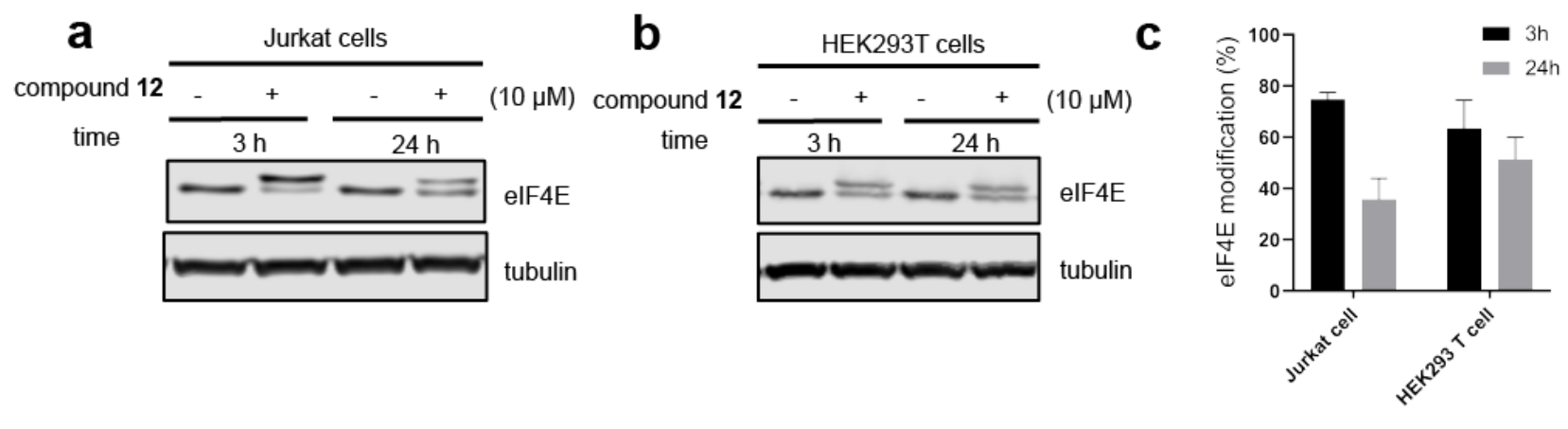

Figure S10. Time-dependent decrease of covalently modified elF4E in cells. (a) Jurkat cells and (b) HEK293T cells were treated with 12 in media containing 10\% FBS. At the indicated time point, cell lysates were prepared and analyzed by Western blotting. (c) The percentage of 12modified elF4E (indicated by gel shift to higher apparent MW) was quantified from (a) and (b) (means $\pm \mathrm{SD}, \mathrm{n}=2$ ). 
a

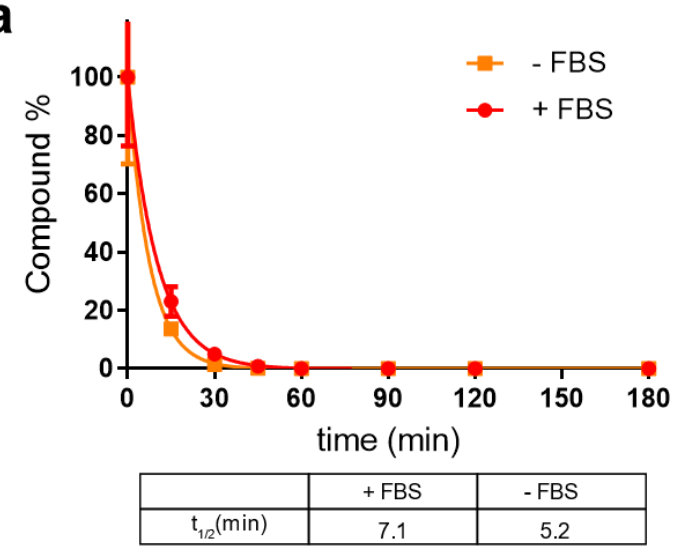

C

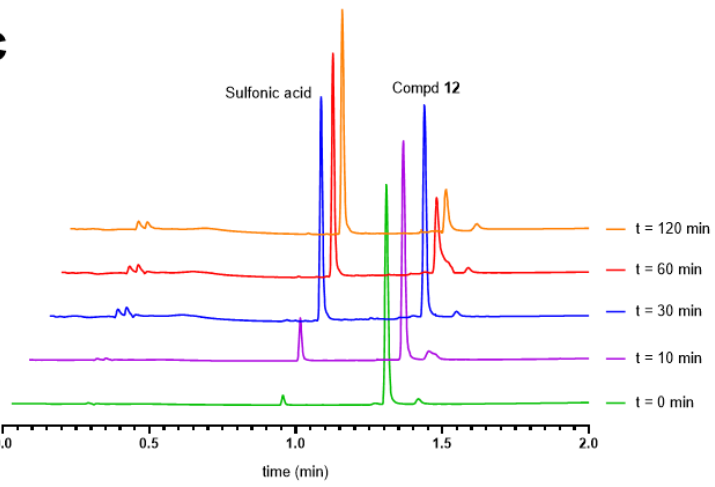

b
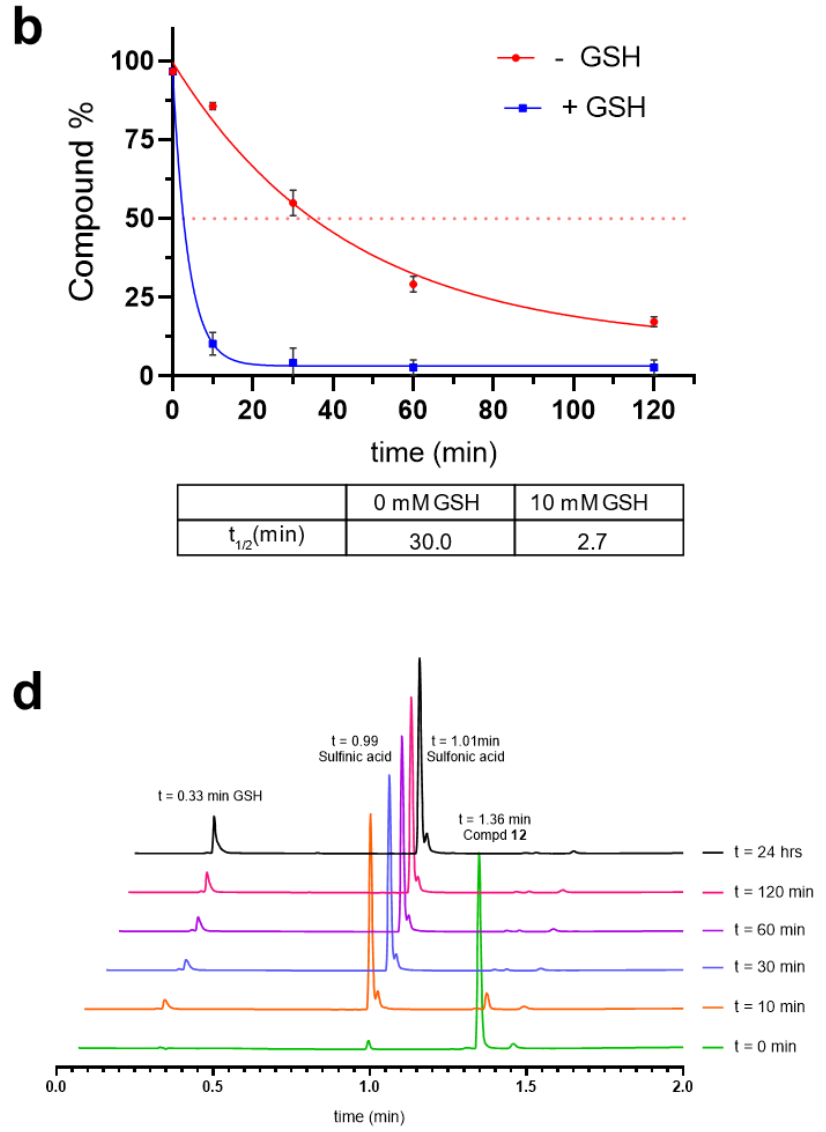

Figure S11. Chemical stability of compound 12. (a) Compound $12(5 \mu \mathrm{M})$ was incubated in cell culture media (DMEM $\pm 10 \% \mathrm{FBS}, 37^{\circ} \mathrm{C}$ ) and monitored by LC-MS (single reaction monitoring). (b-d) Compound $12(500 \mu \mathrm{M})$ was incubated in PBS buffer ( $\mathrm{pH} 7.5,5 \%$ DMSO, 20\% acetonitrile, $\pm 10 \mathrm{mM} \mathrm{GSH}$ ) and monitored by LC-MS. Shown at each time point in (a) and (b) is the percent 12 remaining (means \pm SD, duplicate samples). (c) In PBS buffer (no GSH), compound 12 was hydrolyzed to the corresponding sulfonic acid, as revealed by LC-MS analysis. (d) In PBS buffer with $10 \mathrm{mM} \mathrm{GSH}$, compound 12 was rapidly reduced to the corresponding sulfinic acid. 
Table S3. X-ray data collection and refinement statistics.

\begin{tabular}{|c|c|c|}
\hline PDB ID & $6 \mathrm{U} 06$ & $6 \cup 09$ \\
\hline Compound & 8 & 9 \\
\hline Space group & P1 & P1 \\
\hline \multicolumn{3}{|l|}{ Cell dimensions } \\
\hline$a, b, c(\AA)$ & \begin{tabular}{|l|}
38.11 \\
38.29 \\
146.82
\end{tabular} & $\begin{array}{l}38.1 \\
38.24 \\
147.79\end{array}$ \\
\hline$\alpha, \beta, \gamma(\stackrel{\circ}{\circ})$ & \begin{tabular}{|l|}
87.96 \\
94.87 \\
101.64
\end{tabular} & $\begin{array}{l}95.5 \\
87.28 \\
101.85\end{array}$ \\
\hline Wavelength $(\AA)$ & 1.11685 & 1.12011 \\
\hline Resolution range $(\AA)^{a}$ & $\begin{array}{l}146.21-1.78 \\
(1.86-1.78)\end{array}$ & $\begin{array}{l}146.99-1.68 \\
(1.74-1.68)\end{array}$ \\
\hline Unique reflections & 174072 & 209785 \\
\hline Multiplicity & $\begin{array}{l}2.8 \\
(2.7) \\
\end{array}$ & $\begin{array}{l}3.3 \\
(3.2)\end{array}$ \\
\hline$/ / \sigma$ & $\begin{array}{l}3.0 \\
(1.3) \\
\end{array}$ & $\begin{array}{l}6.0 \\
(1.0)\end{array}$ \\
\hline Completeness (\%) & $\begin{array}{c}95.89 \\
(92.4)\end{array}$ & $\begin{array}{l}97.40 \\
(93.7)\end{array}$ \\
\hline$R_{\text {merge }}{ }^{b}$ & $0.106(0.583)$ & $0.069(0.798)$ \\
\hline $\mathrm{CC}_{1 / 2}(\%)$ & $0.988(0.467)$ & $0.999(0.537)$ \\
\hline \multicolumn{3}{|l|}{ Structure refinement } \\
\hline Resolution range $(\AA)$ & $50.0-1.96(2.03-1.96)$ & $73.53-1.79(1.854-1.79)$ \\
\hline No. reflections & $55811(5583)$ & 71798 (7033) \\
\hline$R_{\text {work }}{ }^{\mathrm{c}}$ & $0.2102(0.2755)$ & $0.1962(0.3266)$ \\
\hline$R_{\text {free }}{ }^{\mathrm{d}}$ & $0.2490(0.3104)$ & $0.2387(0.3694)$ \\
\hline Average $B$ factor $\left(\dot{A}^{2}\right)$ & 49.60 & 41.10 \\
\hline Rmsd bond length $(\dot{A})$ & 0.014 & 0.017 \\
\hline Rmsd bond angles $(\stackrel{\circ}{)}$ & 1.87 & 1.62 \\
\hline \multicolumn{3}{|l|}{ PROCHECK statistics $^{e}$} \\
\hline Ramachandran favored (\%) & 98 & 98 \\
\hline Ramachandran outliers (\%) & 0 & 0 \\
\hline
\end{tabular}

$a_{V a l u e s}$ in parentheses are for the data in the highest resolution shell.

${ }^{b} R_{\text {merge }}=\sum\left|l_{i}-l_{m}\right| / \sum l_{i}$, where $l_{i}$ is the intensity of the measured reflection and $l_{\mathrm{m}}$ is the mean intensity of all symmetry-related reflections.

${ }^{\mathrm{c}} R_{\text {work }}=\Sigma \mid F_{O}-F_{C} / \Sigma F_{O}$, where $F_{O}$ and $F_{C}$ are the observed and calculated structure factor amplitudes.

$\mathrm{d}_{R_{\text {free }}}$ is the same as $R_{\text {work, }}$, but calculated on $5 \%$ of the reflections not used in refinement.

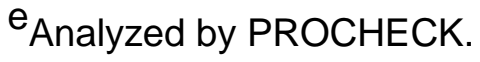




\section{General materials and methods}

\section{Retrospective test of covalent docking to lysine}

To test our covalent docking protocol in the context of the pose prediction, we generated a benchmark set, which contains 16 crystal structures containing lysine-targeted covalent inhibitors. We used the advanced search interface in the PDB website by defining the link connection method (covalent bond), the component (Lys), as well as the atom label type (atom NZ). After removing ions and other native ligands (such as ATP, GTP, etc.), we identified 16 structures from the PDB. The electron density maps of these 16 covalent complexes were manually checked, especially in the region of the covalently modified lysine.

\section{Lysine rotamer sampling}

For the retrospective docking study (Table S1), we first removed the ligand and the side chain atoms of the modified lysine. We then modeled the reactive lysine side chain by sampling rotamers from the Penultimate Rotamer Library ${ }^{1}$ using Chimera. ${ }^{2}$ These sampled (predicted) rotamers were checked for steric clashes with other residues in the binding site. Any rotamers with steric clashes were discarded.

In the prospective study, two crystal structures (PDB ID 4DT6) and (PDB ID 4DUM) were used for docking. The 27 predicted new Lys rotamers (see above), as well as the one from the crystal structures, were checked for steric clashes with other residues in the binding site. Again, rotamers with steric clashes were discarded.

\section{Computational workflow of covalent docking screen}

We used DOCKovalent as implemented in DOCK 3.7.3,4 For pose reproduction analysis, the sampling parameters of covalent bond length and angle were set according to the value from crystal structures. The bump_rigid and bump_maximum were set to the maximum values and check_clashes was changed from 'yes' to 'no' to improve pose sampling by allowing several steric clashes between protein and ligand. The number_save and number_write were modified from 1 to 1000 to keep multiple poses for further analysis. Blastermaster.py was used to prepare docking systems, and the parameter margin was changed from the default value of $10 \AA$ to $6 \AA$ for grid generation. The lysine is immobile during the covalent docking, and a separate screen was carried out for each predicted lysine rotamer. Each conformation of the sampled compound was scored and ranked according to the physics-based scoring function in DOCK3.7 without considering the different conformational energies among the lysine rotamers.

For the prospective study, the covalent bond parameters were set to a length of $1.61 \AA$ and two newly formed angles to CE-N-S $=121 \pm 5^{\circ}$ and N-S-lig atom $=107.4 \pm 5^{\circ}$ based on previous crystal structures of a lysine-targeted sulfonyl fluoride. ${ }^{5}$

\section{Post-docking pose analysis}

Retrospective docking study: RMSD values for the ligand heavy atoms between the top-scoring pose and the crystal structure were calculated using an in-house script. For each ligand, the pose with the lowest RMSD out of the top 1,000-scoring poses was saved for minimization refinement, and a second (post-minimization) RMSD was calculated. 
For the primary docking screen of elF4E, the top-scoring $219(0.24 \%)$ molecules were inspected both for forming key hydrogen-bonding interactions, and for potential internal energy strain in the ligand. While both terms are addressed in docking--by favorable ligand interactions with protein electrostatic potential, and by the generation of putatively low-energy ligand conformations--here we used secondary criteria, distance-based formation of particular hydrogen bonds, and lack of visible torsional and internal electrostatic strain in the ligand geometries. The best 1000 poses for each of the top-scoring ligands were filtered (using automated scripts; see below) for those with hydrogen bonds to the side chain of Glu103 and the backbone $\mathrm{NH}$ of Trp102 (Figure 1c). Compounds that formed these interactions but did not form pi-stacking interactions with Trp56 and Trp102 were removed. In addition, we deprioritized any remaining ligands that displayed strained torsional angles or unfavorable internal electrostatic interactions. For the secondary docking screen, our inclusion criteria also required compounds to occupy the hydrophobic binding pocket (within $5 \AA$ of Phe48, Leu60, and Val153). We combined all compounds from docking to each of the selected lysine rotamers and ranked them from most to least favorable score. Finally, the top-scoring pose for each compound was selected for minimization.

\section{Molecular mechanics-based minimization and MM-GB/SA calculation}

We further optimized the geometry of the protein-ligand adducts by energy minimization ${ }^{6}$ using AMBER $14 .{ }^{7}$ The Antechamber module was used to calculate partial charges using the semiempirical AM1-BCC method to assign force field parameters and to calculate topology files for the ligand. These files were modified to create a covalent adduct by combining the ligand topology and attached lysine residue. Parameters for the covalent linkage between ligands and Lys residue were assigned by mixing generalized amber force field (GAFF) ${ }^{8}$ parameters for the ligand and the Amber force field for the protein. These parameters, located at the borderline between the two force fields, were assigned on the basis of the analogous parameters available for similar atom types. TLeap was then used to prepare the complex generated from docking for molecular mechanics. We used the sander program to minimize the covalent system. 5,000 steps of minimization were carried out using the Hawkins, Cramer, Truhlar pairwise generalized Born model with harmonic position restraints on all heavy atoms except for the ligand and the attached lysine residue. For the modeling of compound 12, Glu103 was allowed to vary. Snapshots of the receptor, ligand, and receptor-ligand complex (final snapshot after minimization) were analyzed and the binding free energy was calculated by using the molecular mechanics/generalized Born surface area (MM/GBSA) method: $\Delta \Delta \mathrm{G}_{\text {bind }}=\Delta \mathrm{G}_{\text {mmgbsa,complex }}$ $\left(\Delta \mathrm{G}_{\mathrm{mmgbsa} \text {,ig }}+\Delta \mathrm{G}_{\mathrm{mmgbsa}, \mathrm{rec}}\right)$, see also:

http://wiki.docking.org/index.php/DOCKovalent lysine inhibitor design tutorial.

Scripts used in this study can be downloaded from the following link:

http://files.docking.org/scripts/2019-11-25-dockcovalent lys scripts.tgz

\section{Virtual library generation}

The primary docking screen of elF4E was carried out using the Enamine REAL sulfonyl fluoride library (https://enamine.net/index.php?option=com content\&task=view\&id=254), which contains 88186 compounds. To generate the library for the secondary docking screen, we searched Enamine's building block catalogue for aryl and heteroaryl aldehydes for virtual parallel synthesis according to the scheme shown in Figure S2a. We selected 2239 aldehyde building 
blocks based on the following criteria: number of rings $\leq 2, \mathrm{MW}$ of the final product $\leq 600$, and building block price $\leq \$ 400 / \mathrm{g}$. All pre-generated ligand conformations were built in the reacted form represented by a dummy silicon atom. ${ }^{9}$ Protonated and tautomerized conformations were generated by Corina (https://www.mn-am.com/products/corina). The new hierarchy format of the ligand flexibase (mol2db2) was used for covalent docking. ${ }^{10}$

\section{Protein expression and purification}

Murine elF4E (residues 28-217, E174D) and full-length human WT, K162R, and S92H elF4E were cloned into a modified pHMGWA plasmid with a MBP-His tag and PreScission protease cleavage site. Covalent labeling assays were performed with full-length human elF4E. Murine elF4E (residues 28-217, E174D) was used for crystallization. Protein expression and purification was carried out as previously described. ${ }^{11}$ Purified elF4E was stored in gel filtration buffer (20 mM HEPES pH 7.2, $100 \mathrm{mM} \mathrm{KCl}$, and 0.5 mM EDTA).

\section{LC-MS analysis of elF4E modification}

Full-length human elF4E (WT or K162R, $1 \mu \mathrm{M})$ was treated with compounds 1-7 (100 $\mu \mathrm{M})$ in $100 \mathrm{mM}$ HEPES pH 8.1, $150 \mathrm{mM} \mathrm{KCl}$ (labeling buffer) at room temperature (RT) for $3 \mathrm{~h}$.

Compounds 8, 9, 13-15 were tested at $50 \mu \mathrm{M}$ using the same buffer (100 mM HEPES pH $8.1,150 \mathrm{mM} \mathrm{KCl})$.

WT elF4E $(0.5 \mu \mathrm{M})$ was treated with increasing concentrations of 9 and 10 at RT for $1 \mathrm{~h}$ in labeling buffer (100 mM HEPES pH 8.1, $150 \mathrm{mM} \mathrm{KCl}$ ). In a separate experiment, WT elF4E $(0.5 \mu \mathrm{M})$ was treated with increasing concentrations of $\mathbf{1 0 - 1 2}$ at $\mathrm{RT}$ for $15 \mathrm{~min}$ in $\mathrm{pH} 7.0$ labeling buffer (100 mM HEPES, $150 \mathrm{mM} \mathrm{KCl}$ ). Samples were then analyzed by intact-protein LC-MS as described below.

For determination of $\mathrm{K}_{\mathrm{i}}$ and $\mathrm{k}_{\text {inact }}$, elF4E $(0.5 \mu \mathrm{M})$ was treated with compounds 10-12 (0.1-200 $\mu \mathrm{M})$ at $\mathrm{RT}$ in $\mathrm{pH} 8.1$ labeling buffer. At each time point, an aliquot was quenched with formic acid ( $1 \%$ final concentration) and analyzed on a Waters Xevo G2-XS QToF LC-MS. LC-MS runs were auto-processed using the Waters OpenLynx software. Deconvolution of the charge envelope between 800 and $1600 \mathrm{~m} / \mathrm{z}$ was performed using MaxEnt to determine the monoisotopic mass of unlabeled and compound-labeled elF4E using a target mass range of 22000-28000 Da and a mass resolution of $1 \mathrm{Da}$. The percentage of labeled elF4E (derived from integrating the monoisotopic mass peaks) was plotted as a function of time (means $\pm S D$, duplicate samples) and fit to a single phase exponential association curve (constrained to a plateau of $100 \%$ and an initial value of $0 \%$ ) to derive $k_{o b s}$, which was plotted vs. compound concentration and fit to the Michaelis-Menten equation to yield the final kinetic parameters $k_{\text {inact }}$ and $\mathrm{K}_{\mathrm{i}}$ (Prism 8, GraphPad).

\section{LC-MS/MS analysis of elF4E modification by compound 9}

WT elF4E $(1 \mu \mathrm{M})$ was treated with compound $9(50 \mu \mathrm{M})$ in labeling buffer $(100 \mathrm{mM} \mathrm{HEPES} \mathrm{pH}$ $8.1,150 \mathrm{mM} \mathrm{KCl})$ at RT for 6 or $24 \mathrm{~h}$. The sample was reduced with $5 \mathrm{mM}$ DTT at $56^{\circ} \mathrm{C}$ for 30 min, followed by alkylation with $20 \mathrm{mM}$ iodoacetamide in the dark for $15 \mathrm{~min}$. After quenching unreacted iodoacetamide with another $5 \mathrm{mM}$ DTT, $1 \mu \mathrm{g}$ sequencing grade trypsin (Promega) was added and the mixture was incubated at $37^{\circ} \mathrm{C}$ overnight. Digestion was stopped by adding $2 \%$ formic acid. The resulting peptides were desalted with C18 OMIX tips (Agilent) $(50 \%$ $\mathrm{MeCN} / 0.1 \%$ formic acid elution), dried down, and resuspended in $0.1 \%$ formic acid. Peptides 
were analyzed by LC-MS/MS using a Nano-Acquity Ultra Performance UPLC system (Waters) connected to a LTQ-Orbitrap Velos (Thermo Fisher Scientific). An EASY-Spray PepMap RSLC C18, $3 \mu \mathrm{m}, 75 \mu \mathrm{m} \times 15 \mathrm{~cm}$ column (Thermo Scientific) was used to resolve peptides $(0.1 \%$ formic acid in water as mobile phase $A$ and $0.1 \%$ formic acid in acetonitrile as mobile phase B). 90-min LC gradients were set as follows: load at $2 \% \mathrm{~B}$ at $600 \mathrm{~nL} / \mathrm{min}$ for $18 \mathrm{~min}$, reduce flow rate to $300 \mathrm{~nL} / \mathrm{min}$ over $2 \mathrm{~min}$, gradient from 2 to $30 \%$ B over $57 \mathrm{~min}$, increase to $50 \%$ B over 2 min, decrease to $2 \%$ B over 2 min, and equilibrate at $2 \%$ B for 9 min.

The LTQ-Orbitrap Velos was operated in data-dependent mode (full MS resolution, 30000) to automatically switch between MS and MS/MS. The top six precursor ions with a charge state of $2+$ or higher were selected with an isolation width of $3.0 \mathrm{~m} / \mathrm{z}$ and fragmented by CID, using a dynamic exclusion time of $60.0 \mathrm{~s}$. Raw files were analyzed using Protein Prospector (6.1.0). Database was set to SwissProt.2019.4.8.random.concat; Mass tolerance was set to 20 ppm for Parent Tolerance and 30 ppm for Fragment Tol, respectively; Digestion enzyme was set to trypsin with a maximum of 2 missed cleavages. Constant modification was set to carbamidomethyl $(\mathrm{C})$; variable modifications were set to oxidation (M), acetyl (protein N-term), and compound 9 addition (453.0453 Da) to $\mathrm{K}$ or $\mathrm{Y}$; FDR was set to $5 \%$ at the protein level and $1 \%$ at the peptide level.

\section{Protein crystallization and structure determination}

Covalent modification of elF4E $(1 \mu \mathrm{M})$ by 8 and $9(20 \mu \mathrm{M})$ in labeling buffer $(100 \mathrm{mM} \mathrm{HEPES} \mathrm{pH}$ $8.1,150 \mathrm{mM} \mathrm{KCl}$ ) was confirmed by LC-MS before crystallization. The covalent elF4E complex was then exchanged into gel filtration buffer $(20 \mathrm{mM}$ HEPES pH 7.2, $100 \mathrm{mM} \mathrm{KCl}, 0.5 \mathrm{mM}$ EDTA) by ultrafiltration ( $10 \mathrm{kDa}$ MWCO, Millipore Amicon Ultra) and concentrated to 4 4.5 $\mathrm{mg} / \mathrm{mL}$. Crystallization was performed via the hanging drop method, with a 1:1 mixture of elF4E adduct and the precipitation solution $(450 \mu \mathrm{L}$ of $0.1 \mathrm{M}$ HEPES $7.5 \mathrm{pH}, 5 \% \mathrm{v} / \mathrm{v} \mathrm{MPD}, 10 \% \mathrm{w} / \mathrm{v}$ PEG 6000 with $50 \mu \mathrm{L}$ of $1.0 \mathrm{M}$ NDSB-256 from Hampton additive screening). Protein crystals formed within 2-3 days at RT.

Crystals were cryoprotected in the precipitation solution supplemented with $20 \%$ glycerol and stored in liquid nitrogen. Diffraction data were collected at Beamline 8.3.1 of the Advanced Light Source (ALS, Lawrence Berkeley National Laboratory). An automated script of XDS package ${ }^{12}$ was used to index, integrate and scale the reflections. Molecular replacement was performed with Phenix ${ }^{13}$ (PDB ID: 4DT6 as template). Initial model building was performed manually with Coot $^{14}$ and further refined with REFMAC ${ }^{15}$ in the CCP4 suite. ${ }^{16}$

\section{m7GTP-agarose pulldown assay}

Jurkat cells (8e6 per condition) were treated with compounds 9-11 (10 $\mu \mathrm{M})$ or $12(0.04-10 \mu \mathrm{M})$ at $37^{\circ} \mathrm{C}$. After $3 \mathrm{~h}$, the cells were washed with ice-cold PBS and extracted with $500 \mu \mathrm{L}$ lysis buffer (100 mM HEPES pH 8.1, 150 mM KCI, 0.1\% NP-40, 2 mM PMSF, protease and phosphatase inhibitor cocktails). Protein concentrations were normalized by BCA, and an aliquot of each sample was analyzed by Western blotting for elF4E and tubulin ("lysates"). Remaining lysate samples were enriched with m7GTP-agarose beads (65 $\mu \mathrm{L}$, Jena Biosciences, AC-155) overnight at $4^{\circ} \mathrm{C}$. After washing 5 times with PBS, bound proteins were eluted with $2 x$ SDS loading buffer, heated at $95^{\circ} \mathrm{C}$ for $5 \mathrm{~min}$, and analyzed by Western blotting for elF4E. 


\section{Flag-elF4E stable cell lines}

WT and K162R elF4E coding sequences were inserted by Gibson assembly ${ }^{17}$ into a pHR lentiviral vector containing an eEF1A promoter, 3xFlag tag, and IRES-GFP. Lentiviral particles were generated as described previously. ${ }^{18}$ Briefly, HEK293T packaging cells in 6-well plates were transfected with 3xFlag-eIF4E-IRES-GFP, 2nd-generation packaging plasmid pCMVdR8.91, and envelope plasmid pMD2.G using TransIT-LT1 transfection reagent (Mirus Bio, Madison, WI) according to the manufacturer's instructions. Virus-containing media was collected after 48 and $72 \mathrm{~h}$ and used for infections without further processing. HEK293T cells at $70 \%$ confluence in $6 \mathrm{~cm}$ dishes were treated with polybrene $(8 \mu \mathrm{g} / \mathrm{mL}$, AmericanBio, Natick, MA) and lentivirus. After $24 \mathrm{~h}$, cells were trypsinized and passaged in complete growth media. GFPpositive cells overexpressing WT and K162R elF4E were sorted by flow cytometry (BD FACSAria II) in FACS buffer (PBS+2\% FBS + 2 mM EDTA) and propagated.

\section{Western blotting}

Gels were transferred to $0.2 \mu \mathrm{M}$ nitrocellulose membranes (Bio-Rad, 162-0112), blocked with $5 \%$ nonfat milk, incubated with primary antibody overnight at $4^{\circ} \mathrm{C}$. Antibodies: anti-eIF4E antibody (Novus Biologicals, cat. 299910), anti-Flag (Sigma, cat. F3165) and anti-a-Tubulin antibody (Sigma, cat. T9026). The final signal was detected with goat anti-mouse light chainspecific secondary antibody conjugated to $800 \mathrm{~nm}$ near-IR dye (Jackson ImmunoResearch Laboratories, West Grove, PA). Blots were scanned on an Odyssey infrared imager (LI-COR Biosciences).

\section{Dual luciferase reporter assay}

The bicistronic reporter plasmid ${ }^{19}$ (obtained from Addgene, cat. 45642) comprises a capdependent cistron (Renilla luciferase), followed by a poliovirus internal ribosome entry site driving a cap-independent cistron (firefly luciferase). The plasmid was purified with the Plasmid Plus kit (QIAGEN) according to the manufacturer's instructions. HEK293T cells stably overexpressing WT or K162R FLAG-elF4E, or nontransduced cells (NT), were seeded at 200,000 cells/well in 24-well plates for 16-24 h. Cells were treated with compound $12(1.25 \mu \mathrm{M}$ and $5 \mu \mathrm{M}$ ) after changing to fresh media (DMEM, 10\% FBS). Plasmid transfection was carried out with Lipofectamine LTX with PLUS reagent according to the manufacturer's instructions; 100 $\mu \mathrm{L}$ transfection mix was added to each well $(1 \mu \mathrm{g}$ plasmid, $1 \mu \mathrm{L}$ Plus Reagent, $2 \mu \mathrm{L} \mathrm{LTX}$ reagent in OptiMem media). Cells were further incubated for $6 \mathrm{~h}$ in the presence of compound prior to analyzing luciferase levels using the dual luciferase assay system (Promega) according to the manufacturer's instructions. Relative luciferase signal from triplicates was background subtracted and normalized to DMSO-treated controls prior to data analysis and plotting in Prism 8 (GraphPad).

\section{Determination of compound stability by LC-MS}

Compound 12 stability was assessed in DMEM $\pm 10 \%$ FBS using liquid chromatography-tandem mass spectrometry (LC-MS/MS) analysis with selected reaction monitoring (SRM).$^{20}$ Reactions were initiated by the addition of $10 \mu \mathrm{L}$ compound $12(0.5 \mathrm{mM})$ to $1 \mathrm{~mL}$ of media solution to yield a final concentration of $5 \mu \mathrm{M}\left(37^{\circ} \mathrm{C}\right.$, duplicate samples). Aliquots $(100 \mu \mathrm{L})$ were removed at the 
indicated time points and added to $100 \mu \mathrm{L}$ acetonitrile/0.2\% formic acid. After vortex mixing for $10 \mathrm{~s}$ and centrifugation at $4^{\circ} \mathrm{C}$ for $5 \mathrm{~min}$ at $14,000 \mathrm{rpm}$, supernatants were analyzed on a Waters Xevo G2-XS QToF LC-MS. Optimal collision energy for fragmentation was found to be $40 \mathrm{~V}$. The retention time for compound 12 was 1.32 min and two MS2 fragments (MW 203.1 and 314.1) were used for SRM quantitation. The percentage of 12 remaining vs. time was plotted and analyzed in Prism 8 (GraphPad).

Compound $12(500 \mu \mathrm{M})$ and its decomposition products were also monitored in PBS buffer $(\mathrm{pH}$ $7.5,5 \% \mathrm{DMSO}, 20 \%$ acetonitrile, $\pm 10 \mathrm{mM} \mathrm{GSH}$ ) at $37^{\circ} \mathrm{C}$. At the indicated time points, an aliquot was diluted $1: 1$ with $0.1 \%$ formic acid/MeCN and analyzed by LC-MS.

\section{Compound synthesis and characterization}

NMR spectra were recorded on a Varian spectrometer at $400 \mathrm{MHz}$ or on a Bruker spectrometer at $500 \mathrm{MHz}$. Chemical shifts were reported as parts per million (ppm) from an internal tetramethylsilane standard or solvent references. LC-MS was performed on a Waters LC system coupled with Xevo G2-XS QTof Mass Spectrometer with a flow rate of $0.2 \mathrm{~mL} / \mathrm{min}$ using an Xterra MS C18 column (Waters) with water-acetonitrile gradient containing $0.1 \%$ formic acid. All other solvents were of ACS chemical grade (Fisher Scientific) and used without further purification. Commercially available reagents were used without further purification. Analytical thin-layer chromatography was performed with silica gel 60 F254 glass plates (EM Science). Silica gel chromatography was performed with 230-400 mesh silica gel (Selecto Scientific).<smiles>[R]Nc1nc2ccc(N)cc2c(=O)[nH]1</smiles><smiles>[R]Nc1nc2ccc(NS(=O)(=O)c3cccc([Se])c3)cc2c(=O)[nH]1</smiles>

$$
\begin{aligned}
& R=H, \quad \text { iii } \\
& R=M e, ~ i v ~
\end{aligned}
$$<smiles>[R]Nc1nc2ccc(N(Cc3ccnc(Cl)c3)S(=O)(=O)c3cccc(S(=O)(=O)F)c3)cc2c(=O)[nH]1</smiles>

$\mathrm{R}=\mathrm{H}, \quad 11$

$\mathrm{R}=\mathrm{Me}, 12$

Scheme S1. Chemical synthesis of compounds 11 and 12. 
<smiles>CNc1nc2ccc([N+](=O)[O-])cc2c(=O)[nH]1</smiles>

Compound i. To a mixture of $\mathrm{MeCN}$ and $\mathrm{H}_{2} \mathrm{O}(4: 1,12 \mathrm{~mL})$ were added 1.5-nitroisatoic anhydride $(1.7 \mathrm{~g}, 7.84 \mathrm{mmol})$ and $1,2-$

dimethylisothiourea hydriodate $(1.86 \mathrm{~g}, 7.84 \mathrm{mmol})$ followed by sodium carbonate $(1.66 \mathrm{~g}, 15.68 \mathrm{mmol})$. The mixture was heated to reflux for 6 $\mathrm{h}$ before being concentrated under vacuum. The resulting solid was washed with water, and compound $\mathbf{i}(1.07 \mathrm{~g}, 4.86 \mathrm{mmol}, 62 \%$ yield) was obtained as a white solid after silica gel chromatography $\left(0-20 \% \mathrm{MeOH}\right.$ in DCM). ${ }^{1} \mathrm{H}$ NMR (400 MHz, DMSO) $\delta 11.53(\mathrm{~s}, 1 \mathrm{H}), 8.62(\mathrm{~d}, J=2.7 \mathrm{~Hz}, 1 \mathrm{H}), 8.30$ (dd, $J=9.1,2.8 \mathrm{~Hz}, 1 \mathrm{H}), 7.35$ (d, J $=9.1 \mathrm{~Hz}, 1 \mathrm{H}), 6.78(\mathrm{~s}, 1 \mathrm{H}), 2.90(\mathrm{~d}, J=4.7 \mathrm{~Hz}, 3 \mathrm{H}), 2.08(\mathrm{~s}, 3 \mathrm{H}) \cdot{ }^{13} \mathrm{C}$ NMR $(100 \mathrm{MHz}, \mathrm{DMSO}) \delta$ 206.97, 161.64, 156.80, 153.80, 141.12, 128.84, 126.03, 123.16, 117.00, 31.17, 28.13. HRMS calculated $\mathrm{m} / \mathrm{z}$ for $\mathrm{C} 9 \mathrm{H} 9 \mathrm{~N} 4 \mathrm{O} 3\left(\mathrm{M}+\mathrm{H}^{+}\right)$: 221.0669; found: 221.0706 .<smiles>CNc1nc2ccc(N)cc2c(=O)[nH]1</smiles>

Compound ii. Compound i (150 mg, $0.68 \mathrm{mmol}$ ) was dissolved in $\mathrm{EtOH}$ $(2 \mathrm{~mL})$, to which was added aqueous $1 \mathrm{M} \mathrm{HCl}(0.75 \mathrm{~mL})$ and iron powder (114 mg. $2.04 \mathrm{mmol})$. The mixture was heated to reflux for $1 \mathrm{~h}$. Then the reaction was cooled to $\mathrm{RT}$ and quenched with aqueous ammonia hydroxide solution ( $20 \% \mathrm{v} / \mathrm{v}, 2 \mathrm{~mL})$. The suspension was filtered through a pad of Celite, and the filtrate was concentrated under vacuum to give compound ii (130 $\mathrm{mg}, 0.68 \mathrm{mmol}, 100 \%$ yield) as a yellow solid, which was used for next step without further purification. ${ }^{1} \mathrm{H}$ NMR (400 MHz, DMSO) $\delta 7.30(\mathrm{~s}, 1 \mathrm{H}), 7.23-$ $7.13(\mathrm{~m}, 2 \mathrm{H}), 7.09(\mathrm{~s}, 1 \mathrm{H}), 7.05(\mathrm{~s}, 1 \mathrm{H}), 7.00-6.91(\mathrm{~m}, 1 \mathrm{H}), 6.51(\mathrm{~s}, 1 \mathrm{H}), 2.84(\mathrm{~s}, 3 \mathrm{H})$. HRMS calculated $\mathrm{m} / \mathrm{z}$ for $\mathrm{C} 9 \mathrm{H} 11 \mathrm{~N} 4 \mathrm{O}\left(\mathrm{M}+\mathrm{H}^{+}\right)$: 191.0927 ; found: 191.0949 .<smiles>Nc1nc2ccc(NS(=O)(=O)c3cccc(S(=O)(=O)F)c3)cc2c(=O)[nH]1</smiles>

Compound iii. To a suspension of 2,6-diamino-4hydroxyquinazoline $(50 \mathrm{mg}, 0.28 \mathrm{mmol})$ in a mixture of DMF and pyridine $(1: 1,2 \mathrm{~mL})$ was added 3(chlorosulfonyl)benzenesulfonyl fluoride $(81 \mathrm{mg}, 0.31$ $\mathrm{mmol}$ ) at $4^{\circ} \mathrm{C}$. The reaction was warmed to RT and stirred overnight. The reaction solution was poured into water $(10 \mathrm{~mL})$ and extracted with ethyl acetate $(10 \mathrm{~mL} \times 3)$. The organic fractions were pooled, dried over $\mathrm{Na}_{2} \mathrm{SO}_{4}$, and concentrated under vacuum. Compound iii (12 mg, $0.03 \mathrm{mmol}, 10 \%$ yield) was obtained as a yellow solid after silica gel chromatography $\left(0-20 \% \mathrm{MeOH}\right.$ in DCM). ${ }^{1} \mathrm{H} \mathrm{NMR}$ (400 MHz, DMSO) $\delta 10.99(\mathrm{~s}, 1 \mathrm{H}), 10.42(\mathrm{~s}, 1 \mathrm{H}), 8.40(\mathrm{~d}, J=8.0 \mathrm{~Hz}, 1 \mathrm{H}), 8.26(\mathrm{t}, J=1.7 \mathrm{~Hz}$, $1 \mathrm{H}), 8.14(\mathrm{~d}, J=8.2 \mathrm{~Hz}, 1 \mathrm{H}), 7.96(\mathrm{t}, J=7.9 \mathrm{~Hz}, 1 \mathrm{H}), 7.50(\mathrm{~d}, J=2.6 \mathrm{~Hz}, 1 \mathrm{H}), 7.28$ (dd, $J=8.8$, $2.6 \mathrm{~Hz}, 1 \mathrm{H}), 7.11(\mathrm{~d}, J=8.8 \mathrm{~Hz}, 1 \mathrm{H}), 6.35(\mathrm{~s}, 2 \mathrm{H}) .{ }^{19} \mathrm{~F}$ NMR $\left(376 \mathrm{MHz}\right.$, DMSO) $\delta 66.70(\mathrm{~s}) .{ }^{13} \mathrm{C}$ NMR (126 MHz, DMSO) $\delta ~ 161.62,151.61,149.46,140.96,134.22,132.61,133.53$ (d, J = 24.6 $\mathrm{Hz}), 132.24,129.98,129.39,126.18,125.36,119.05,117.30$. HRMS calculated $\mathrm{m} / \mathrm{z}$ for C14H12FN4O5S2 $\left(\mathrm{M}+\mathrm{H}^{+}\right)$: 399.0228; found: 399.0226 .

Compound iv. To a solution of compound ii (30 mg, $0.16 \mathrm{mmol})$ in DMF (1 mL) was added 3(chlorosulfonyl)benzenesulfonyl fluoride ( $45 \mathrm{mg}, 0.17 \mathrm{mmol}$ ) followed by sodium carbonate (50 $\mathrm{mg}, 0.47 \mathrm{mmol})$. After stirring at RT for $3 \mathrm{~h}$, the reaction mixture was poured into water $(10 \mathrm{~mL})$ and extracted with ethyl acetate $(10 \mathrm{~mL} \times 3)$. The organic extracts were pooled, dried over $\mathrm{Na}_{2} \mathrm{SO}_{4}$, and concentrated under vacuum. Compound iv (18 mg, $0.44 \mathrm{mmol}, 28 \%$ yield) was 
<smiles>CNc1nc2ccc(NS(=O)(=O)c3cccc(S(=O)(=O)F)c3)cc2c(=O)[nH]1</smiles>

obtained as a yellow solid after silica gel chromatography $\left(0-20 \% \mathrm{MeOH}\right.$ in DCM). ${ }^{1} \mathrm{H}$ NMR (400 MHz, DMSO) $\delta$

$11.06(\mathrm{~s}, 1 \mathrm{H}), 10.44(\mathrm{~s}, 1 \mathrm{H}), 8.39(\mathrm{~d}, J=8.0 \mathrm{~Hz}, 1 \mathrm{H}), 8.26$ (s, $1 \mathrm{H}), 8.14(\mathrm{~d}, J=6.5 \mathrm{~Hz}, 2 \mathrm{H}), 7.96(\mathrm{t}, J=8.0 \mathrm{~Hz}, 1 \mathrm{H})$, $7.51(\mathrm{~d}, J=2.5 \mathrm{~Hz}, 1 \mathrm{H}), 7.28$ (dd, $J=8.8,2.6 \mathrm{~Hz}, 1 \mathrm{H})$, $7.18(\mathrm{~d}, J=8.8 \mathrm{~Hz}, 1 \mathrm{H}), 6.52(\mathrm{~s}, 1 \mathrm{H}), 6.15(\mathrm{~s}, 1 \mathrm{H}), 2.80$

$(\mathrm{d}, J=4.6 \mathrm{~Hz}, 3 \mathrm{H}) \cdot{ }^{19} \mathrm{~F}$ NMR (376 MHz, DMSO) $\delta 66.68$ (s). ${ }^{13} \mathrm{C}$ NMR (100 MHz, DMSO) $\delta$ 163.06, 161.47, 151.08, 149.01, 140.99, 134.18, 132.56, 132.54 (d, J=25.0 Hz), 132.20, 130.04, 129.25, 126.14, 125.82, 118.92, 117.47, 27.47. HRMS calculated $m / z$ for C15H14FN4O5S2 $\left(\mathrm{M}+\mathrm{H}^{+}\right)$: 413.0384; found: 413.0372.<smiles>Nc1nc2ccc(N(Cc3ccnc(Cl)c3)S(=O)(=O)c3cccc(S(=O)(=O)F)c3)cc2c(=O)[nH]1</smiles>

\section{Compound 11.}

3-(N-(2-amino-4-oxo-3,4-dihydroquinazolin-6-yl)-N-((2chloropyridin-4-yl)methyl)sulfamoyl)benzenesulfonyl fluoride. To a solution of compound iii $(5 \mathrm{mg}, 0.01 \mathrm{mmol})$ in DMF (1 mL) was added 4-(bromomethyl)-2chloropyridine ( $3.1 \mathrm{mg}, 0.2 \mathrm{mmol}$ ) followed by potassium carbonate $(3.47 \mathrm{mg}, 0.03 \mathrm{mmol})$. The mixture was stirred at RT for $2 \mathrm{~h}$ before being concentrated under vacuum. Compound 11 (4.7 mg, $0.009 \mathrm{mmol}, 71 \%$ yield) was obtained as a white solid HPLC purification (5-95\% MeCN in $\mathrm{H}_{2} \mathrm{O}$ ). ${ }^{1} \mathrm{H}$ NMR (400 MHz, DMSO) $\delta 11.21(\mathrm{~s}, 1 \mathrm{H}), 8.54(\mathrm{~d}, J=8.7 \mathrm{~Hz}, 1 \mathrm{H}), 8.37-8.30(\mathrm{~m}, 1 \mathrm{H}), 8.18(\mathrm{~d}, J=8.3 \mathrm{~Hz}, 1 \mathrm{H}), 8.11-$ $8.00(\mathrm{~m}, 2 \mathrm{H}), 7.49(\mathrm{~d}, J=2.6 \mathrm{~Hz}, 1 \mathrm{H}), 7.43-7.35(\mathrm{~m}, 2 \mathrm{H}), 7.31(\mathrm{dd}, J=8.8,2.6 \mathrm{~Hz}, 1 \mathrm{H}), 7.09$ $(\mathrm{d}, J=8.8 \mathrm{~Hz}, 1 \mathrm{H}), 6.59(\mathrm{~s}, 2 \mathrm{H}), 4.95(\mathrm{~s}, 2 \mathrm{H}) .{ }^{19} \mathrm{~F} \mathrm{NMR}(376 \mathrm{MHz}, \mathrm{DMSO}) \delta 66.63$ (s). ${ }^{13} \mathrm{C}$ NMR (100 MHz, DMSO) $\delta 161.46,152.54,151.43,150.42,150.17,149.61,138.71,134.97,134.29$, $133.15,132.73$ (d, $J=25.1 \mathrm{~Hz}$ ), 132.42, 130.90, 126.92, 125.70, 125.13, 123.14, 122.28, 117.20, 52.42. HRMS calculated $\mathrm{m} / \mathrm{z}$ for $\mathrm{C} 20 \mathrm{H} 16 \mathrm{CIFN5O5S2}\left(\mathrm{M}+\mathrm{H}^{+}\right): 524.0260$; found: 524.0280 .<smiles>CNc1nc2ccc(N(Cc3ccnc(Cl)c3)S(=O)(=O)c3cccc(S(=O)(=O)F)c3)cc2c(=O)[nH]1</smiles>

\section{Compound 12.}

3-(N-((2-chloropyridin-4-yl)methyl)-N-(2-(methylamino)-4oxo-3,4-dihydroquinazolin-6-yl)sulfamoyl)benzenesulfonyl fluoride. To a solution of compound iv $(14 \mathrm{mg}, 0.03 \mathrm{mmol})$ in DMF $(1 \mathrm{~mL})$ was added 4-(bromomethyl)-2chloropyridine $(11 \mathrm{mg}, 0.05 \mathrm{mmol})$ followed by potassium carbonate $(9.38 \mathrm{mg}, 0.07 \mathrm{mmol})$. The mixture was stirred at RT for $2 \mathrm{~h}$ before being concentrated under vacuum. Compound 12 (12 mg, $0.02 \mathrm{mmol}, 66 \%$ yield) was obtained as a yellow solid HPLC purification (5-95\% MeCN in $\mathrm{H}_{2} \mathrm{O}$ ). ${ }^{1} \mathrm{H}$ NMR (400 MHz, DMSO) $\delta 11.25(\mathrm{~s}, 1 \mathrm{H}), 8.54(\mathrm{~d}, J=7.9 \mathrm{~Hz}, 1 \mathrm{H}), 8.34(\mathrm{~d}, J=5.1 \mathrm{~Hz}, 1 \mathrm{H}), 8.18(\mathrm{~d}, J=8.1 \mathrm{~Hz}, 1 \mathrm{H}), 8.13$ $-7.96(\mathrm{~m}, 2 \mathrm{H}), 7.50(\mathrm{~d}, J=2.6 \mathrm{~Hz}, 1 \mathrm{H}), 7.44-7.36(\mathrm{~m}, 2 \mathrm{H}), 7.31(\mathrm{dd}, J=8.8,2.6 \mathrm{~Hz}, 1 \mathrm{H}), 7.17$ $(\mathrm{d}, J=8.8 \mathrm{~Hz}, 1 \mathrm{H}), 6.41(\mathrm{~s}, 1 \mathrm{H}), 4.95(\mathrm{~s}, 2 \mathrm{H}), 2.81(\mathrm{~d}, J=4.6 \mathrm{~Hz}, 3 \mathrm{H}) .{ }^{19} \mathrm{~F}$ NMR $(376 \mathrm{MHz}$, DMSO) $\delta 66.65$ (s). ${ }^{13} \mathrm{C}$ NMR (126 MHz, DMSO) $\delta 161.34,151.89,151.08,150.43,150.20$, 149.62, 138.67, 135.04, 134.28, 133.21, 132.74 (d, $J=25.2$ Hz), 132.45, 130.90, 126.94, 
$125.77,125.49,123.18,122.32,117.40,52.38,27.53$. HRMS calculated $m / z$ for C21H18CIFN5O5S2 $\left(\mathrm{M}+\mathrm{H}^{+}\right)$: 538.0416; found: 538.0416.

Compounds 1-10 and 13-15 were purchased from Enamine and used without further purification. LC-MS and NMR for these compounds were acquired at Enamine, with the exception of NMR spectra of compounds $\mathbf{4}$ and $\mathbf{9}$, which were acquired at UCSF.

Compound 1. 4-\{4-oxo-3H,4H-pyrido[3,4-d]pyrimidine-6-<smiles>O=C(Nc1ccc(S(=O)(=O)F)cc1)c1cc2c(=O)[nH]cnc2cn1</smilesamido\}benzene-1-sulfonyl fluoride (Enamine \#Z1743827349)

${ }^{1} \mathrm{H}$ NMR $\left(400 \mathrm{MHz}, \mathrm{DMSO}-d_{6}\right) \delta 12.89(\mathrm{~s}, 1 \mathrm{H}), 11.38$ (s, $1 \mathrm{H}), 9.15(\mathrm{~s}, 1 \mathrm{H}), 8.65(\mathrm{~s}, 1 \mathrm{H}), 8.39-8.34(\mathrm{~m}, 3 \mathrm{H}), 8.15-$ $8.11(\mathrm{~m}, 2 \mathrm{H}) .{ }^{13} \mathrm{C}$ NMR $\left(151 \mathrm{MHz}, \mathrm{DMSO}-d_{6}\right) \delta 163.14$, 160.04, 150.01, 149.80, 146.51,146.05, 145.89, 130.16, 129.22, 125.64 (d, J = 23.1 Hz), 121.28, 118.90. MS calculated for C14H10FN4O4S $\left(\mathrm{M}+\mathrm{H}^{+}\right)$: 349.0; found: 349.0.<smiles>O=c1[nH]ccc2ccc(NS(=O)(=O)c3cccc(S(=O)(=O)F)c3)cc12</smiles>

Compound 2. 3-[(1-oxo-1,2-dihydroisoquinolin-7yl)sulfamoyl]benzene-1-sulfonyl fluoride (Enamine \#Z2509440677)

${ }^{1} \mathrm{H}$ NMR $\left(400 \mathrm{MHz}\right.$, DMSO- $\left.d_{6}\right) \delta 11.28-11.22(\mathrm{~m}, 1 \mathrm{H})$, $10.80(\mathrm{~s}, 1 \mathrm{H}), 8.39(\mathrm{~d}, J=8.0 \mathrm{~Hz}, 1 \mathrm{H}), 8.32(\mathrm{~s}, 1 \mathrm{H}), 8.21(\mathrm{~d}$, $J=8.0 \mathrm{~Hz}, 1 \mathrm{H}), 7.96(\mathrm{t}, J=7.9,7.9 \mathrm{~Hz}, 1 \mathrm{H}), 7.85(\mathrm{~d}, J=2.3 \mathrm{~Hz}, 1 \mathrm{H}), 7.59(\mathrm{~d}, J=8.6 \mathrm{~Hz}, 1 \mathrm{H})$, $7.45(\mathrm{dd}, J=8.5,2.4 \mathrm{~Hz}, 1 \mathrm{H}), 7.09(\mathrm{t}, J=6.4,6.4 \mathrm{~Hz}, 1 \mathrm{H}), 6.47(\mathrm{~d}, J=7.1 \mathrm{~Hz}, 1 \mathrm{H}) .{ }^{13} \mathrm{C} \mathrm{NMR}$ $\left(151 \mathrm{MHz}, \mathrm{DMSO}-d_{6}\right) \delta 161.65,141.48,135.51,135.30,134.54,133.14,133.11$ (d, $J=24.9$ $\mathrm{Hz}), 132.75,128.97,128.23,127.12,126.55,126.54,118.48,104.58$. MS calculated for $\mathrm{C} 15 \mathrm{H} 12 \mathrm{FN} 2 \mathrm{O} 5 \mathrm{~S} 2\left(\mathrm{M}+\mathrm{H}^{+}\right)$: 383.0; found: 383.0.

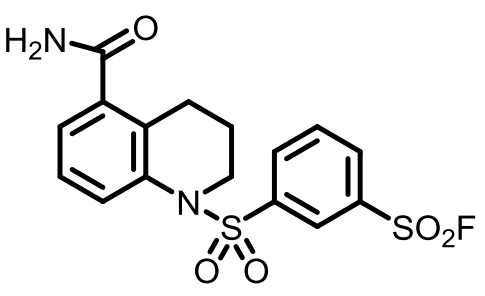

Compound 3. 3-[(5-carbamoyl-1,2,3,4-tetrahydroquinolin-1yl)sulfonyl]benzene-1-sulfonyl fluoride (Enamine \#Z1764342559)

${ }^{1} \mathrm{H}$ NMR $\left(400 \mathrm{MHz}\right.$, DMSO- $\left.d_{6}\right) \delta 8.50-8.43(\mathrm{~m}, 1 \mathrm{H}), 8.17-$ $8.11(\mathrm{~m}, 2 \mathrm{H}), 7.99(\mathrm{t}, J=8.2,8.2 \mathrm{~Hz}, 1 \mathrm{H}), 7.69(\mathrm{~s}, 1 \mathrm{H}), 7.62$ (d, $J=8.2 \mathrm{~Hz}, 1 \mathrm{H}), 7.41(\mathrm{~s}, 1 \mathrm{H}), 7.28(\mathrm{t}, J=7.9,7.9 \mathrm{~Hz}$, $1 \mathrm{H}), 7.25-7.18(\mathrm{~m}, 1 \mathrm{H}), 3.81(\mathrm{t}, J=6.1,6.1 \mathrm{~Hz}, 2 \mathrm{H}), 2.49$ $-2.45(\mathrm{~m}, 2 \mathrm{H}), 1.66$ (p, J=6.5, 6.5, 6.4, $6.4 \mathrm{~Hz}, 2 \mathrm{H}) .{ }^{13} \mathrm{C}$ NMR $(151 \mathrm{MHz}$, DMSO-d $) \delta 170.36$, 141.17, 138.12, 136.40, 134.55, 133.49, 133.29 (d, $J=25.2 \mathrm{~Hz}), 132.95,129.78,126.54$, 126.51, 125.55, 124.66, 46.69, 23.70, 22.03. MS calculated for $\mathrm{C} 16 \mathrm{H} 16 \mathrm{FN} 2 \mathrm{O} 5 \mathrm{~S} 2\left(\mathrm{M}+\mathrm{H}^{+}\right)$: 399.0; found: 399.0.

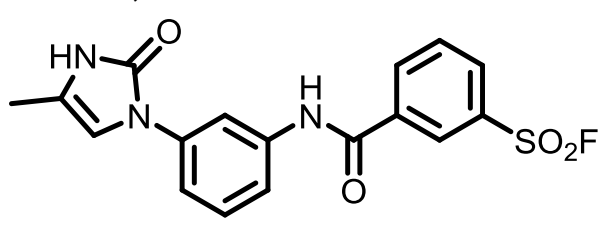

Compound 4. 3-\{[3-(4-methyl-2-oxo-2,3-dihydro-1Himidazol-1-yl)phenyl]carbamoyl\}benzene-1-sulfonyl fluoride (Enamine \#Z2768313507)

${ }^{1} \mathrm{H}$ NMR $\left(400 \mathrm{MHz}\right.$, DMSO- $\left.d_{6}\right) \delta 10.73$ (s, 1H), 10.31 (s, $1 \mathrm{H}), 8.66(\mathrm{~s}, 1 \mathrm{H}), 8.51(\mathrm{~d}, J=7.9 \mathrm{~Hz}, 1 \mathrm{H}), 8.37(\mathrm{~d}, J=8.0$ $\mathrm{Hz}, 1 \mathrm{H}), 8.18(\mathrm{~s}, 1 \mathrm{H}), 7.97$ (t, $J=7.9 \mathrm{~Hz}, 1 \mathrm{H}), 7.65$ (d, $J=$ $7.5 \mathrm{~Hz}, 1 \mathrm{H}), 7.51-7.31(\mathrm{~m}, 2 \mathrm{H}), 6.61(\mathrm{~s}, 1 \mathrm{H}), 3.17(\mathrm{~s}, 2 \mathrm{H}), 1.99(\mathrm{~d}, J=1.1 \mathrm{~Hz}, 3 \mathrm{H}) .{ }^{19} \mathrm{~F} \mathrm{NMR}$ (376 MHz, DMSO) $\delta 66.44$ (s). ${ }^{13} \mathrm{C}$ NMR (100 MHz, DMSO) $\delta 163.60,152.54,139.61,138.32$, 
137.00, 136.27, 132.32 (d, $J=23.8 \mathrm{~Hz}$ ), 131.63, 131.38, 129.68, 127.80, 119.20, 117.16, 116.32, 113.02, 106.02, 49.07, 11.06. MS calculated for $\mathrm{C} 17 \mathrm{H} 15 \mathrm{FN} 3 \mathrm{O} 4 \mathrm{~S}\left(\mathrm{M}_{+} \mathrm{H}^{+}\right)$: 376.1 ; found: 376.0 .<smiles>NC(=O)c1ccc(CNC(=O)c2cccc(S(F)(F)F)c2)cn1</smiles>

Compound 5. 3-\{[(6-carbamoylpyridin-3yl)methyl]carbamoyl\}benzene-1-sulfonyl fluoride (Enamine \#Z2759818038)

${ }^{1} \mathrm{H}$ NMR $\left(400 \mathrm{MHz}\right.$, DMSO- $\left.d_{6}\right) \delta 9.56(\mathrm{t}, J=5.7,5.7 \mathrm{~Hz}$, $1 \mathrm{H}), 8.65-8.60(\mathrm{~m}, 1 \mathrm{H}), 8.59(\mathrm{~s}, 1 \mathrm{H}), 8.43(\mathrm{~d}, J=7.9 \mathrm{~Hz}$, $1 \mathrm{H}), 8.33(\mathrm{~d}, J=8.0 \mathrm{~Hz}, 1 \mathrm{H}), 8.09(\mathrm{~s}, 1 \mathrm{H}), 8.01(\mathrm{~d}, J=8.0$

$\mathrm{Hz}, 1 \mathrm{H}), 7.97-7.89(\mathrm{~m}, 2 \mathrm{H}), 7.61(\mathrm{~s}, 1 \mathrm{H}), 4.62(\mathrm{~d}, J=5.7 \mathrm{~Hz}, 2 \mathrm{H}) .{ }^{13} \mathrm{C}$ NMR $(151 \mathrm{MHz}$, DMSO$\left.d_{6}\right) \delta 166.33,164.50,149.66,148.22,137.88,137.01,136.17,135.79,132.39$ (d, J = $\left.23.8 \mathrm{~Hz}\right)$, 131.47, 131.40, 127.33, 122.18, 41.04. MS calculated for $\mathrm{C} 14 \mathrm{H} 13 \mathrm{FN} 3 \mathrm{O} 4 \mathrm{~S}\left(\mathrm{M}+\mathrm{H}^{+}\right): 338.1$; found: 338.1 .

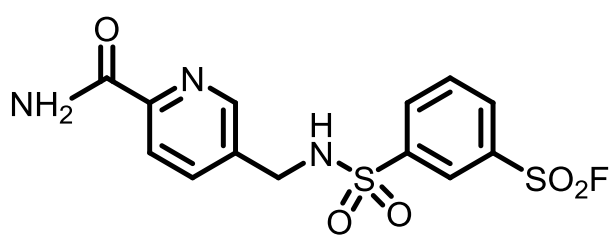

Compound 6. 3-\{[(6-carbamoylpyridin-3yl)methyl]sulfamoyl\}benzene-1-sulfonyl fluoride (Enamine \#Z2759818059)

${ }^{1} \mathrm{H}$ NMR $\left(400 \mathrm{MHz}\right.$, DMSO- $\left.d_{6}\right) \delta 8.76(\mathrm{t}, J=6.1,6.1 \mathrm{~Hz}$,

$1 \mathrm{H}), 8.44(\mathrm{~s}, 1 \mathrm{H}), 8.36(\mathrm{~d}, J=7.9 \mathrm{~Hz}, 1 \mathrm{H}), 8.33-8.25(\mathrm{~m}$, 2H), $8.02(\mathrm{~s}, 1 \mathrm{H}), 7.96(\mathrm{t}, J=7.9,7.9 \mathrm{~Hz}, 1 \mathrm{H}), 7.88(\mathrm{~d}, J=$ $7.9 \mathrm{~Hz}, 1 \mathrm{H}), 7.81-7.74(\mathrm{~m}, 1 \mathrm{H}), 7.59(\mathrm{~s}, 1 \mathrm{H}), 4.25(\mathrm{~d}, J=6.1 \mathrm{~Hz}, 2 \mathrm{H}) .{ }^{13} \mathrm{C}$ NMR $(151 \mathrm{MHz}$, DMSO- $\left.d_{6}\right) \delta 166.10,149.84,148.21,143.21,137.14,135.93,134.55,133.00$ (d, J = $24.7 \mathrm{~Hz}$ ), 132.54, 132.48, 126.49, 121.89, 43.87. MS calculated for C13H13FN3O5S2 $\left(\mathrm{M}_{+} \mathrm{H}^{+}\right)$: 374.0; found: 374.0 .<smiles>NC(=O)c1ccc(OS(=O)(=O)c2cccc(S(=O)(=O)F)c2)cc1</smiles>

Compound 7.

4-carbamoylphenyl 3-(fluorosulfonyl)benzene-1-sulfonate (Enamine \#Z2768264767)

${ }^{1} \mathrm{H}$ NMR $\left(400 \mathrm{MHz}\right.$, DMSO- $\left.d_{6}\right) \delta 8.61(\mathrm{~d}, J=8.0 \mathrm{~Hz}, 1 \mathrm{H})$, $8.45-8.36(\mathrm{~m}, 2 \mathrm{H}), 8.09(\mathrm{t}, J=7.9,7.9 \mathrm{~Hz}, 1 \mathrm{H}), 8.03(\mathrm{~s}$, $1 \mathrm{H}), 7.89(\mathrm{~d}, J=8.8 \mathrm{~Hz}, 2 \mathrm{H}), 7.47(\mathrm{~s}, 1 \mathrm{H}), 7.22(\mathrm{~d}, J=8.7$ $\mathrm{Hz}, 2 \mathrm{H}) .{ }^{13} \mathrm{C}$ NMR $\left(126 \mathrm{MHz}\right.$, DMSO- $\left.d_{6}\right) \delta 167.01,151.00$, 136.42, 136.24, 135.18, 134.29, 133.72 (d, $J=25.8 \mathrm{~Hz}), 133.21,130.11,128.18,122.51 . \mathrm{MS}$ calculated for $\mathrm{C} 13 \mathrm{H} 11 \mathrm{FNO6S2}\left(\mathrm{M}+\mathrm{H}^{+}\right)$: 360.0; found: 360.0 .<smiles>N#Cc1ccc(CN(c2ccc3cc[nH]c(=O)c3c2)S(=O)(=O)c2cccc(S(=O)(=O)F)c2)cc1</smiles>

Compound 8. 3-\{[(4-cyanophenyl)methyl](1-oxo-1,2dihydroisoquinolin-7-yl)sulfamoyl\} benzene-1-sulfonyl fluoride (Enamine \#Z3210398376)

${ }^{1} \mathrm{H}$ NMR $\left(400 \mathrm{MHz}\right.$, DMSO- $\left.d_{6}\right) \delta 11.35(\mathrm{~d}, J=5.6 \mathrm{~Hz}, 1 \mathrm{H})$, $8.53(\mathrm{~d}, J=8.0 \mathrm{~Hz}, 1 \mathrm{H}), 8.20(\mathrm{~d}, J=8.0 \mathrm{~Hz}, 1 \mathrm{H}), 8.07(\mathrm{~d}, J=$ $8.0 \mathrm{~Hz}, 1 \mathrm{H}), 8.05(\mathrm{~s}, 1 \mathrm{H}), 7.84(\mathrm{~d}, J=2.4 \mathrm{~Hz}, 1 \mathrm{H}), 7.75(\mathrm{~d}, J$ $=8.0 \mathrm{~Hz}, 2 \mathrm{H}), 7.59(\mathrm{~d}, J=8.5 \mathrm{~Hz}, 1 \mathrm{H}), 7.50(\mathrm{~d}, J=8.0 \mathrm{~Hz}$, 2H), 7.45 (dd, $J=8.5,2.4 \mathrm{~Hz}, 1 \mathrm{H}), 7.19(\mathrm{t}, J=6.4,6.4 \mathrm{~Hz}, 1 \mathrm{H}), 6.50(\mathrm{~d}, J=7.1 \mathrm{~Hz}, 1 \mathrm{H}), 5.04(\mathrm{~s}$, $2 \mathrm{H}) .{ }^{13} \mathrm{C}$ NMR $\left(126 \mathrm{MHz}\right.$, DMSO- $\left.d_{6}\right) \delta 161.57,142.07,139.46,138.10,136.16,135.40,133.59$, 133.28 (d, $J=25.3 \mathrm{~Hz}$ ), 132.95, 132.71, 130.63, 129.48, 127.99, 127.31, 126.96, 126.85, 
118.99, 110.99, 104.46, 53.81. MS calculated for C23H17FN3O5S2 $\left(\mathrm{M}+\mathrm{H}^{+}\right)$: 498.1; found: 498.2.<smiles>O=c1[nH]ccc2ccc(N(Cc3ccncc3)S(=O)(=O)c3cccc(S(=O)(=O)F)c3)cc12</smiles>

Compound 9. 3-[(1-oxo-1,2-dihydroisoquinolin-7-yl)[(pyridin4-yl)methyl]sulfamoyl]benzene-1-sulfonyl fluoride (Enamine \#Z3005675912)

${ }^{1} \mathrm{H}$ NMR (400 MHz, DMSO) $\delta 11.36(\mathrm{~d}, J=5.6 \mathrm{~Hz}, 1 \mathrm{H}), 8.54$ $(\mathrm{d}, J=8.0 \mathrm{~Hz}, 1 \mathrm{H}), 8.47(\mathrm{dd}, J=4.5,1.5 \mathrm{~Hz}, 2 \mathrm{H}), 8.20(\mathrm{~d}, J=$ $8.1 \mathrm{~Hz}, 1 \mathrm{H}), 8.10-7.98(\mathrm{~m}, 2 \mathrm{H}), 7.84(\mathrm{~d}, J=2.3 \mathrm{~Hz}, 1 \mathrm{H})$, $7.60(\mathrm{~d}, J=8.5 \mathrm{~Hz}, 1 \mathrm{H}), 7.49(\mathrm{dd}, J=8.5,2.4 \mathrm{~Hz}, 1 \mathrm{H}), 7.32$ $(\mathrm{d}, J=6.0 \mathrm{~Hz}, 2 \mathrm{H}), 7.25-7.14(\mathrm{~m}, 1 \mathrm{H}), 6.51(\mathrm{~d}, J=7.0 \mathrm{~Hz}, 1 \mathrm{H}), 4.99(\mathrm{~s}, 2 \mathrm{H}) .{ }^{13} \mathrm{C}$ NMR $(100$ MHz, DMSO) $\delta 163.45,161.09,149.79,144.94,138.85,137.61,135.73,134.95,133.16$, 132.77 (d, $J=24.8 \mathrm{~Hz}$ ), 132.47, 132.26, 130.16, 127.52, 126.86, 126.36, 126.34, 122.92, 103.98, 52.69. MS calculated for C21H17FN3O5S2 $\left(\mathrm{M}+\mathrm{H}^{+}\right): 474.1$; found: 474.0.<smiles>O=c1[nH]ccc2ccc(N(Cc3ccnc(Cl)c3)S(=O)(=O)c3cccc(S(=O)(=O)F)c3)cc12</smiles>

Compound 10. 3-\{[(2-chloropyridin-4-yl)methyl](1-oxo-1,2dihydroisoquinolin-7-yl)sulfamoyl\}benzene -1-sulfonyl fluoride (Enamine \#Z3386495120)

${ }^{1} \mathrm{H}$ NMR $\left(400 \mathrm{MHz}, \mathrm{DMSO}-d_{6}\right) \delta 11.36(\mathrm{~d}, J=5.6 \mathrm{~Hz}, 1 \mathrm{H})$, $8.54(\mathrm{~d}, J=8.0 \mathrm{~Hz}, 1 \mathrm{H}), 8.33(\mathrm{~d}, J=5.1 \mathrm{~Hz}, 1 \mathrm{H}), 8.18(\mathrm{~d}, J=$ $8.0 \mathrm{~Hz}, 1 \mathrm{H}), 8.11-8.02(\mathrm{~m}, 2 \mathrm{H}), 7.87-7.82(\mathrm{~m}, 1 \mathrm{H}), 7.63$ $(\mathrm{d}, J=8.5 \mathrm{~Hz}, 1 \mathrm{H}), 7.50(\mathrm{dd}, J=8.6,2.4 \mathrm{~Hz}, 1 \mathrm{H}), 7.42(\mathrm{~s}$, $1 \mathrm{H}), 7.40(\mathrm{~d}, J=5.1 \mathrm{~Hz}, 1 \mathrm{H}), 7.20(\mathrm{t}, J=6.4,6.4 \mathrm{~Hz}, 1 \mathrm{H})$, $6.52(\mathrm{~d}, J=7.1 \mathrm{~Hz}, 1 \mathrm{H}), 5.03(\mathrm{~s}, 2 \mathrm{H}) .{ }^{13} \mathrm{C}$ NMR $\left(151 \mathrm{MHz}, \mathrm{DMSO}-d_{6}\right) \delta 161.52,150.88,150.61$, 149.87, 139.11, 138.16, 136.18, 135.41, 133.67, 133.27 (d, $J=25.0 \mathrm{~Hz}$ ), $132.91,132.70$, 130.68, 128.08, 127.35, 126.86, 126.68, 123.58, 122.70, 104.43, 52.72. MS calculated for C21H16CIFN3O5S2 $\left(\mathrm{M}+\mathrm{H}^{+}\right)$: 508.0; found: 508.0.<smiles>O=c1[nH]ccc2ccc(N(Cc3cccc(O)c3)S(=O)(=O)c3cccc(S(=O)(=O)F)c3)cc12</smiles>

Compound 13. 3-\{[(3-hydroxyphenyl)methyl](1-oxo-1,2dihydroisoquinolin-7-yl)sulfamoyl\}benzene-1- sulfonyl fluoride (Enamine \#Z3011917094) ${ }^{1} \mathrm{H}$ NMR $\left(400 \mathrm{MHz}, \mathrm{DMSO}-d_{6}\right) \delta 10.91(\mathrm{~d}, J=5.0 \mathrm{~Hz}, 1 \mathrm{H})$, $8.49(\mathrm{~d}, J=8.2 \mathrm{~Hz}, 1 \mathrm{H}), 8.39-8.33(\mathrm{~m}, 1 \mathrm{H}), 8.31(\mathrm{~d}, J=7.9$ $\mathrm{Hz}, 1 \mathrm{H}), 7.96(\mathrm{t}, J=7.9,7.9 \mathrm{~Hz}, 1 \mathrm{H}), 7.40-7.31(\mathrm{~m}, 3 \mathrm{H})$, $7.14-7.04(\mathrm{~m}, 2 \mathrm{H}), 7.04-6.98(\mathrm{~m}, 1 \mathrm{H}), 6.98-6.93(\mathrm{~m}$, $1 \mathrm{H}), 6.84(\mathrm{t}, J=6.2,6.2 \mathrm{~Hz}, 1 \mathrm{H}), 6.37(\mathrm{~d}, J=7.0 \mathrm{~Hz}, 1 \mathrm{H})$, $4.33(\mathrm{~s}, 2 \mathrm{H}) .{ }^{13} \mathrm{C}$ NMR $\left(151 \mathrm{MHz}, \mathrm{DMSO}-d_{6}\right) \delta 162.01,149.40,147.43,143.44,136.53,136.09$, 134.87, 132.91, 130.66, 128.70, 127.99, 127.87, 127.59, 126.92, 124.41, 120.81, 120.71, 120.55, 105.79, 105.34, 46.09. MS calculated for C22H18FN2O6S2 $\left(\mathrm{M}+\mathrm{H}^{+}\right)$: 489.1; found: 489.0 . 
<smiles>O=c1[nH]ccc2ccc(N(Cc3cc4cnccc4o3)S(=O)(=O)c3cccc(S(=O)(=O)F)c3)cc12</smiles>

Compound 14. 3-[(\{furo[3,2-c]pyridin-2-yl\}methyl)(1-oxo1,2-dihydroisoquinolin-7-yl)sulfamoyl]benzene -1-sulfonyl fluoride (Enamine \#Z3210398380)

${ }^{1} \mathrm{H}$ NMR $\left(400 \mathrm{MHz}\right.$, DMSO- $\left.d_{6}\right) \delta 11.35(\mathrm{~d}, J=5.6 \mathrm{~Hz}, 1 \mathrm{H})$, $8.80(\mathrm{~s}, 1 \mathrm{H}), 8.51(\mathrm{~d}, J=8.2 \mathrm{~Hz}, 1 \mathrm{H}), 8.41(\mathrm{~d}, J=5.8 \mathrm{~Hz}$, $1 \mathrm{H}), 8.20(\mathrm{~d}, J=7.9 \mathrm{~Hz}, 1 \mathrm{H}), 8.11(\mathrm{~s}, 1 \mathrm{H}), 8.04(\mathrm{t}, J=8.0$, $8.0 \mathrm{~Hz}, 1 \mathrm{H}), 7.87(\mathrm{~d}, J=2.4 \mathrm{~Hz}, 1 \mathrm{H}), 7.64-7.55(\mathrm{~m}, 2 \mathrm{H})$, $7.43(\mathrm{dd}, J=8.5,2.4 \mathrm{~Hz}, 1 \mathrm{H}), 7.19(\mathrm{t}, J=6.4,6.4 \mathrm{~Hz}, 1 \mathrm{H})$, $6.85(\mathrm{~s}, 1 \mathrm{H}), 6.51(\mathrm{~d}, J=7.1 \mathrm{~Hz}, 1 \mathrm{H}), 5.22(\mathrm{~s}, 2 \mathrm{H}) \cdot{ }^{13} \mathrm{C}$ NMR $\left(126 \mathrm{MHz}\right.$, DMSO-d $\left.\mathrm{d}_{6}\right) \delta 161.56$, 159.26, 153.48, 145.08, 144.50, 139.91, 138.30, 136.03, 135.42, 133.53, 133.21 (d, $J=25.2$ Hz), 132.88, 132.83, 130.70, 128.04, 127.32, 127.18, 126.90, 125.24, 107.41, 105.54, 104.46, 48.18. MS calculated for C23H17FN3O6S2 $\left(\mathrm{M}+\mathrm{H}^{+}\right)$: 514.1; found: 514.0.

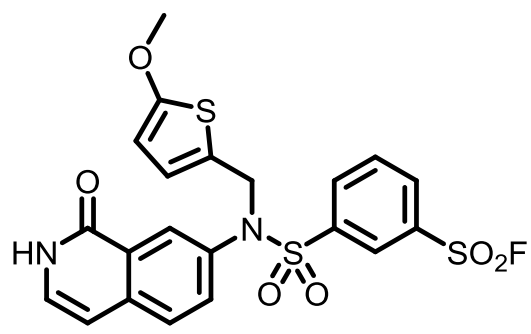

Compound 15. 3-\{[(5-methoxythiophen-2-yl)methyl](1-oxo1,2-dihydroisoquinolin-7-yl)sulfamoyl\} benzene-1-sulfonyl fluoride (Enamine \#Z3210398377)

${ }^{1} \mathrm{H}$ NMR $\left(400 \mathrm{MHz}\right.$, DMSO- $\left.d_{6}\right) \delta 11.37(\mathrm{~d}, J=5.6 \mathrm{~Hz}, 1 \mathrm{H})$, $8.51(\mathrm{~d}, J=8.5 \mathrm{~Hz}, 1 \mathrm{H}), 8.17(\mathrm{~d}, J=8.4 \mathrm{~Hz}, 1 \mathrm{H}), 8.08-8.00$ $(\mathrm{m}, 2 \mathrm{H}), 7.81(\mathrm{~d}, J=2.4 \mathrm{~Hz}, 1 \mathrm{H}), 7.61(\mathrm{~d}, J=8.5 \mathrm{~Hz}, 1 \mathrm{H})$, $7.38(\mathrm{dd}, J=8.5,2.4 \mathrm{~Hz}, 1 \mathrm{H}), 7.21(\mathrm{t}, J=6.4,6.4 \mathrm{~Hz}, 1 \mathrm{H})$, $6.53(\mathrm{~d}, J=7.1 \mathrm{~Hz}, 1 \mathrm{H}), 6.44(\mathrm{~d}, J=3.8 \mathrm{~Hz}, 1 \mathrm{H}), 5.95(\mathrm{~d}, J=$ $3.9 \mathrm{~Hz}, 1 \mathrm{H}), 4.97$ (s, 2H), $3.74(\mathrm{~s}, 3 \mathrm{H}) .{ }^{13} \mathrm{C}$ NMR (126 MHz, DMSO-d $) \delta 166.58,161.65,140.01$, 138.14, 135.83, 135.30, 133.41, 133.23 (d, J = 25.2 Hz), 133.01, 132.86, 130.56, 127.82, $127.48,127.20,126.81,126.57,124.02,104.53,103.18,60.38,50.57$. MS calculated for C21H18FN2O6S3 $\left(\mathrm{M}+\mathrm{H}^{+}\right)$: 509.0; found: 509.0. 


\section{Supplemental references}

(1) Lovell, S. C.; Word, J. M.; Richardson, J. S.; Richardson, D. C. The penultimate rotamer library. Proteins: Struct., Funct., Bioinf. 2000, 40 (3), 389-408.

(2) Pettersen, E. F.; Goddard, T. D.; Huang, C. C.; Couch, G. S.; Greenblatt, D. M.; Meng, E. C.; Ferrin, T. E. UCSF Chimera-A visualization system for exploratory research and analysis. J. Comput. Chem. 2004, 25 (13), 1605-1612.

(3) Coleman, R. G.; Carchia, M.; Sterling, T.; Irwin, J. J.; Shoichet, B. K. Ligand pose and orientational sampling in molecular docking. PLoS One 2013, 8 (10), e75992.

(4) Shraga, A.; Olshvang, E.; Davidzohn, N.; Khoshkenar, P.; Germain, N.; Shurrush, K.; Carvalho, S.; Avram, L.; Albeck, S.; Unger, T.; Lefker, B.; Subramanyam, C.; Hudkins, R. L.; Mitchell, A.; Shulman, Z.; Kinoshita, T.; London, N. Covalent Docking Identifies a Potent and Selective MKK7 Inhibitor. Cell Chem. Biol. 2019, 26 (1), 98-108.e105.

(5) Zhao, Q.; Ouyang, X.; Wan, X.; Gajiwala, K. S.; Kath, J. C.; Jones, L. H.; Burlingame, A. L.; Taunton, J. Broad-spectrum kinase profiling in live cells with lysine-targeted sulfonyl fluoride probes. J. Am. Chem. Soc. 2017, 139 (2), 680-685.

(6) Del Rio, A.; Sgobba, M.; Parenti, M. D.; Degliesposti, G.; Forestiero, R.; Percivalle, C.; Conte, P. F.; Freccero, M.; Rastelli, G. A computational workflow for the design of irreversible inhibitors of protein kinases. J. Comput.-Aided Mol. Des. 2010, 24 (3), 183-194.

(7) Case, D. A.; Cheatham, T. E.; Darden, T.; Gohlke, H.; Luo, R.; Merz, K. M.; Onufriev, A.; Simmerling, C.; Wang, B.; Woods, R. J. The Amber biomolecular simulation programs. J. Comput. Chem. 2005, 26 (16), 1668-1688.

(8) Wang, J.; Wolf, R. M.; Caldwell, J. W.; Kollman, P. A.; Case, D. A. Development and testing of a general amber force field. J. Comput. Chem. 2004, 25 (9), 1157-1174.

(9) London, N.; Miller, R. M.; Krishnan, S.; Uchida, K.; Irwin, J. J.; Eidam, O.; Gibold, L.; Cimermančič, P.; Bonnet, R.; Shoichet, B. K.; Taunton, J. Covalent docking of large libraries for the discovery of chemical probes. Nat. Chem. Biol. 2014, 10, 1066-1072.

(10) Kearsley, S. K.; Underwood, D. J.; Sheridan, R. P.; Miller, M. D. Flexibases: A way to enhance the use of molecular docking methods. J. Comput.-Aided Mol. Des. 1994, 8 (5), 565582.

(11) Rydzik, A. M.; Warminski, M.; Sikorski, P. J.; Baranowski, M. R.; Walczak, S.; Kowalska, J.; Zuberek, J.; Lukaszewicz, M.; Nowak, E.; W. Claridge, T. D.; Darzynkiewicz, E.; Nowotny, M.; Jemielity, J. mRNA cap analogues substituted in the tetraphosphate chain with CX2: identification of O-to-CCl2 as the first bridging modification that confers resistance to decapping without impairing translation. Nucleic Acids Res. 2017, 45 (15), 8661-8675.

(12) Kabsch, W. Automatic processing of rotation diffraction data from crystals of initially unknown symmetry and cell constants. J. Appl. Crystallogr 1993, 26 (6), 795-800.

(13) Adams, P. D.; Afonine, P. V.; Bunkoczi, G.; Chen, V. B.; Davis, I. W.; Echols, N.; Headd, J. J.; Hung, L.-W.; Kapral, G. J.; Grosse-Kunstleve, R. W.; McCoy, A. J.; Moriarty, N. W.; Oeffner, R.; Read, R. J.; Richardson, D. C.; Richardson, J. S.; Terwilliger, T. C.; Zwart, P. H. PHENIX: a comprehensive Python-based system for macromolecular structure solution. Acta Crystallogr., Sect. D: Struct. Biol. 2010, 66 (2), 213-221.

(14) Emsley, P.; Cowtan, K. Coot: model-building tools for molecular graphics. Acta Crystallogr., Sect. D: Struct. Biol. 2004, 60 (12 Part 1), 2126-2132. 
(15) Murshudov, G. N.; Vagin, A. A.; Dodson, E. J. Refinement of Macromolecular Structures by the Maximum-Likelihood Method. Acta Crystallogr., Sect. D: Struct. Biol. 1997, 53 (3), 240-255.

(16) The CCP4 suite: programs for protein crystallography. Acta Crystallogr., Sect. D:

Struct. Biol. 1994, 50 (5), 760-763.

(17) Gibson, D. G.; Young, L.; Chuang, R.-Y.; Venter, J. C.; Hutchison lii, C. A.; Smith, H. O. Enzymatic assembly of DNA molecules up to several hundred kilobases. Nat. Methods 2009, 6, 343-345.

(18) Carelli, J. D.; Sethofer, S. G.; Smith, G. A.; Miller, H. R.; Simard, J. L.; Merrick, W. C.; Jain, R. K.; Ross, N. T.; Taunton, J. Ternatin and improved synthetic variants kill cancer cells by targeting the elongation factor-1A ternary complex. eLife 2015, 4, e10222.

(19) Poulin, F.; Gingras, A.-C.; Olsen, H.; Chevalier, S.; Sonenberg, N. 4E-BP3, a New Member of the Eukaryotic Initiation Factor 4E-binding Protein Family. J. Biol. Chem. 1998, 273 (22), $14002-14007$.

(20) Brusniak, M.-Y. K.; Chu, C. S.; Kusebauch, U.; Sartain, M. J.; Watts, J. D.; Moritz, R. L. An assessment of current bioinformatic solutions for analyzing LC-MS data acquired by selected reaction monitoring technology. Proteomics 2012, 12 (8), 1176-1184. 
NMR Spectra

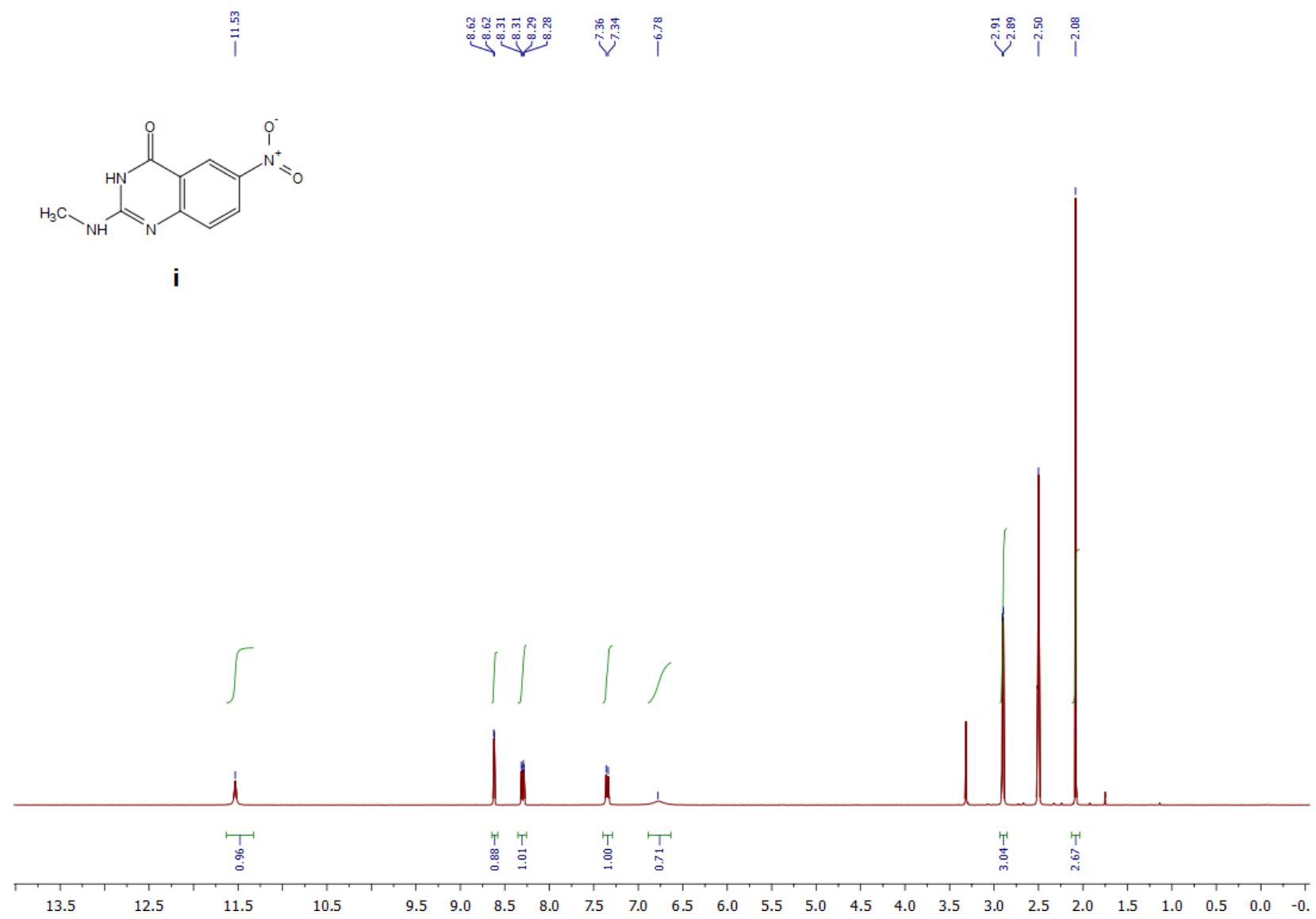




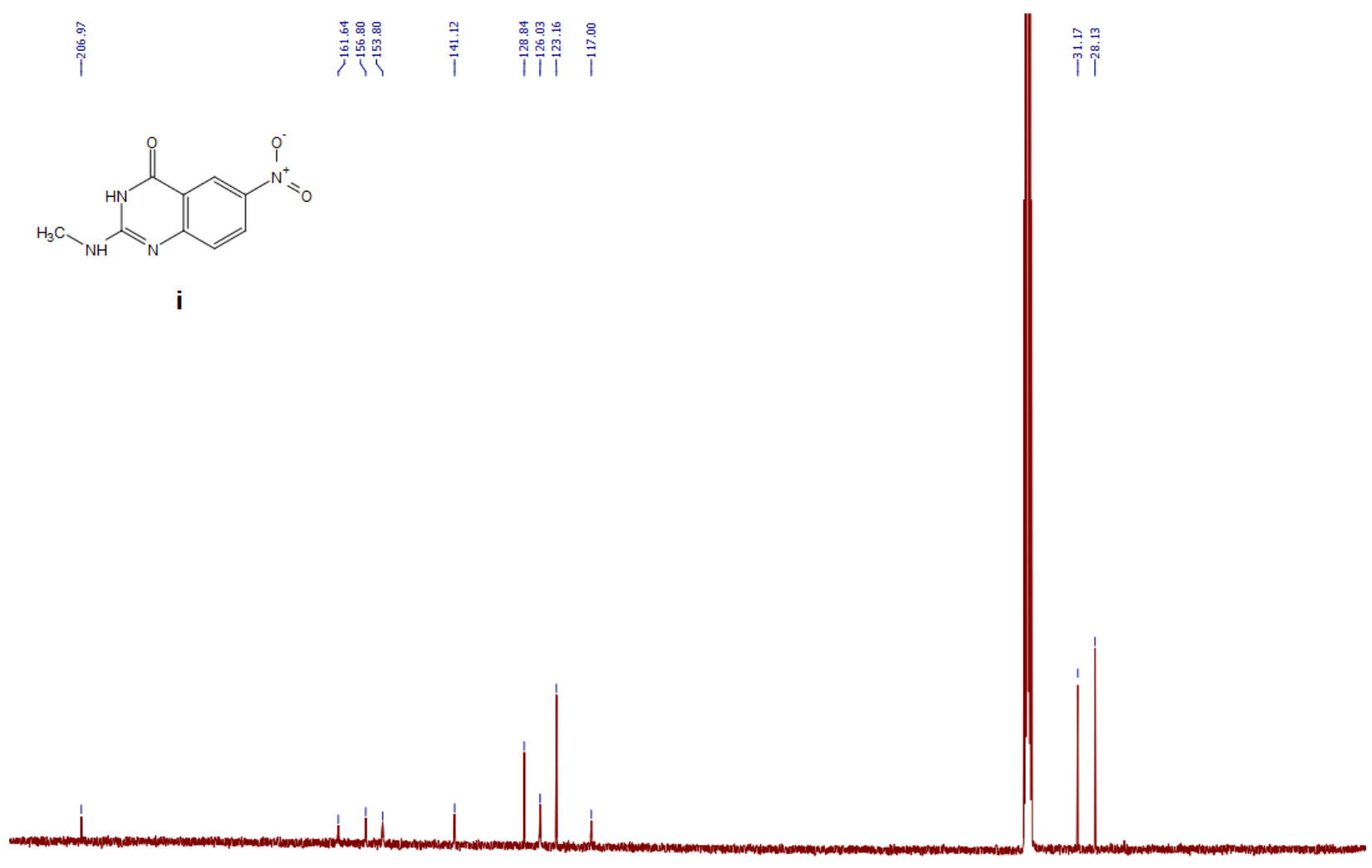

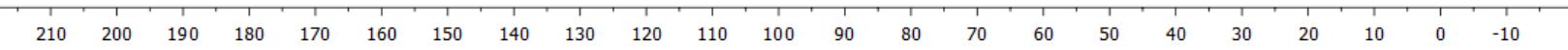




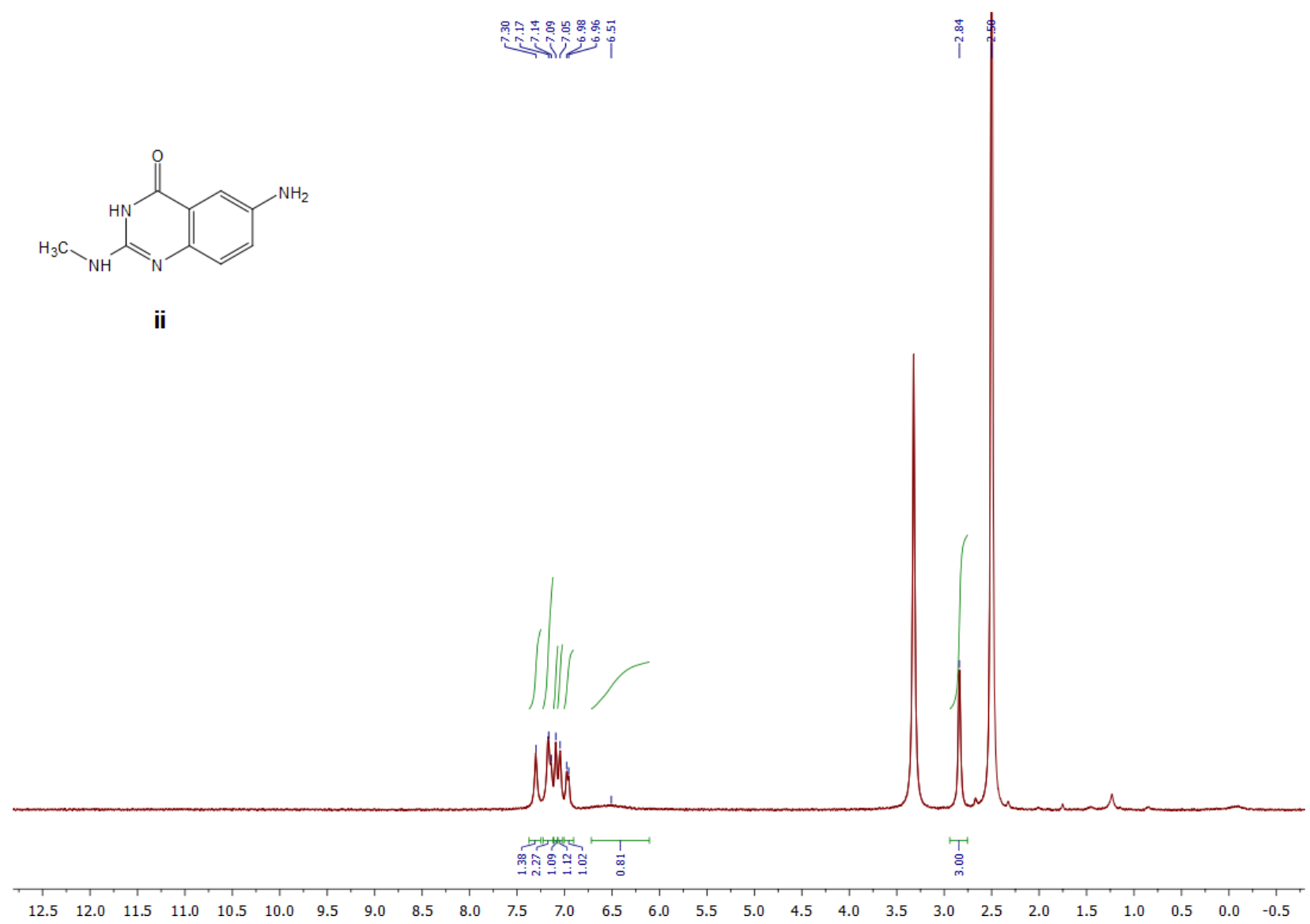




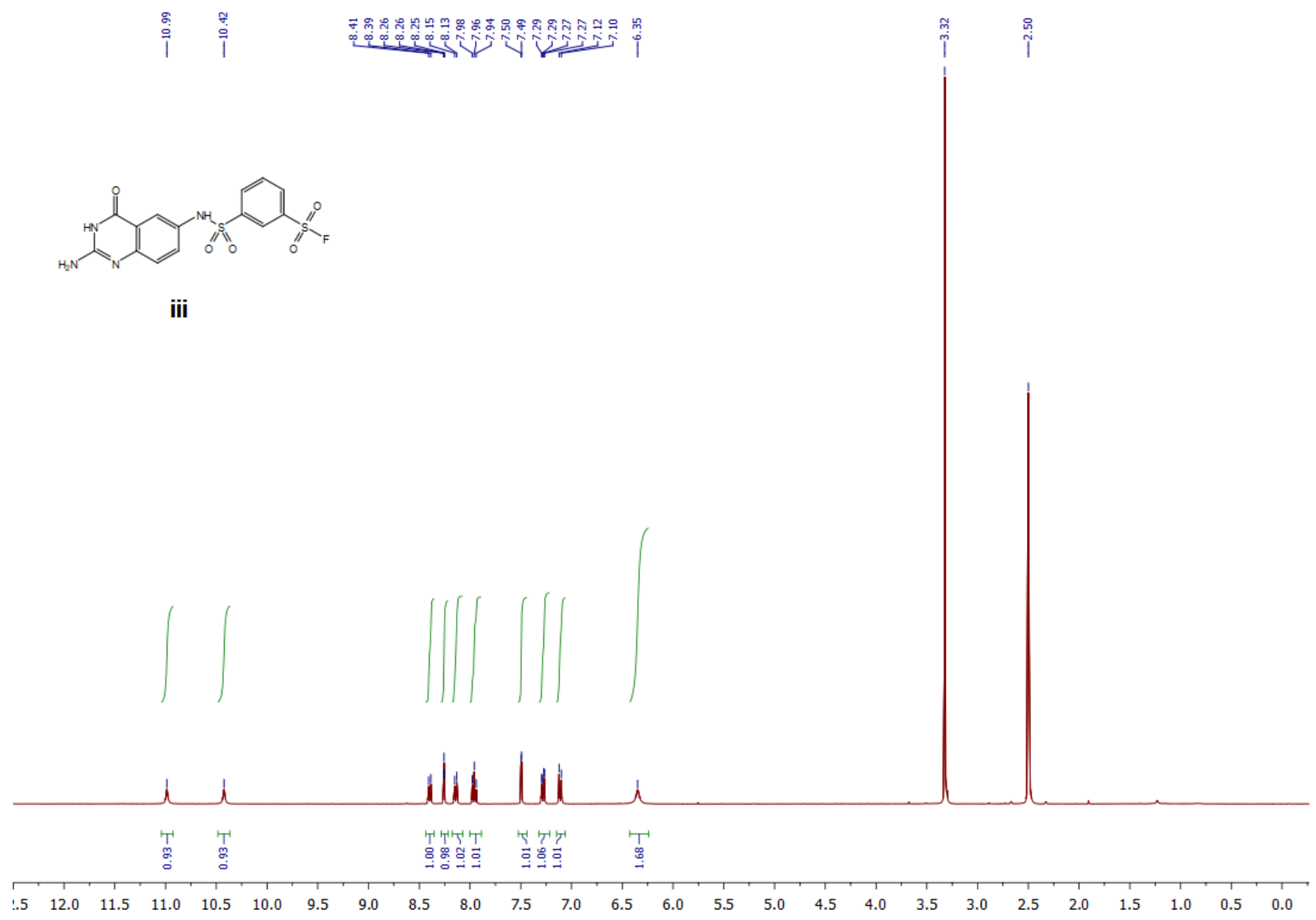




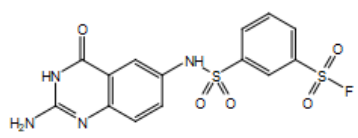

iii

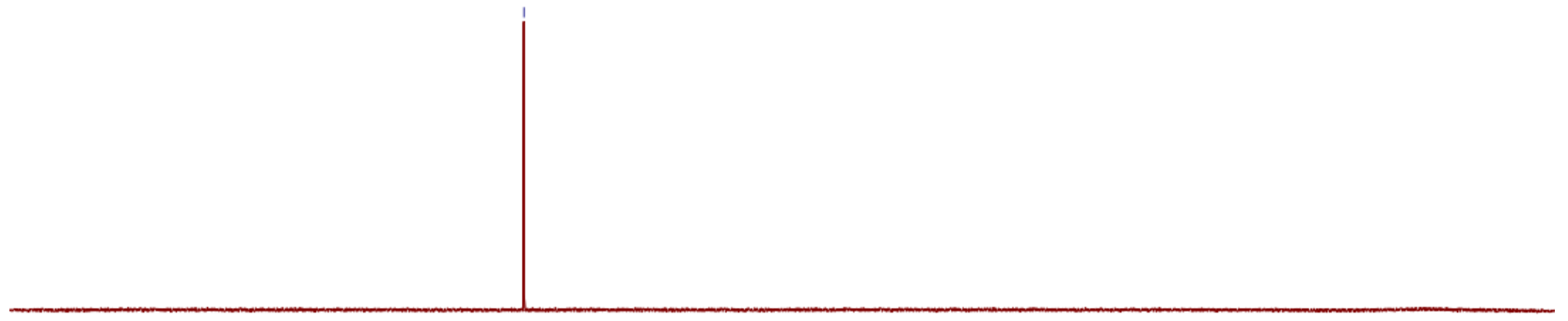

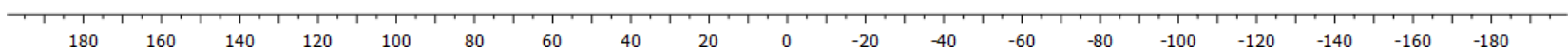




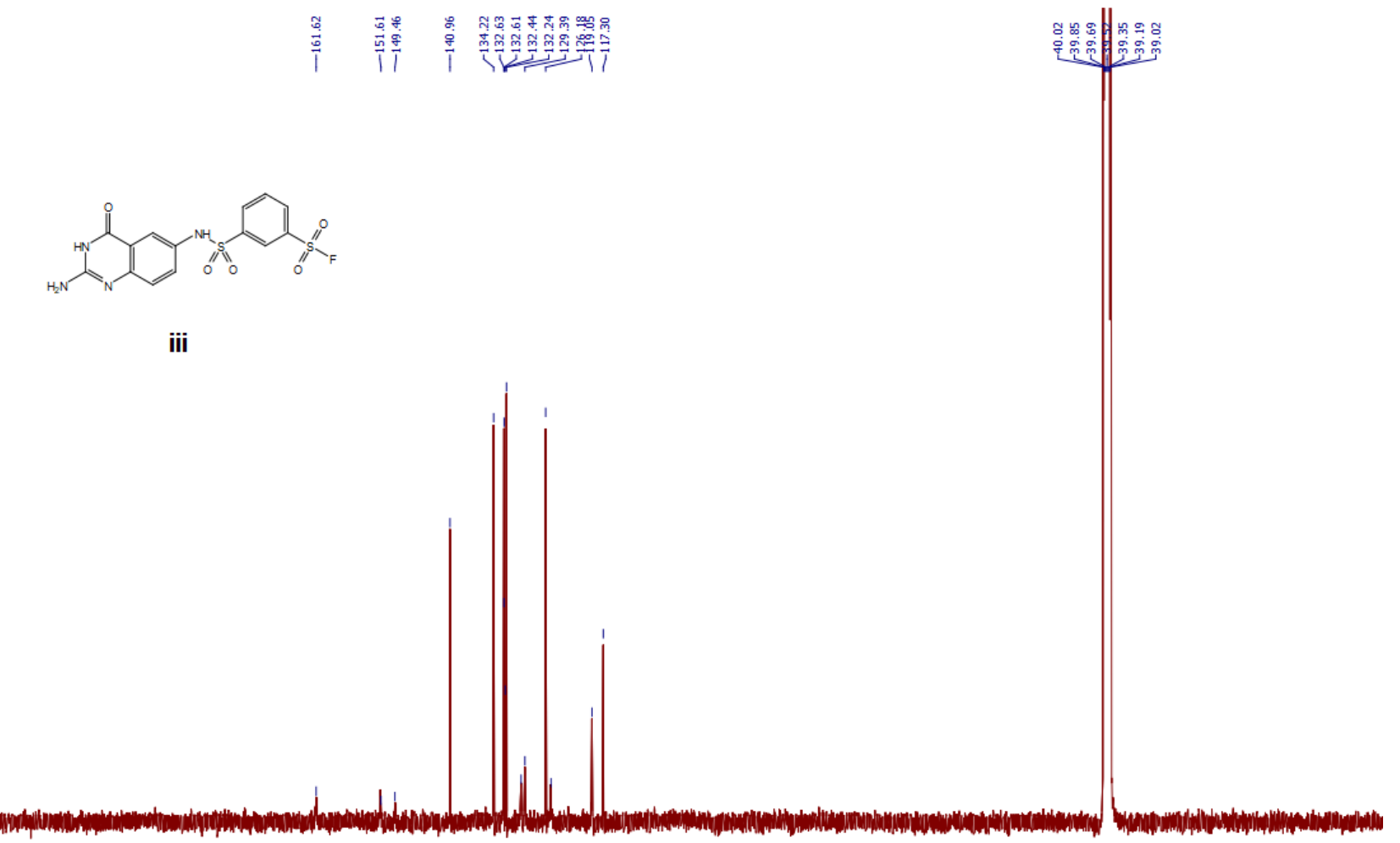

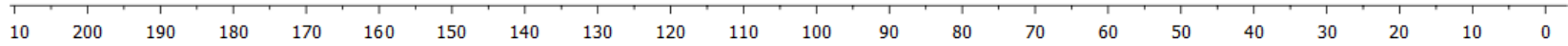




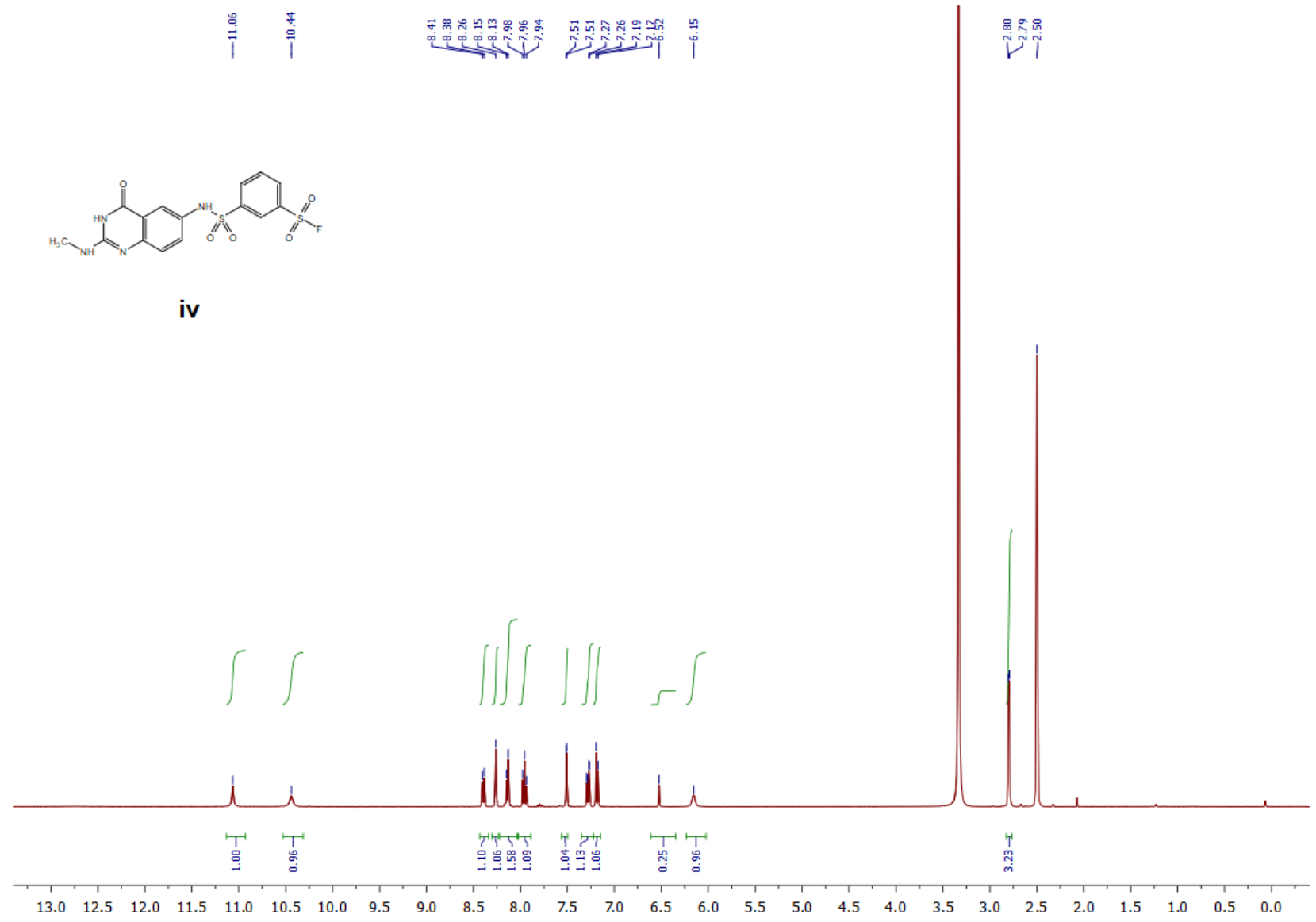




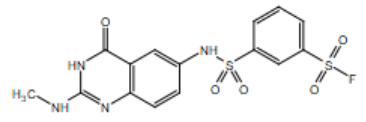

iv

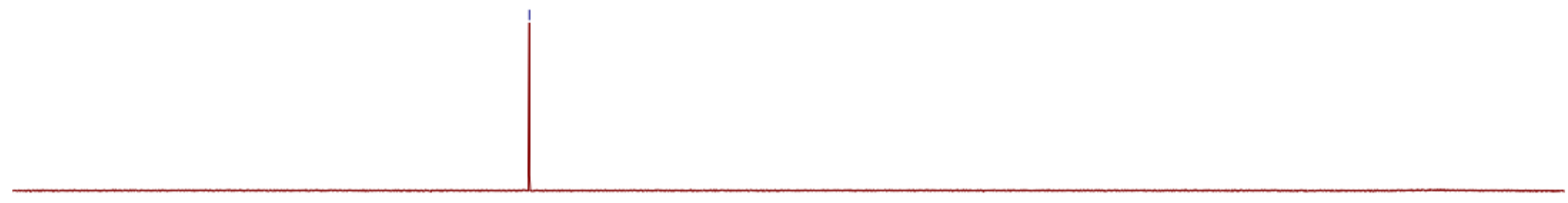

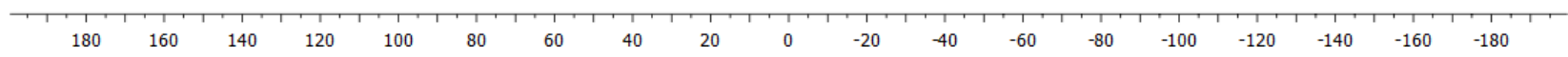




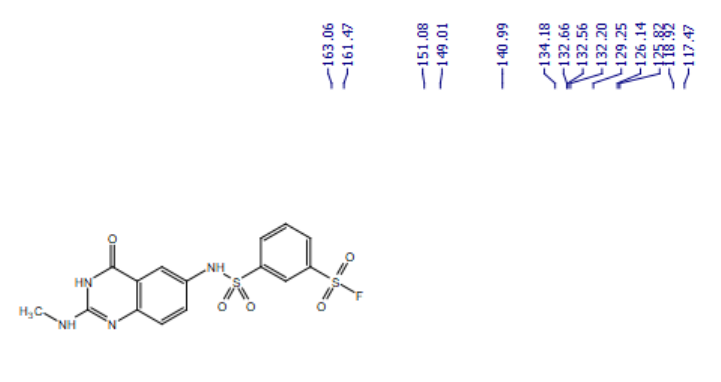

iv

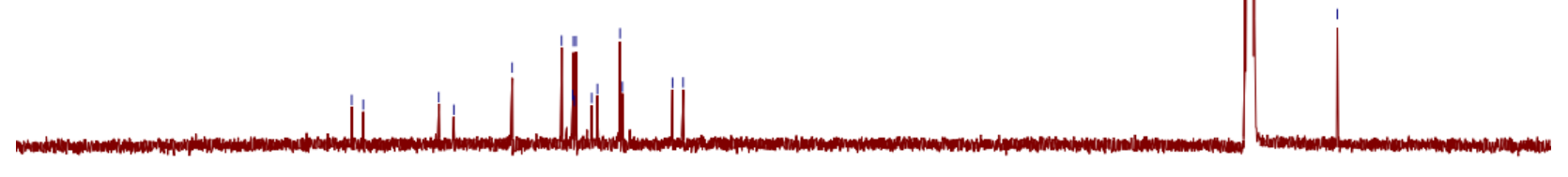

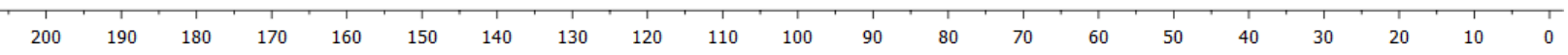




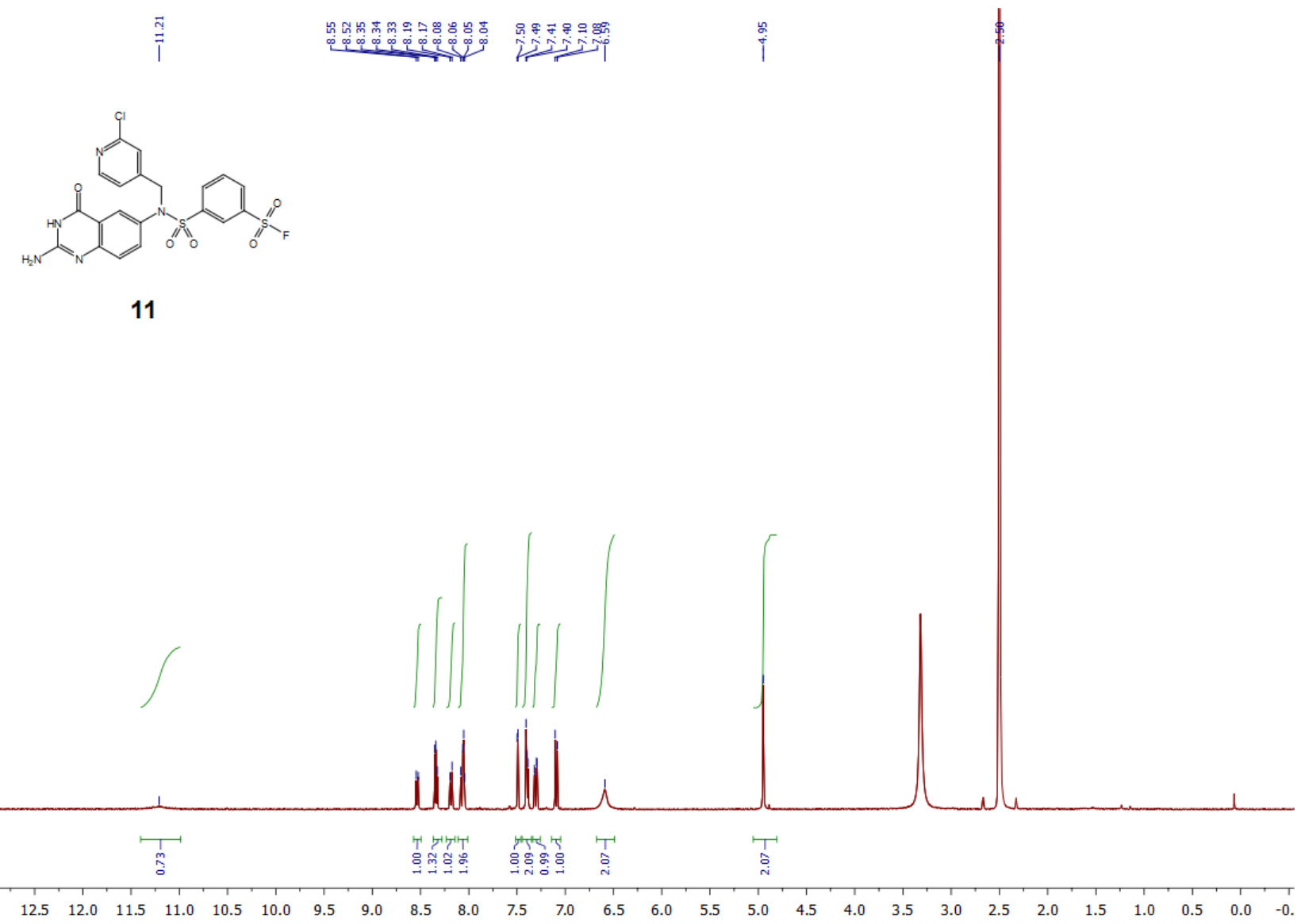




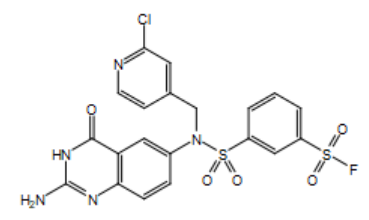

11

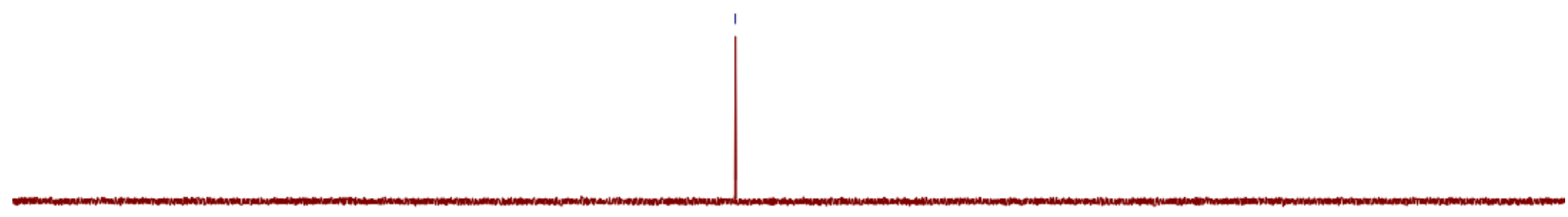




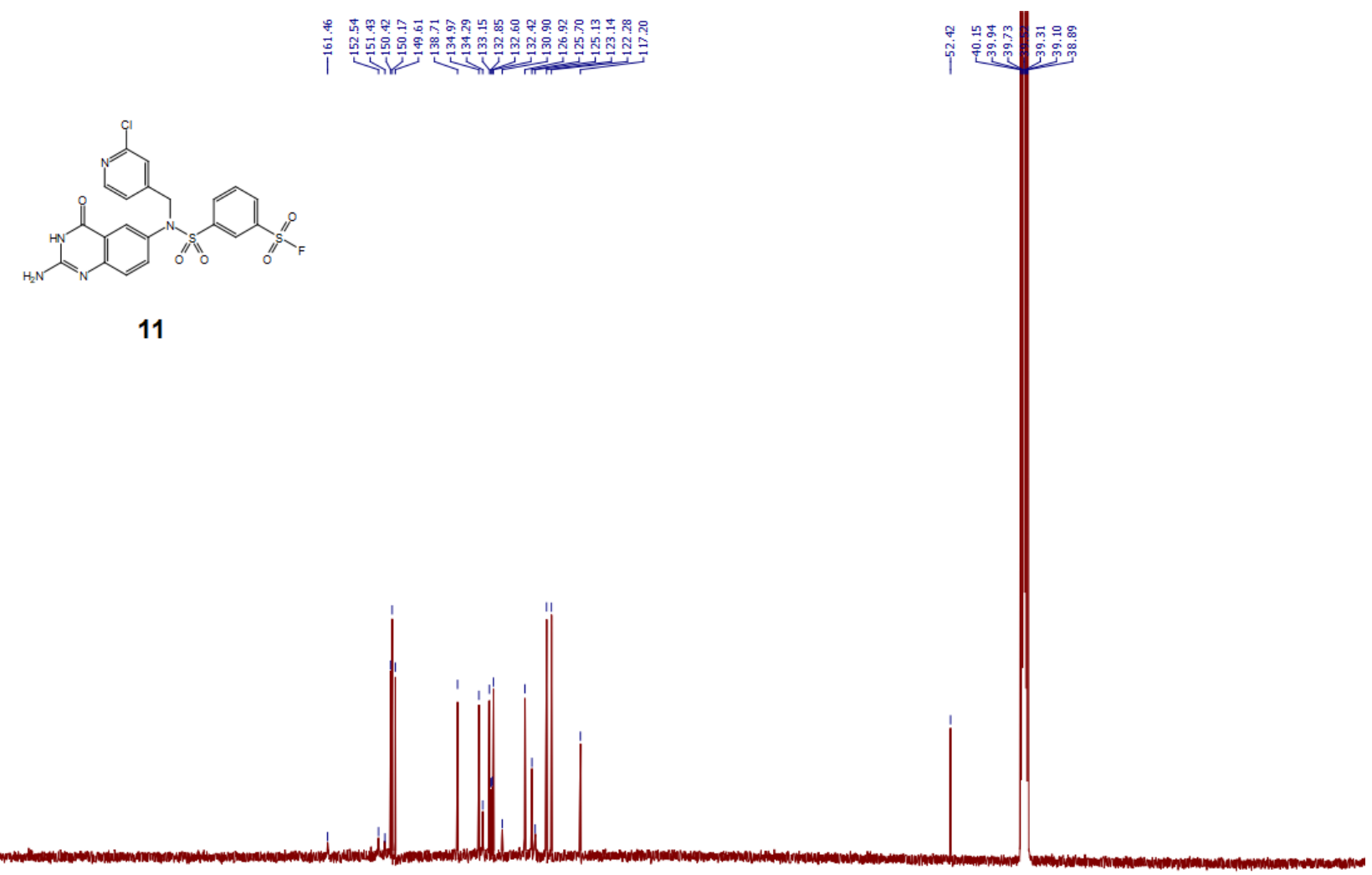

$\begin{array}{llllllllllllllllllllllllllll}210 & 200 & 190 & 180 & 170 & 160 & 150 & 140 & 130 & 120 & 110 & 100 & 90 & 80 & 70 & 60 & 50 & 40 & 30 & 20 & 10 & 0 & -10 & -2\end{array}$ 


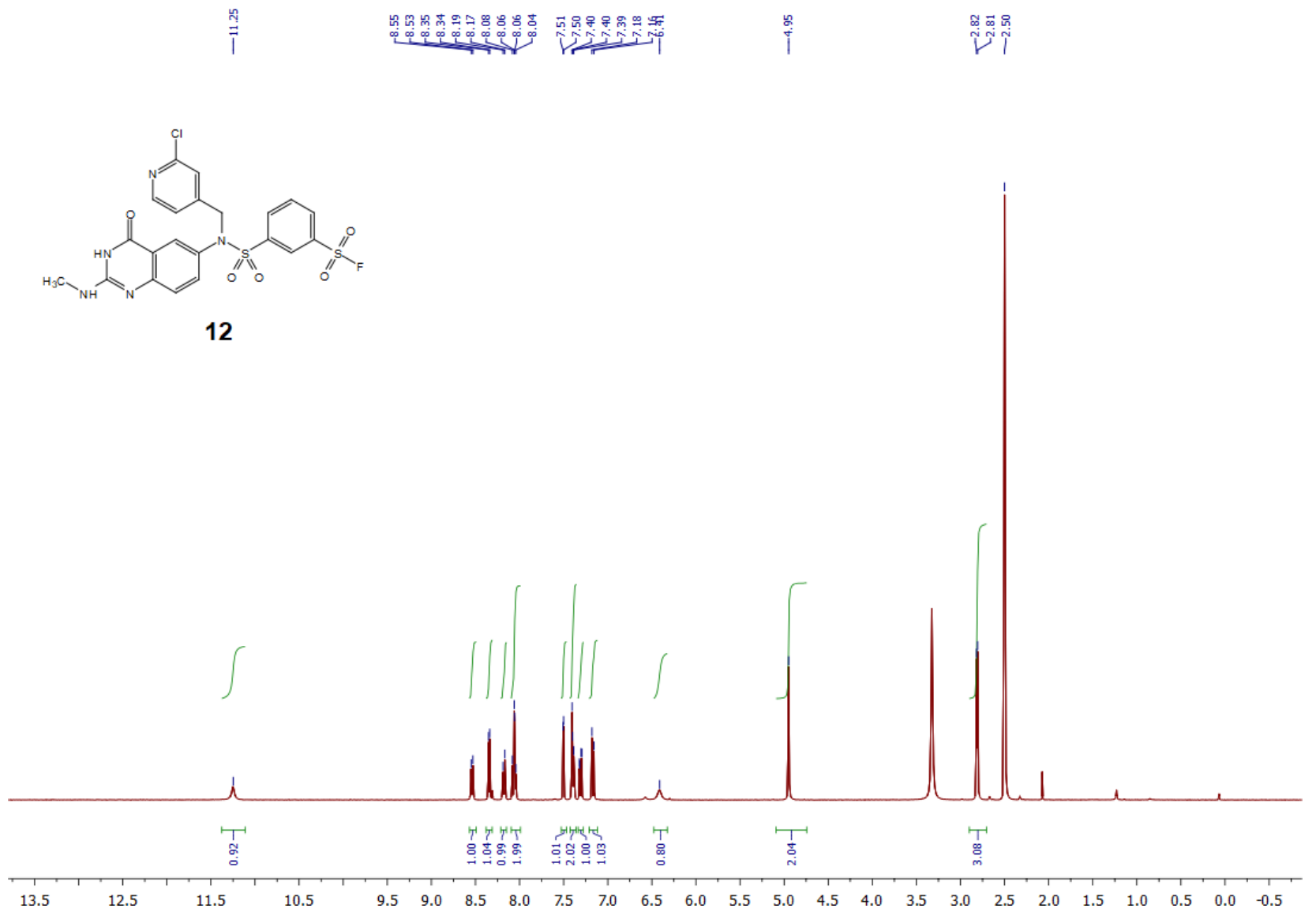



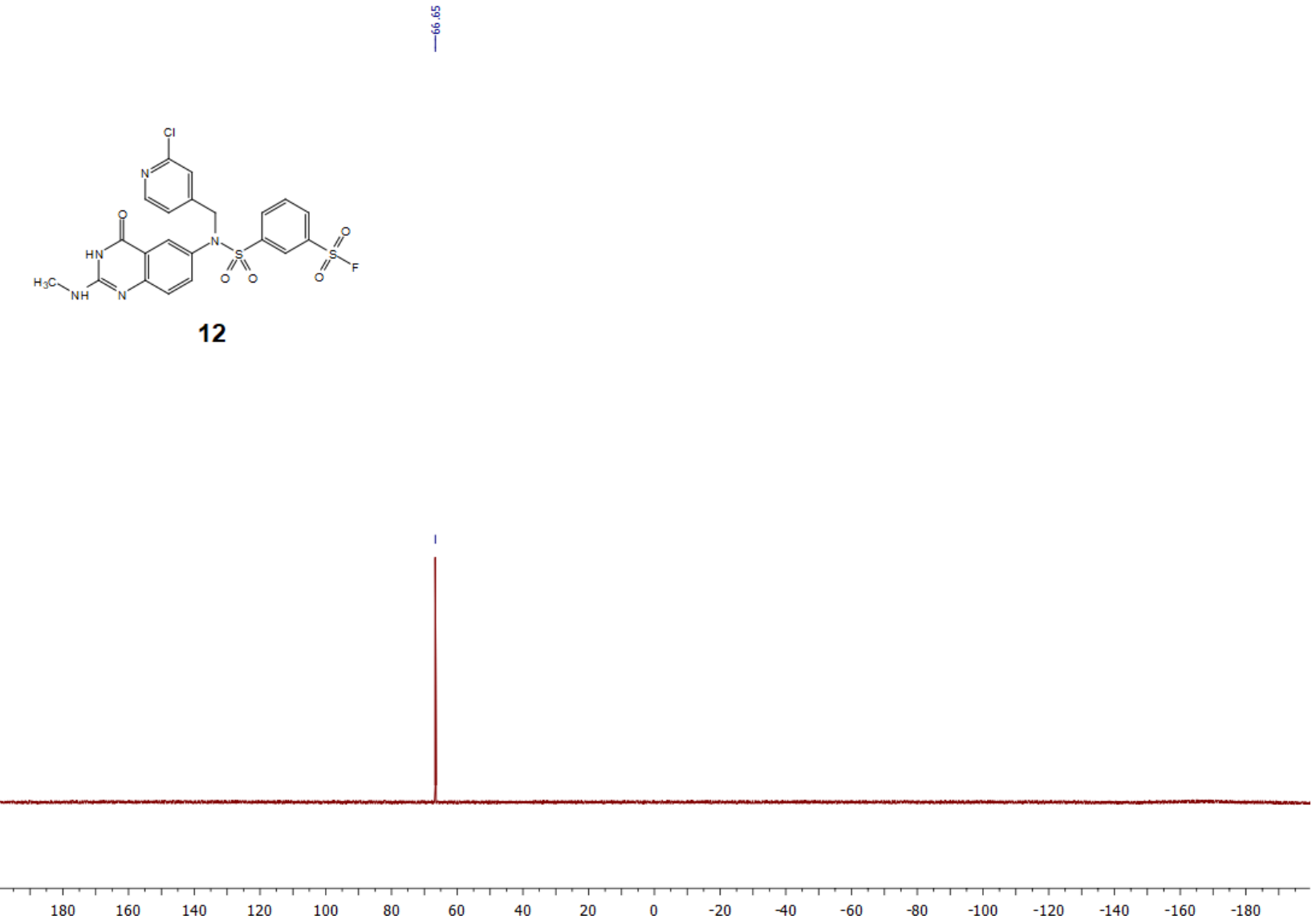


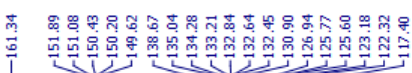

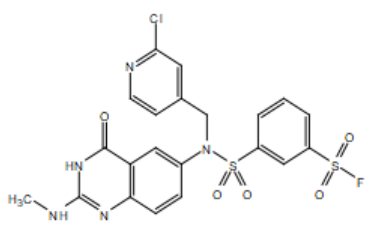

12

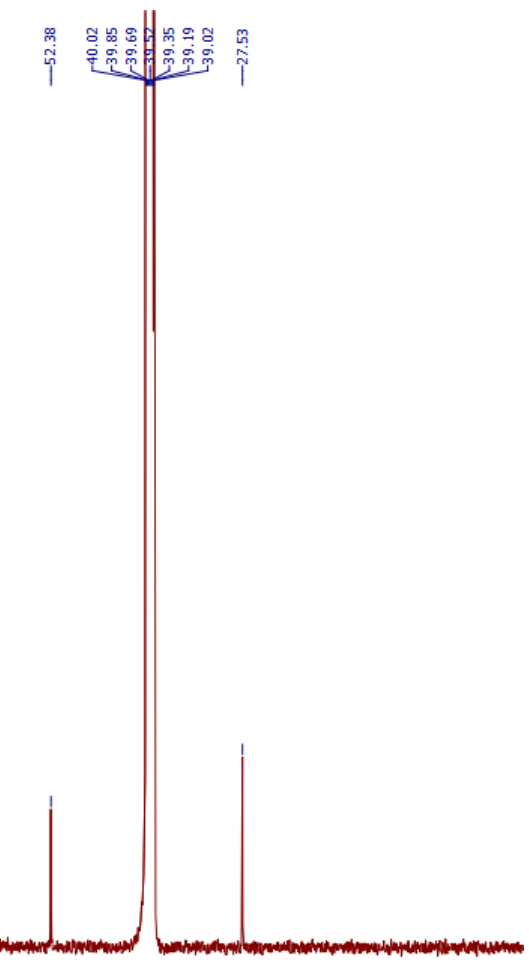




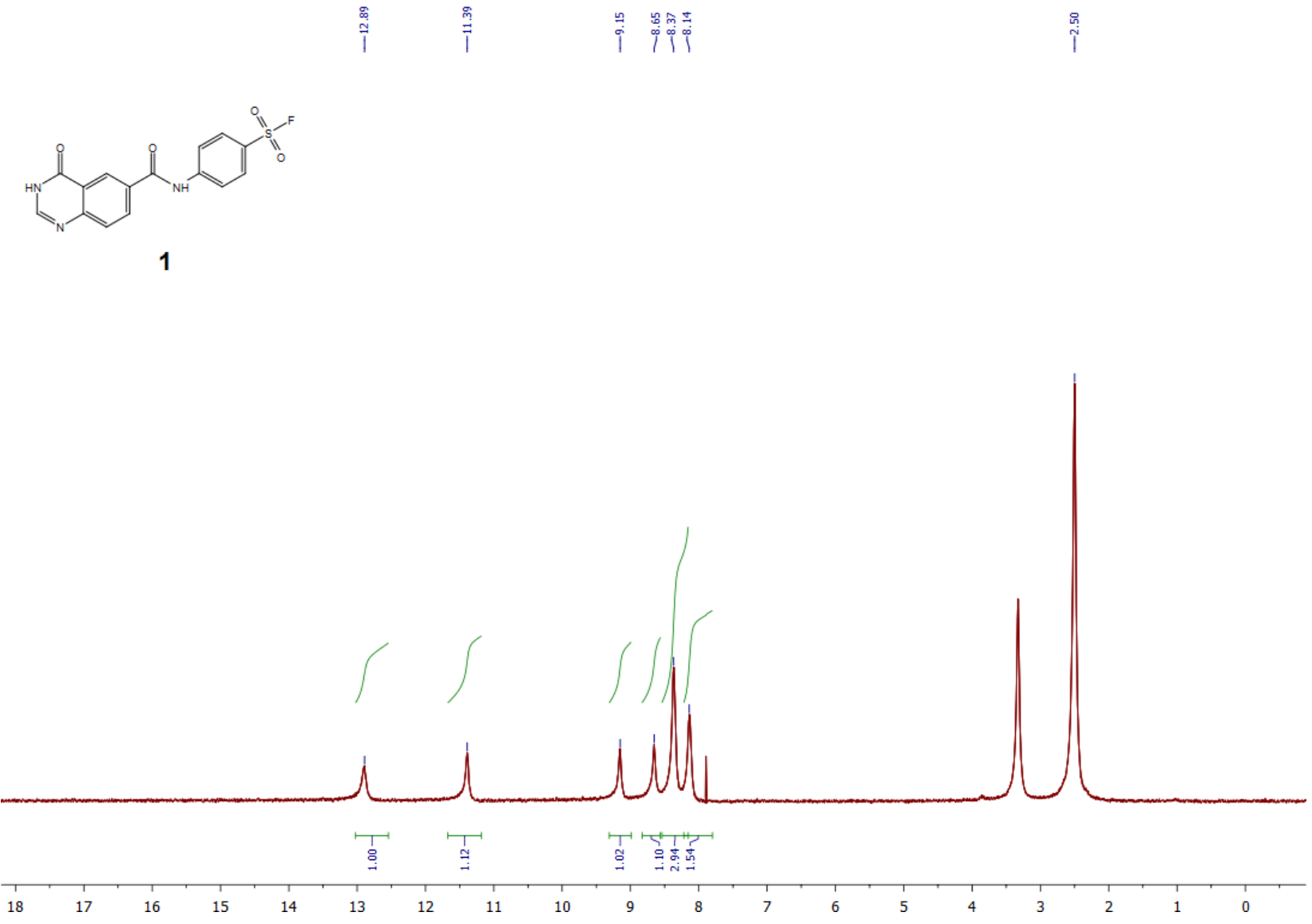




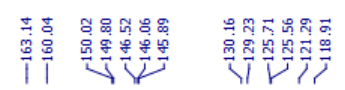
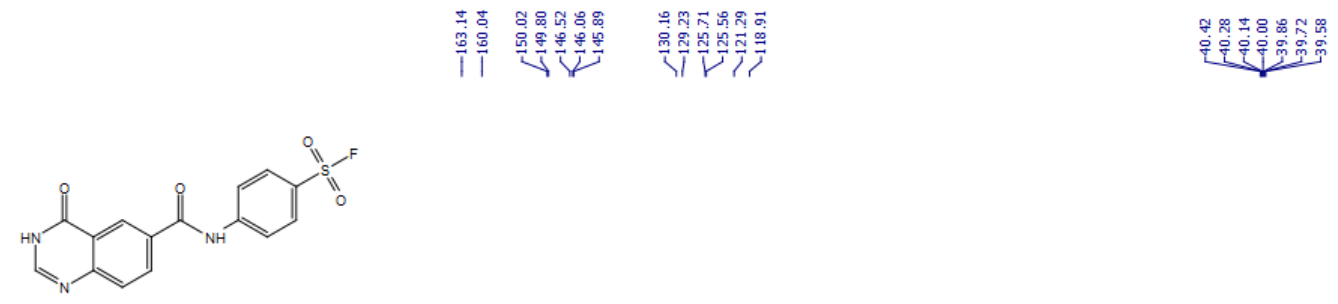

1

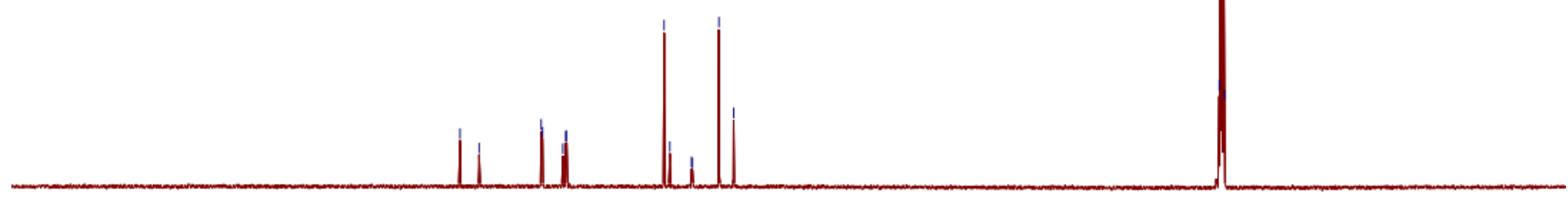

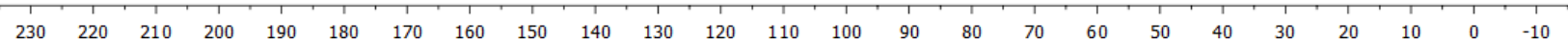




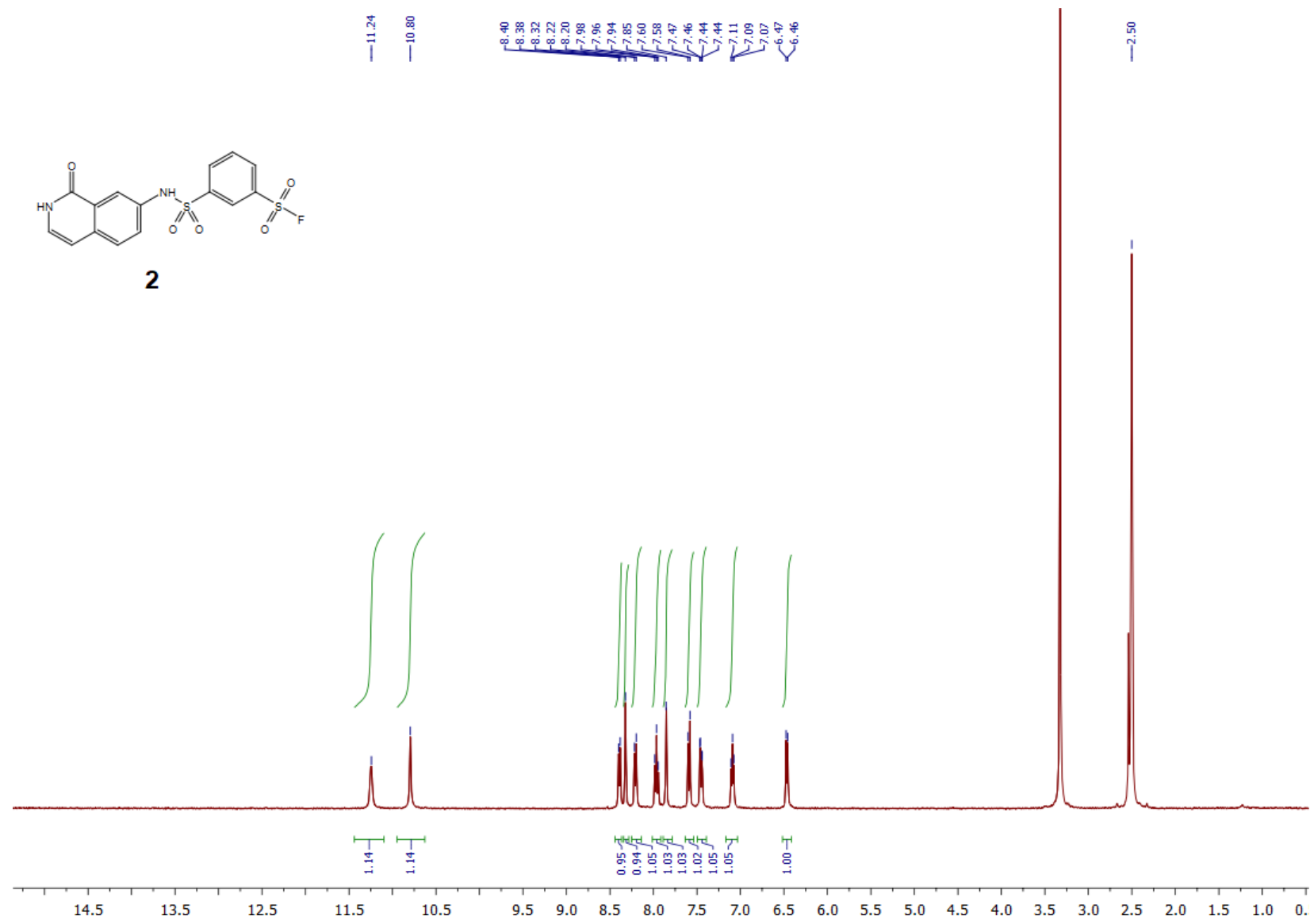



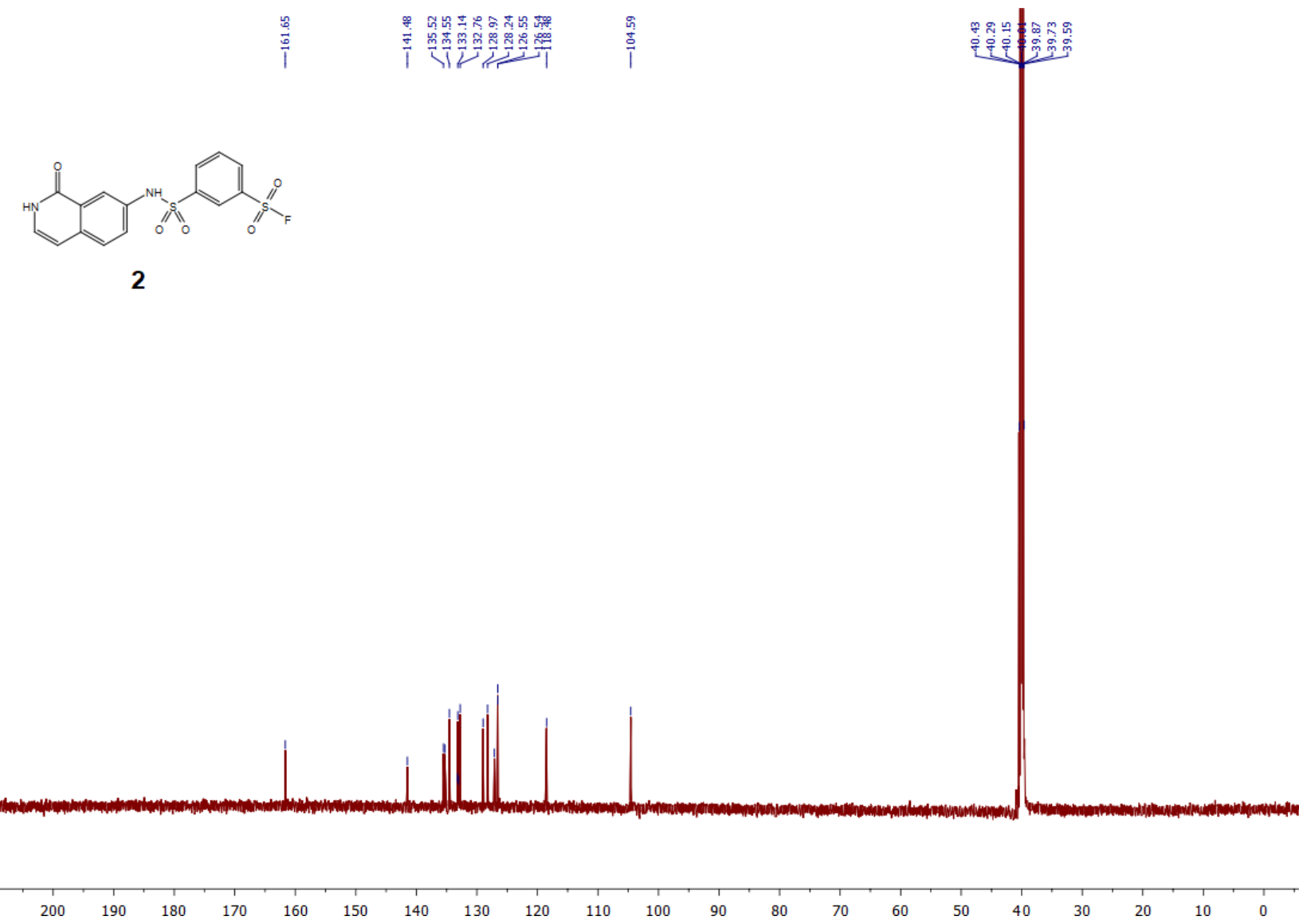


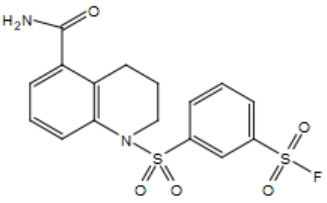

3

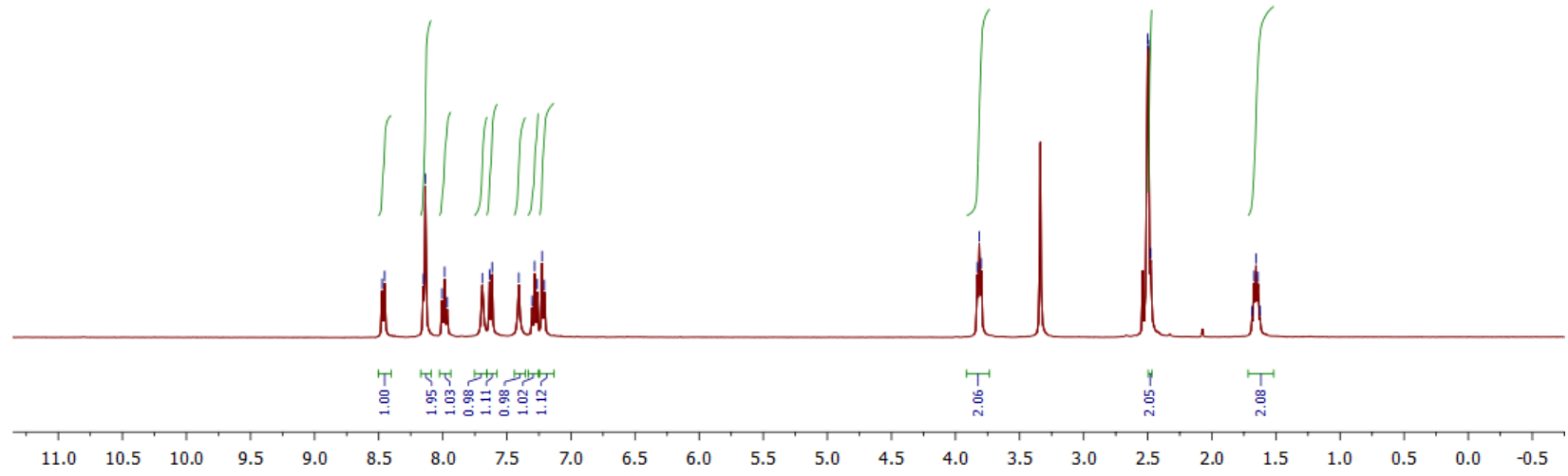



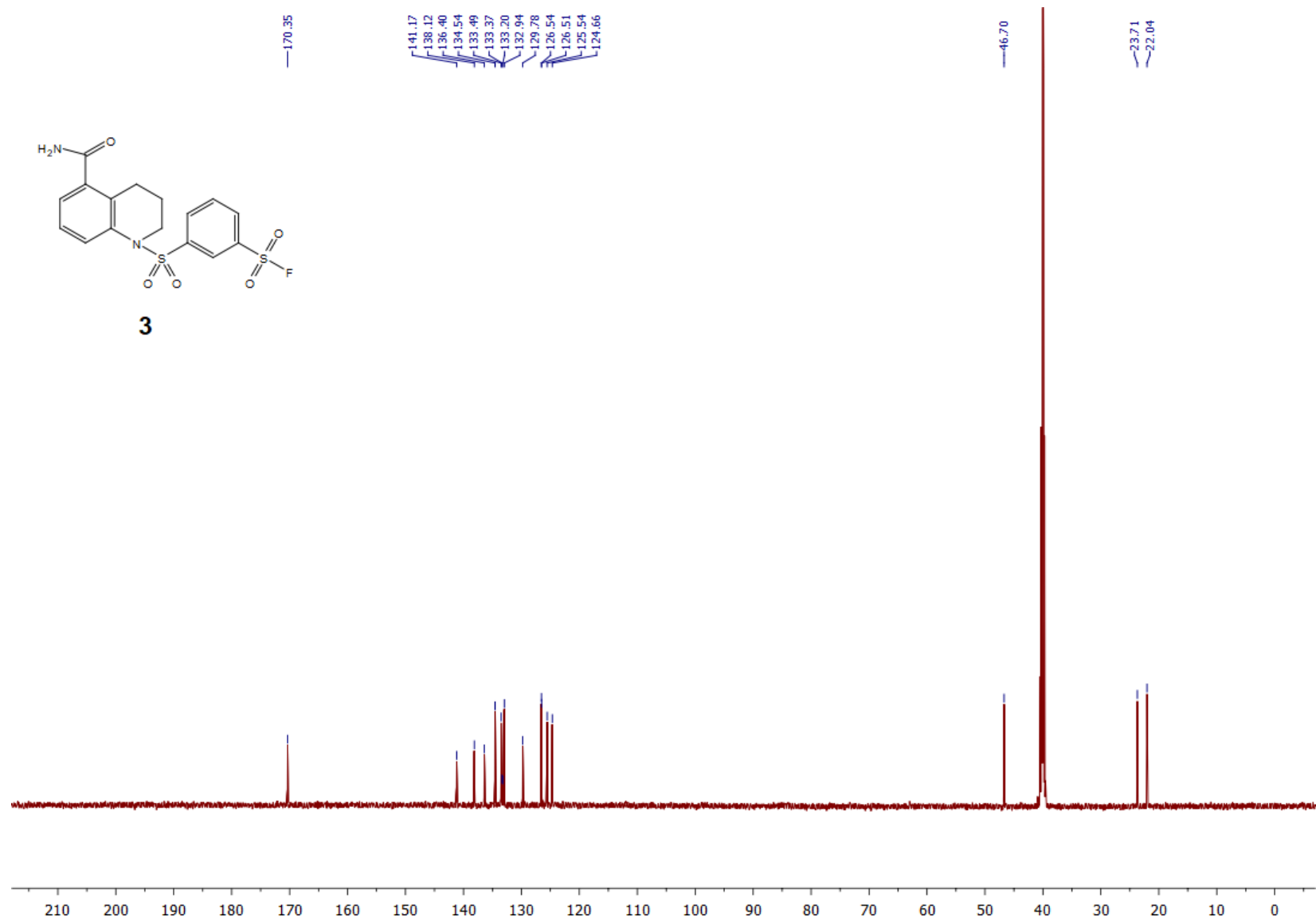


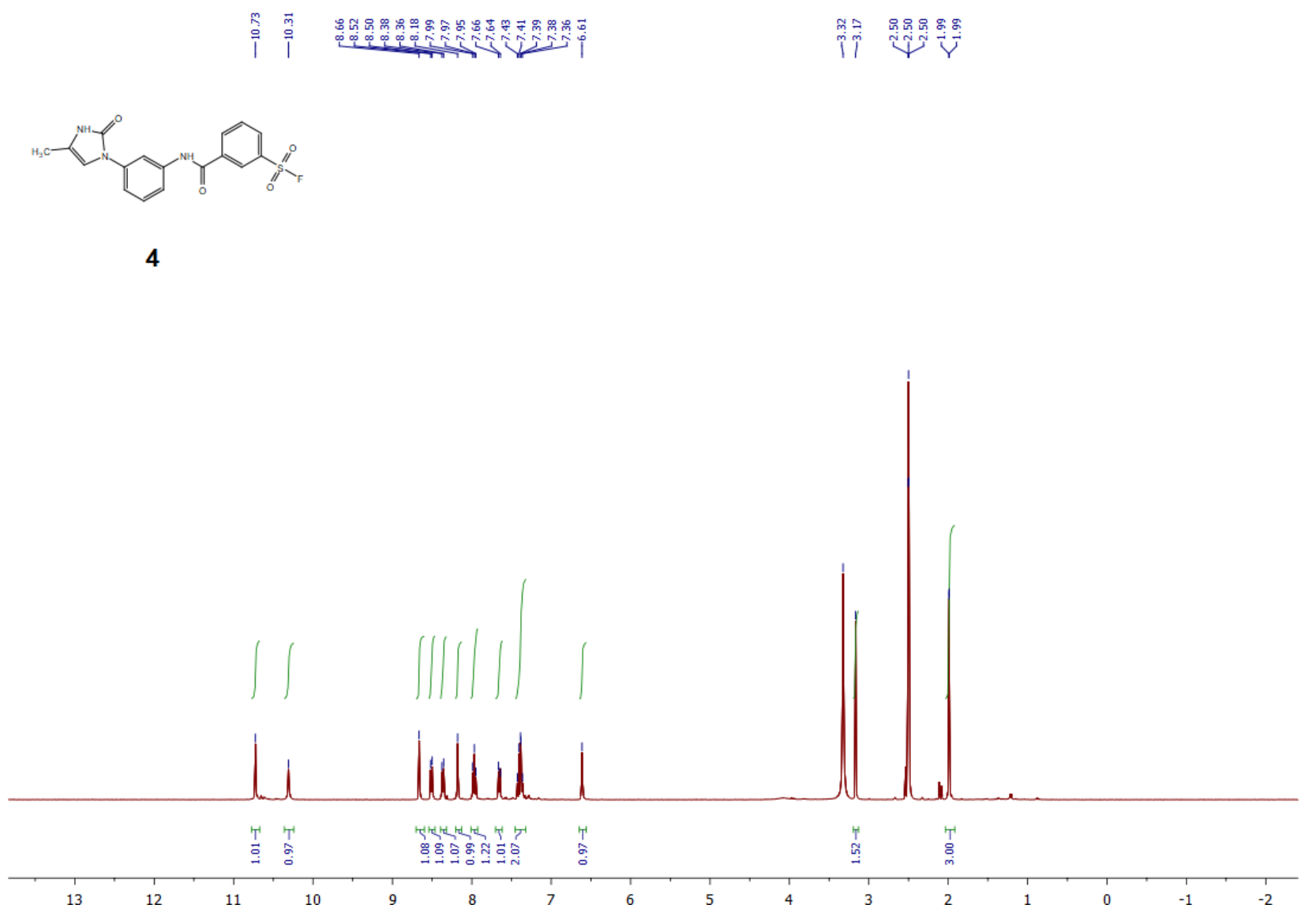



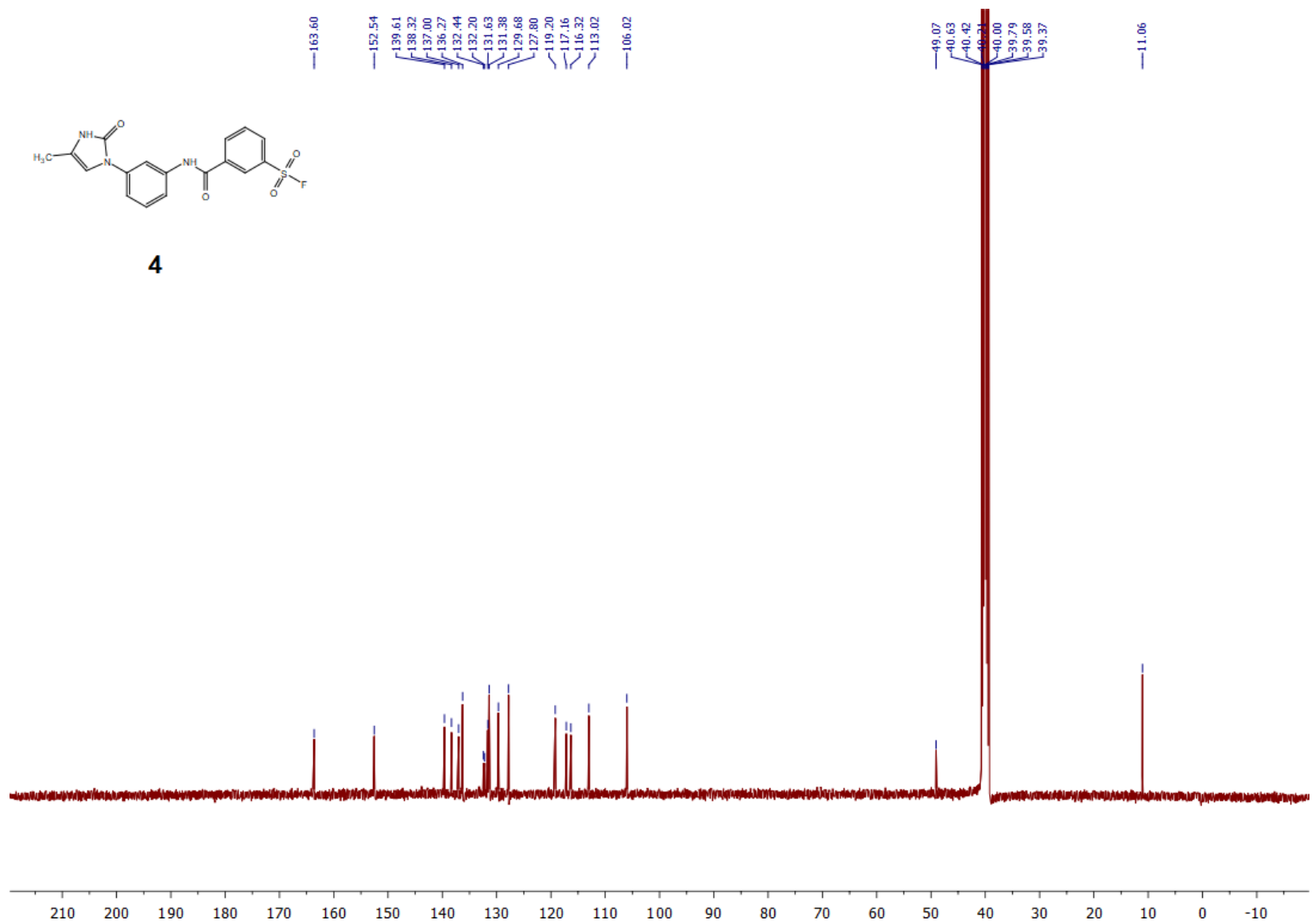

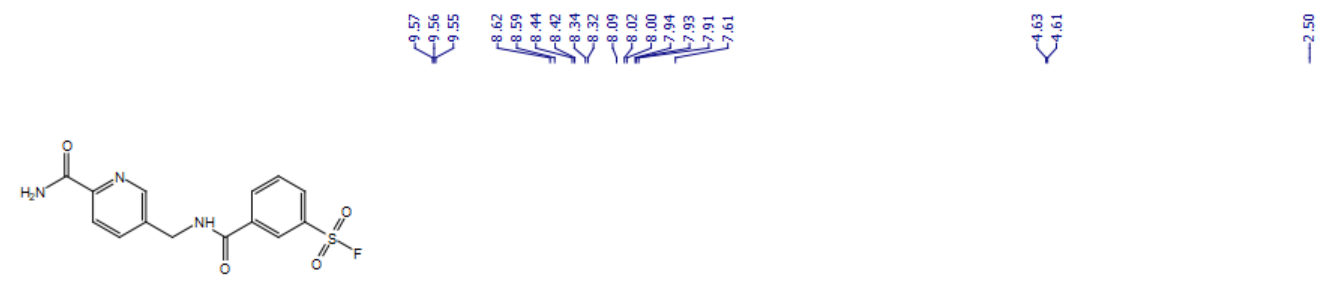

5

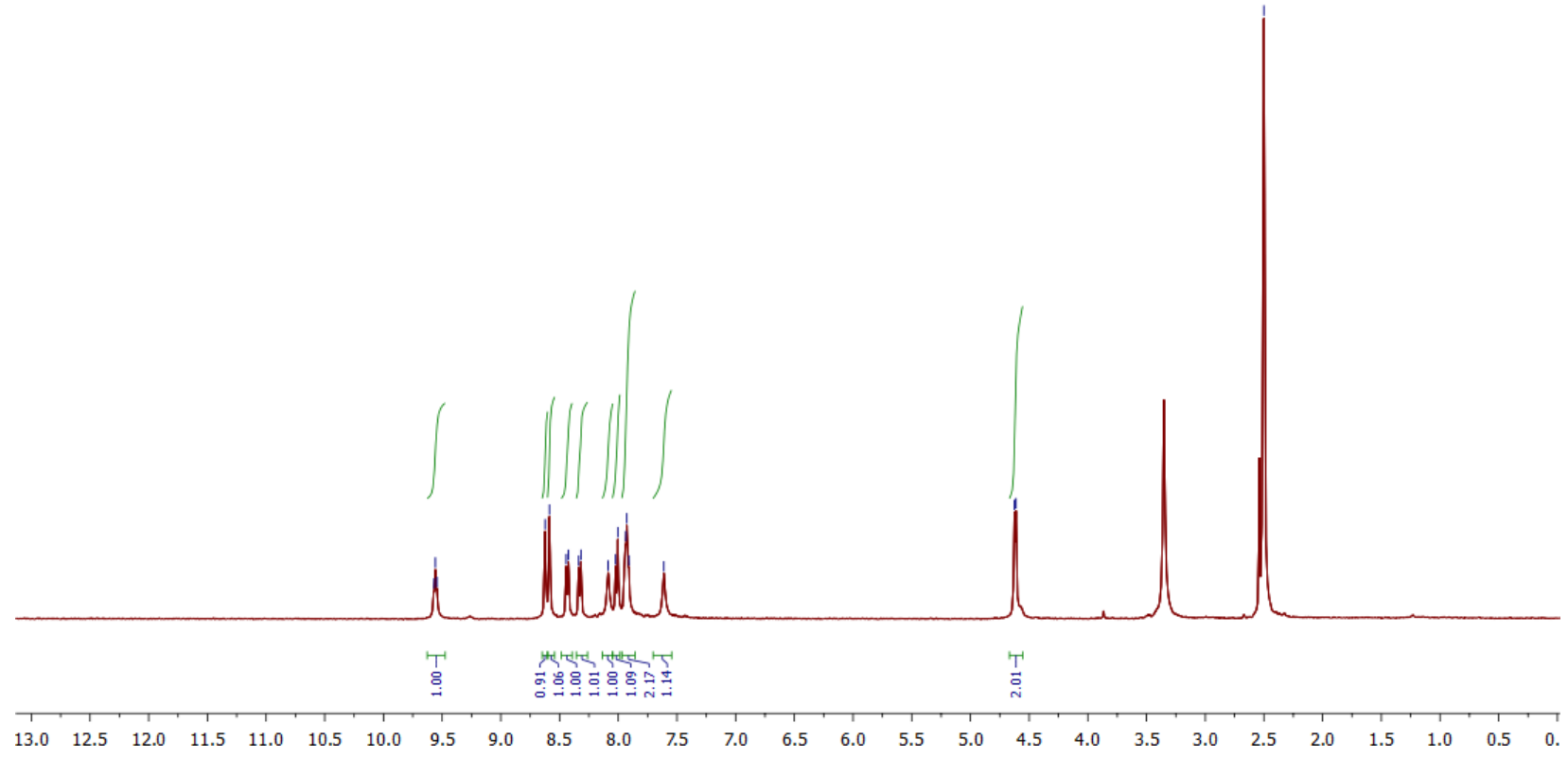



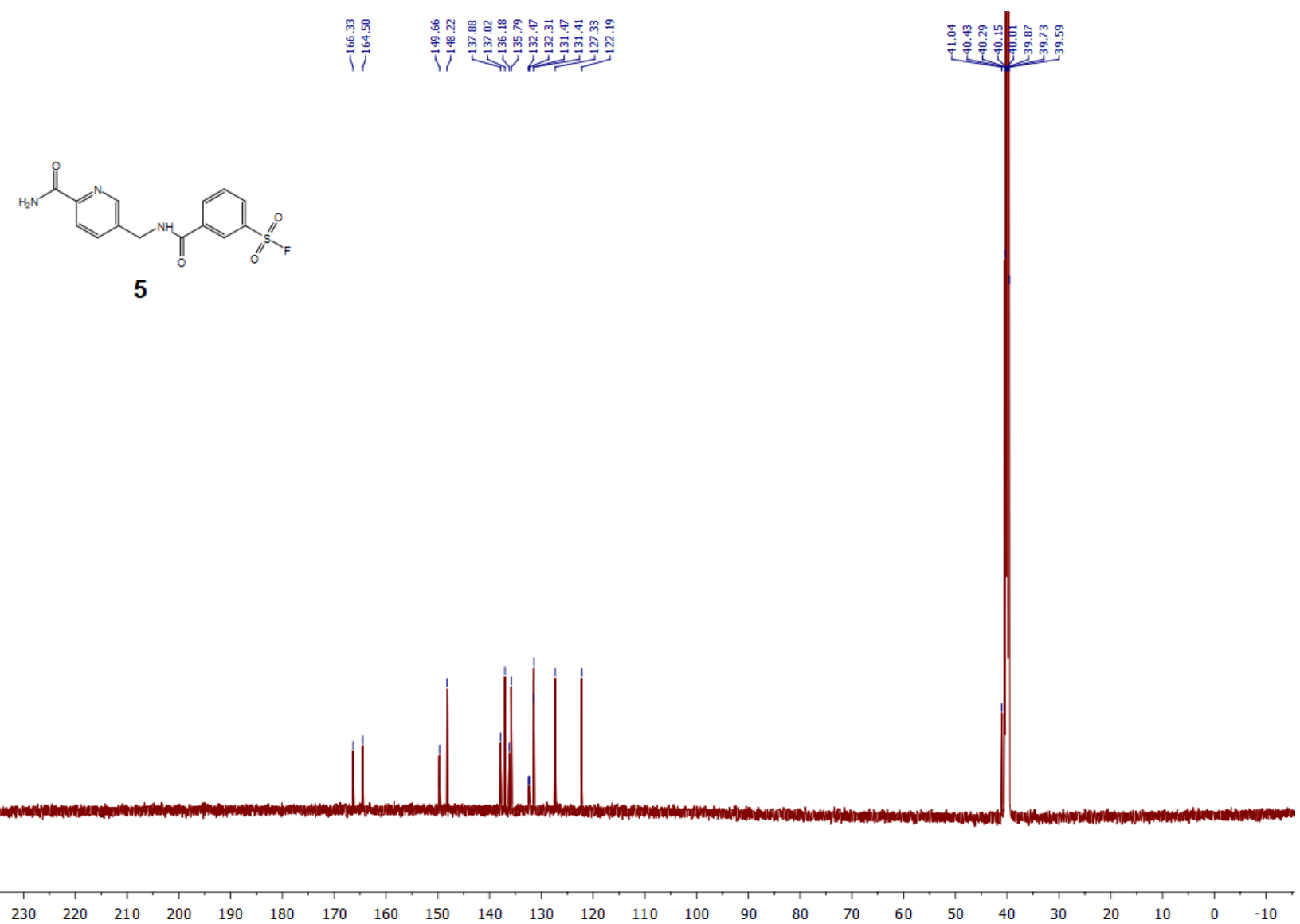


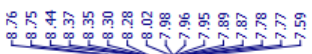

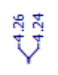

iึ

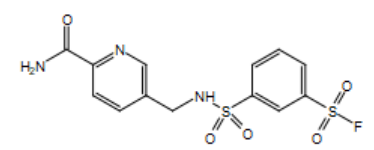

6

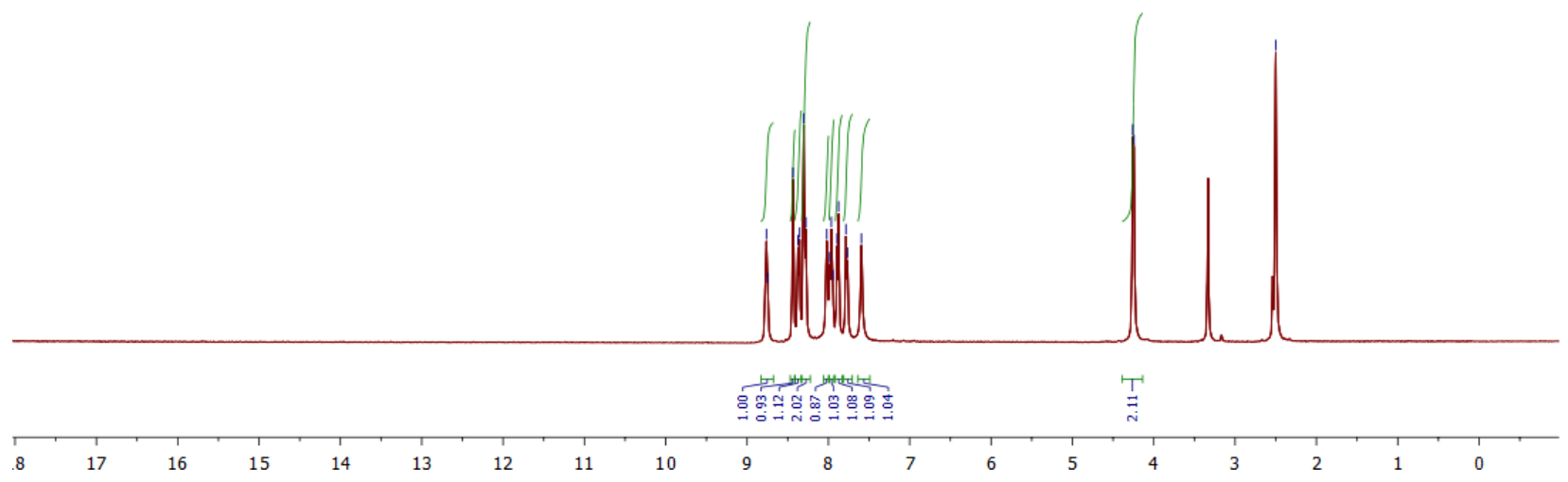

55 


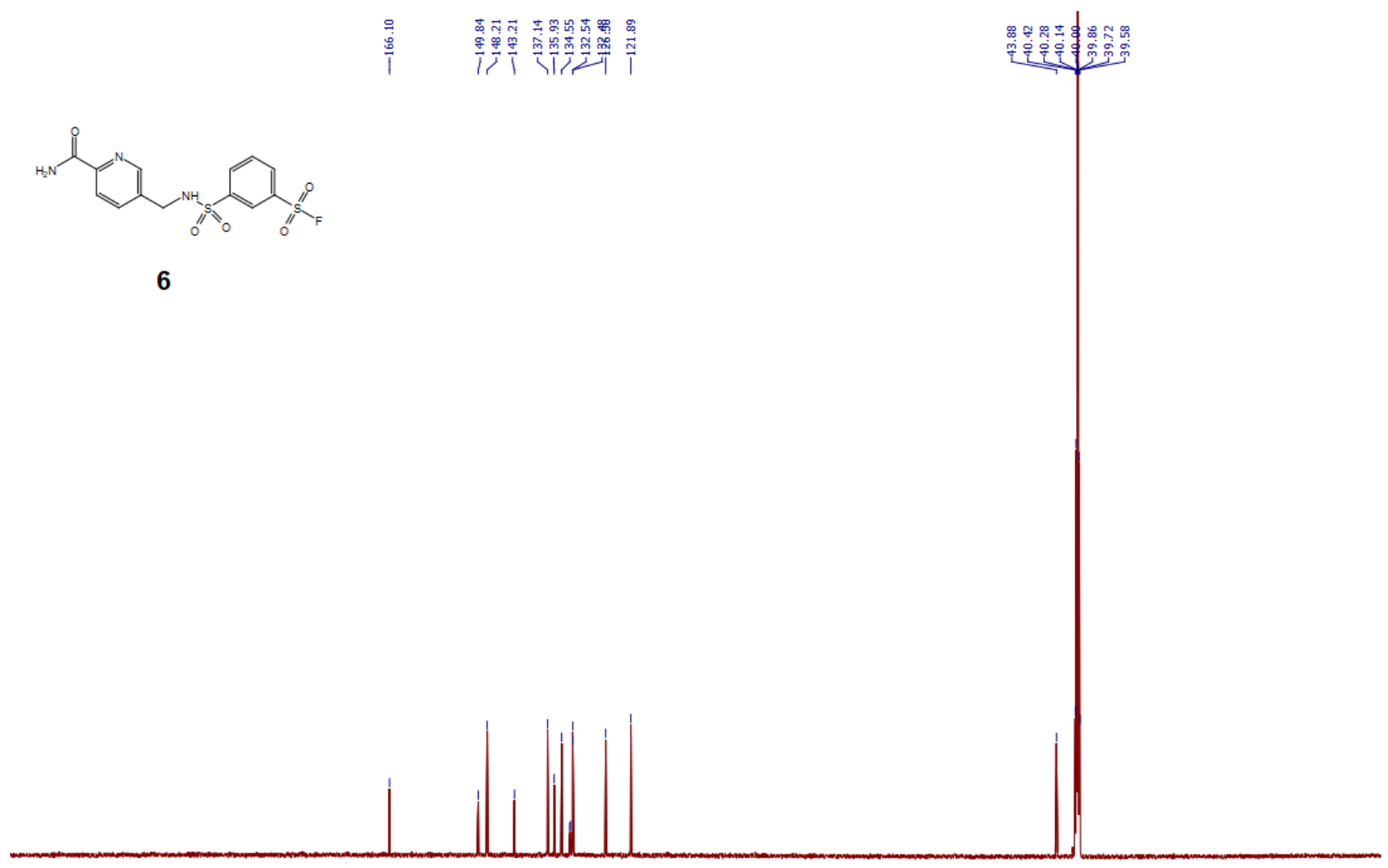

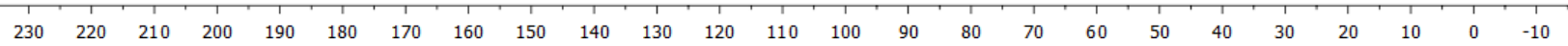




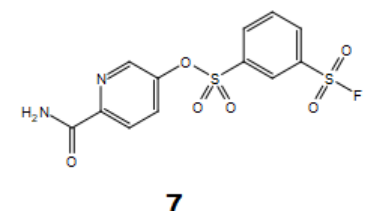

\section{7}

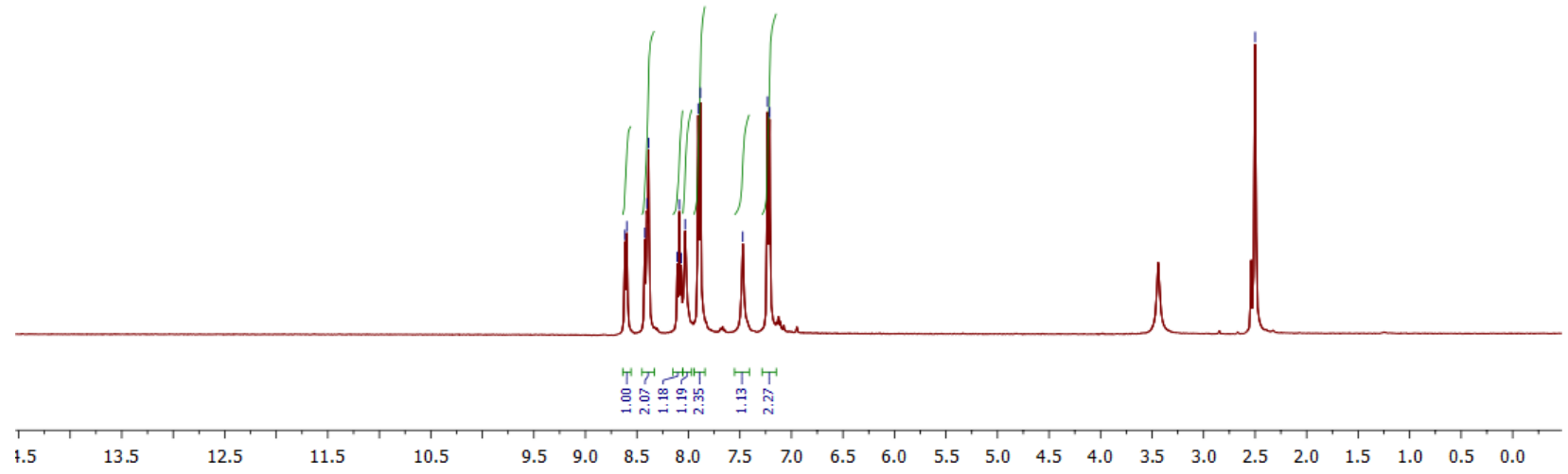




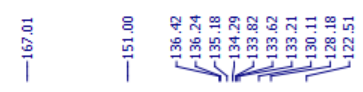

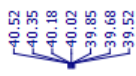

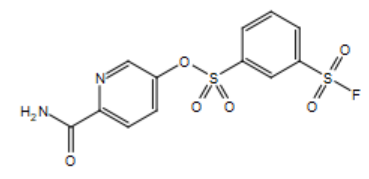

7

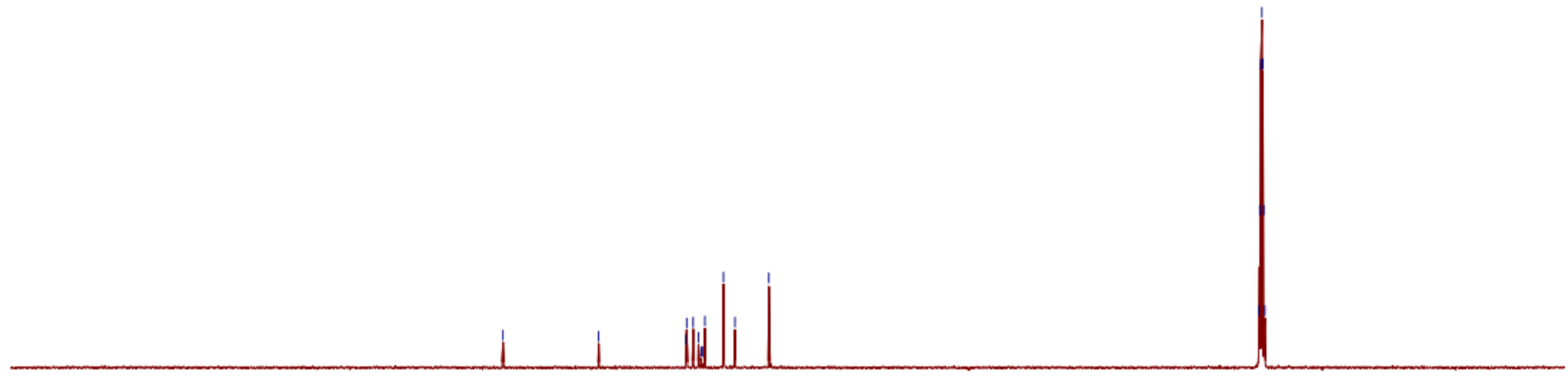

$\begin{array}{llllllllllllllllllllllllllll}240 & 230 & 220 & 210 & 200 & 190 & 180 & 170 & 160 & 150 & 140 & 130 & 120 & 110 & 100 & 90 & 80 & 70 & 60 & 50 & 40 & 30 & 20 & 10 & 0 & -1\end{array}$ 

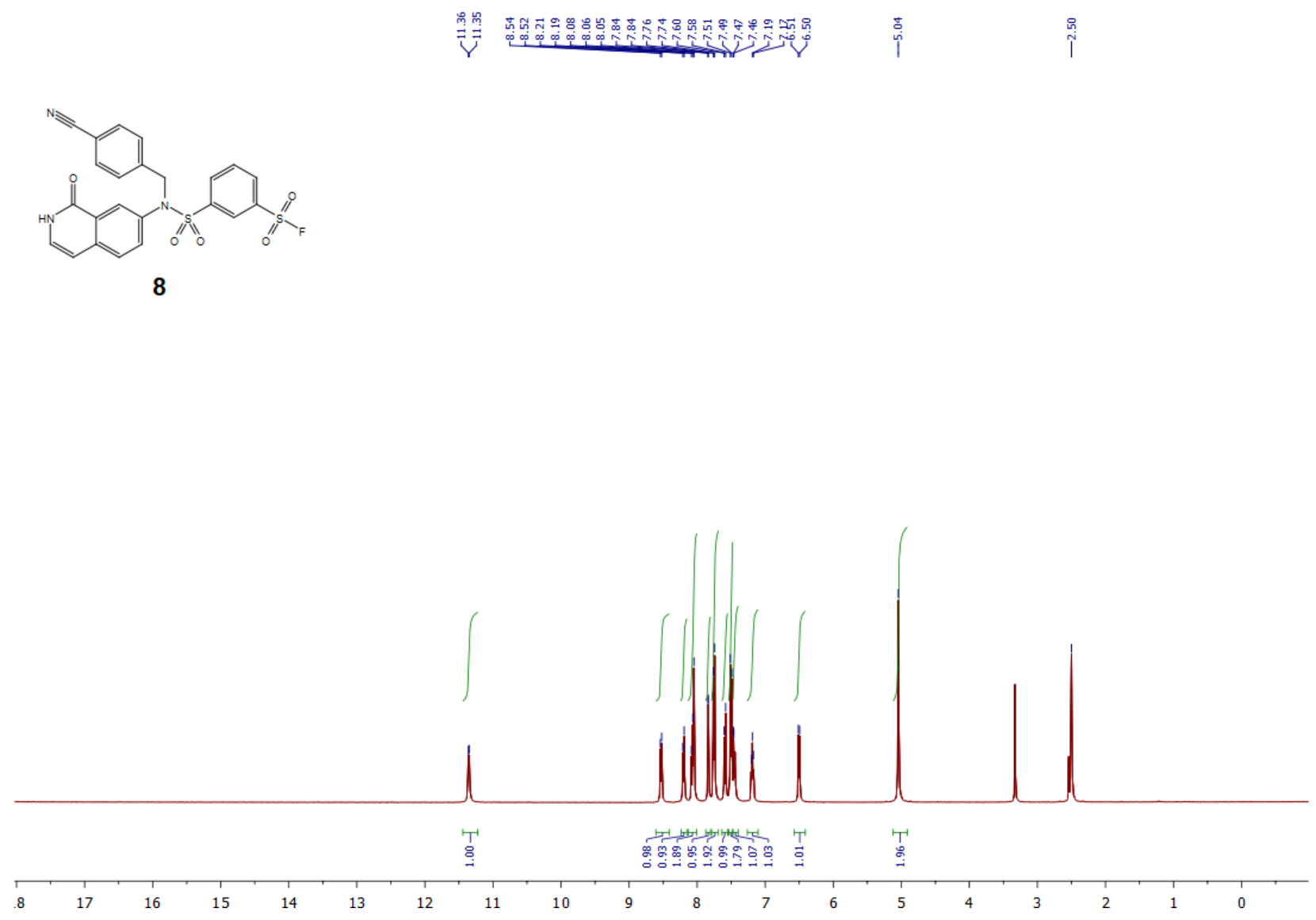

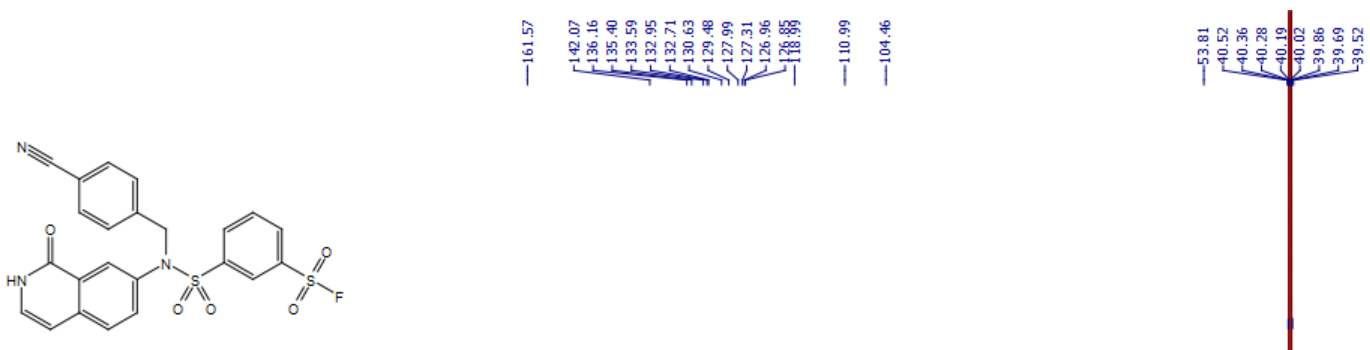

8

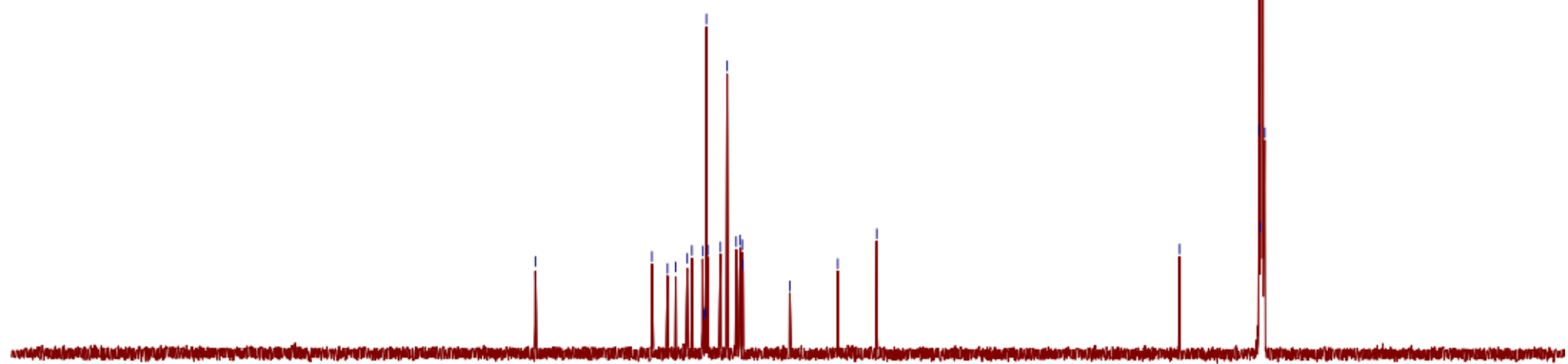

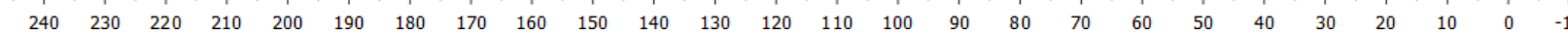




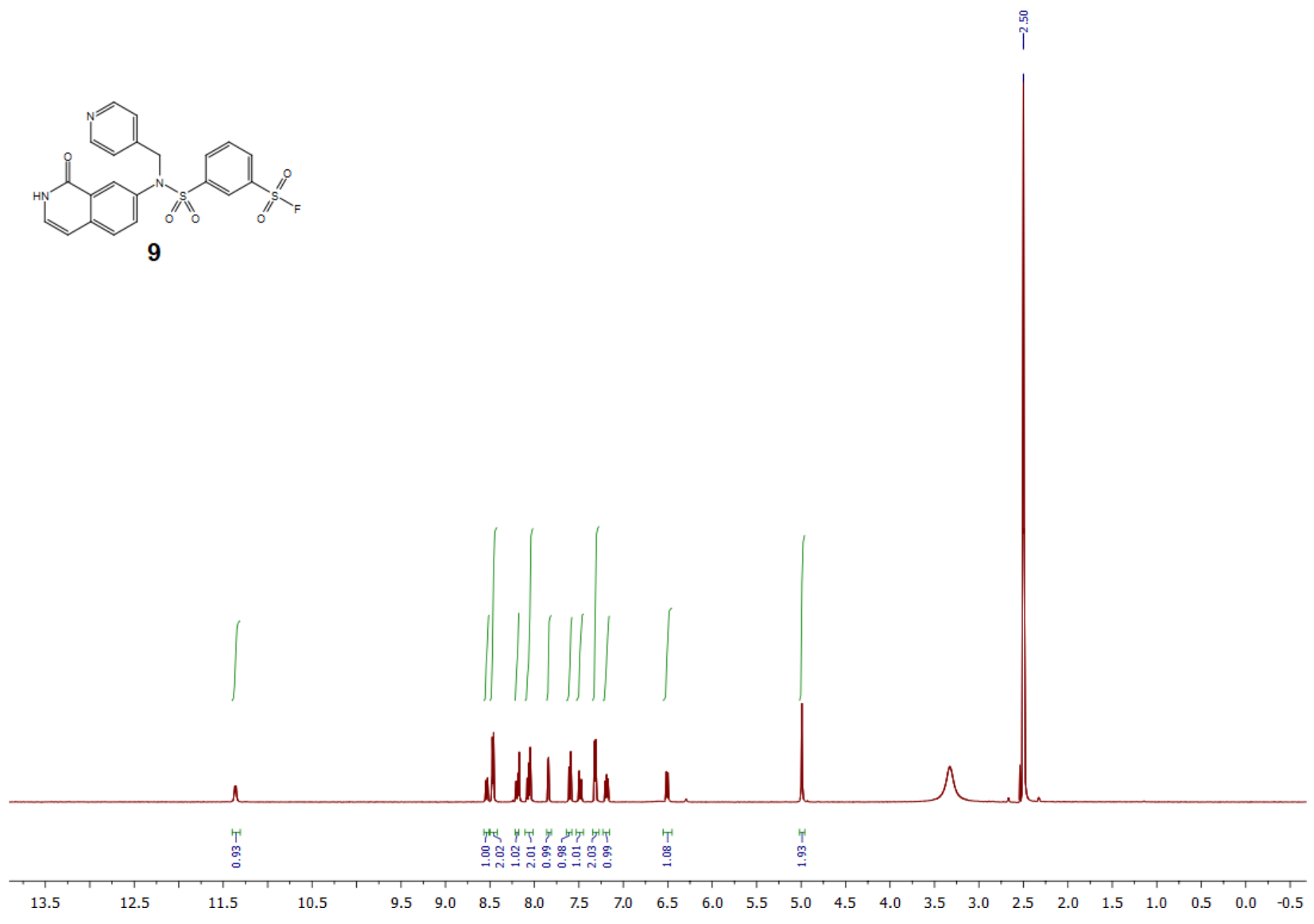



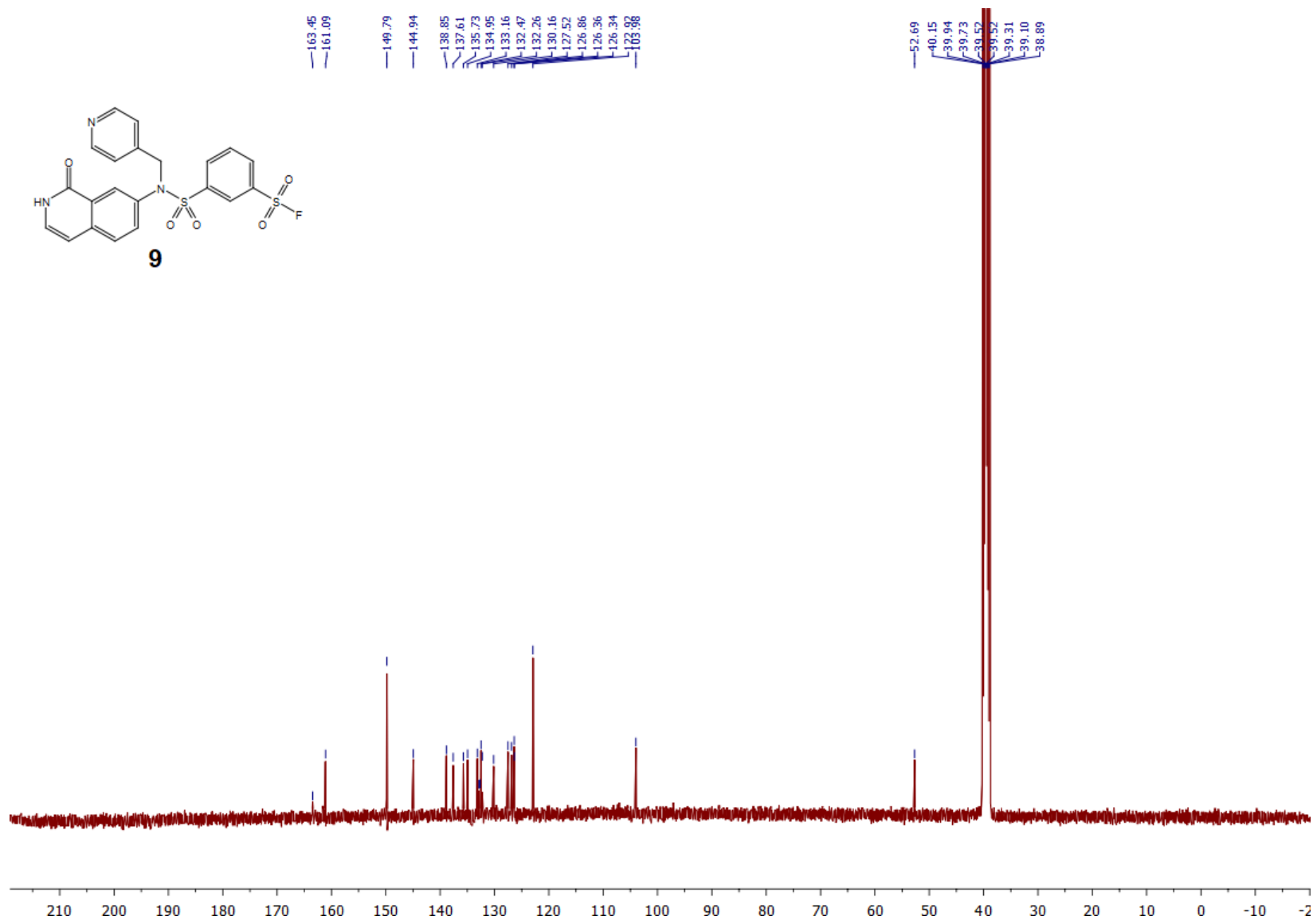

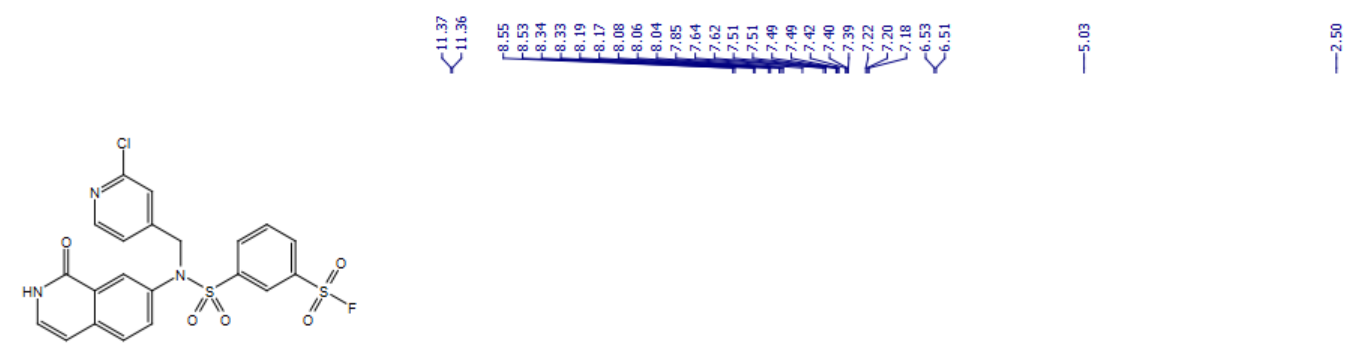

10

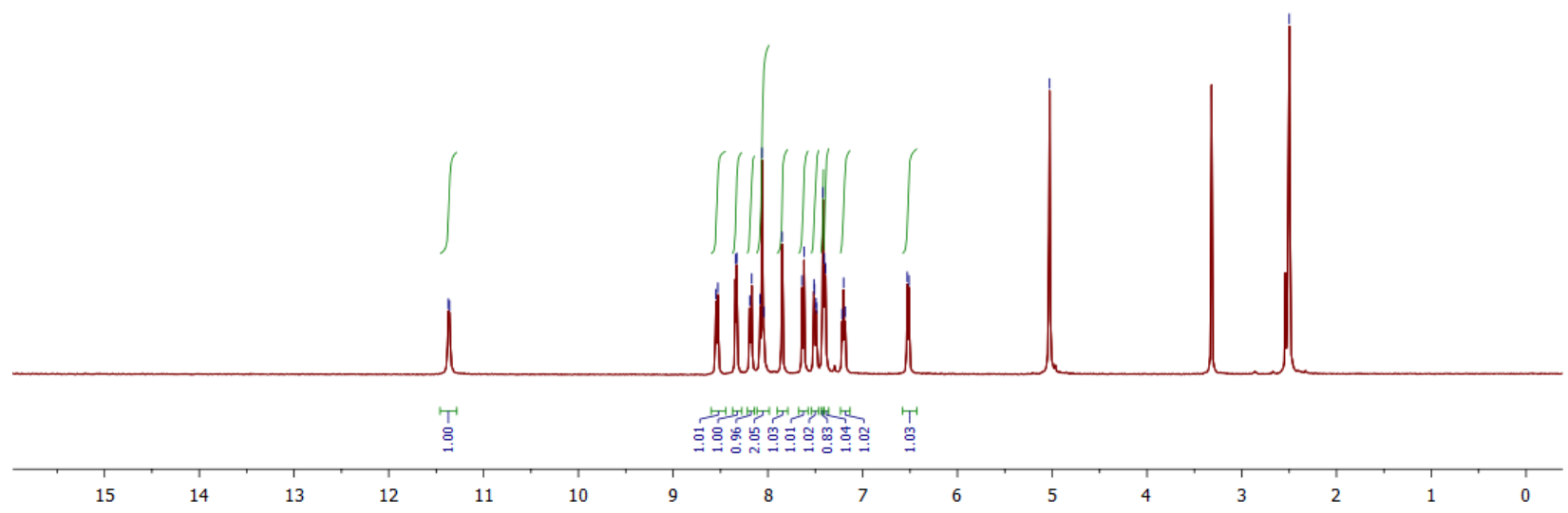




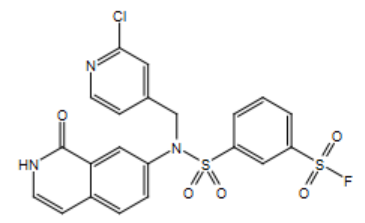

10
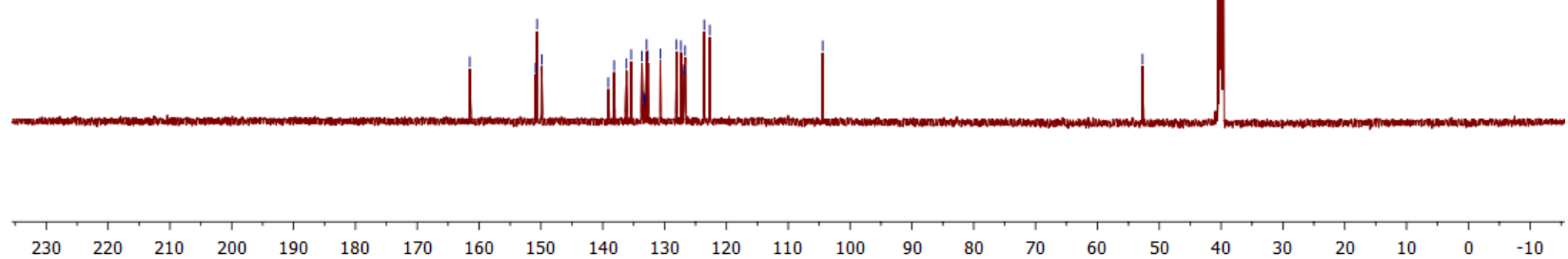


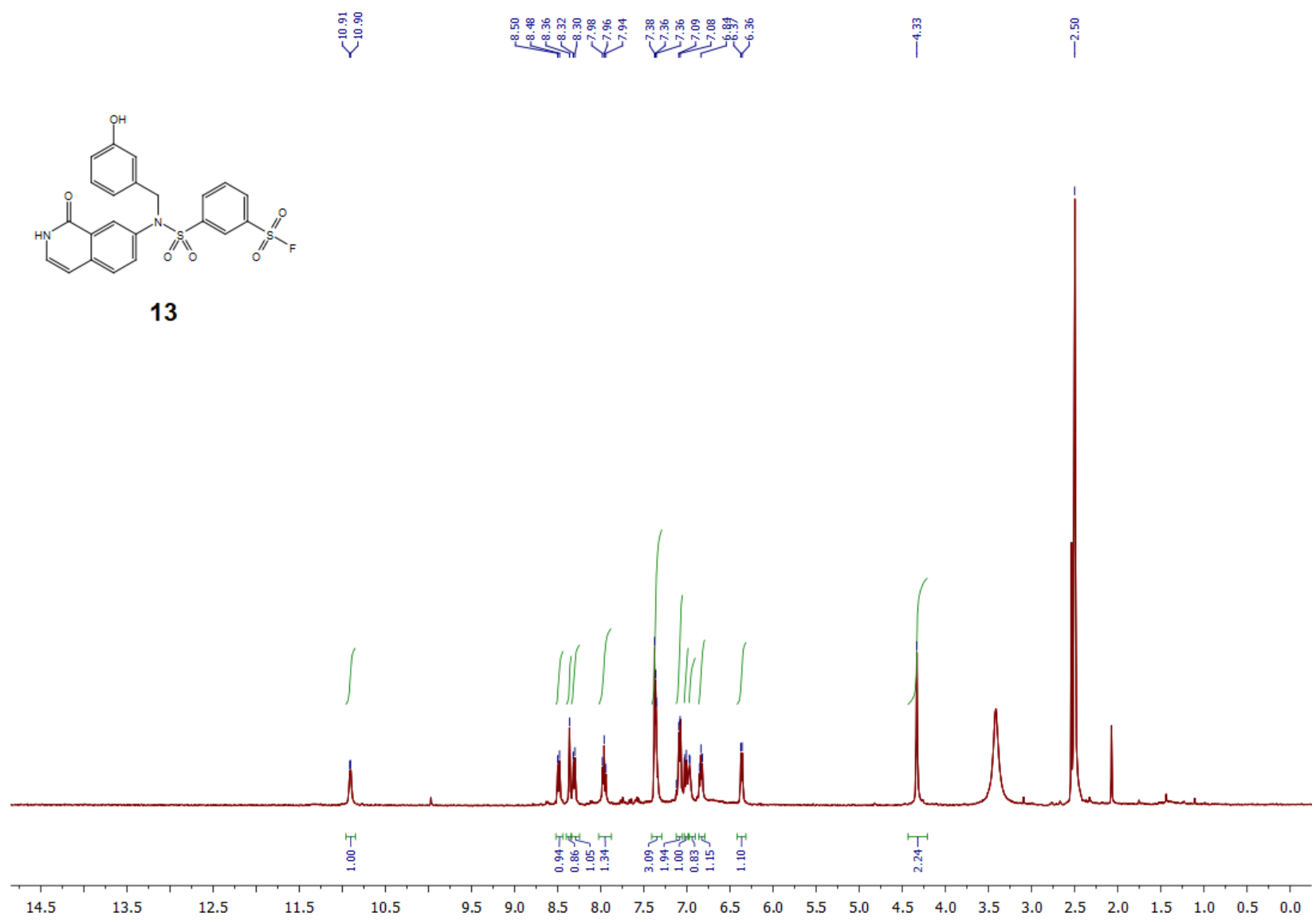




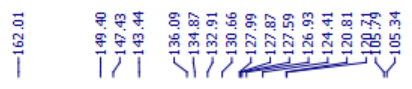

$\frac{9}{1}$

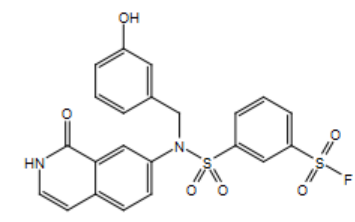

13
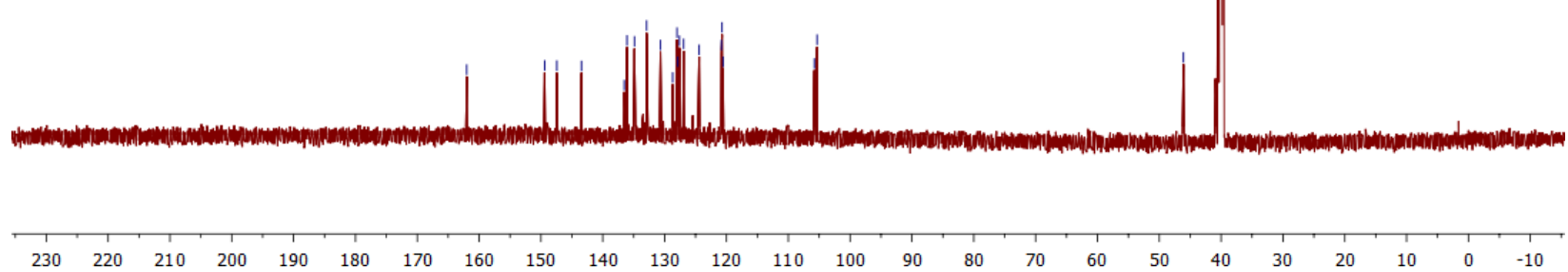

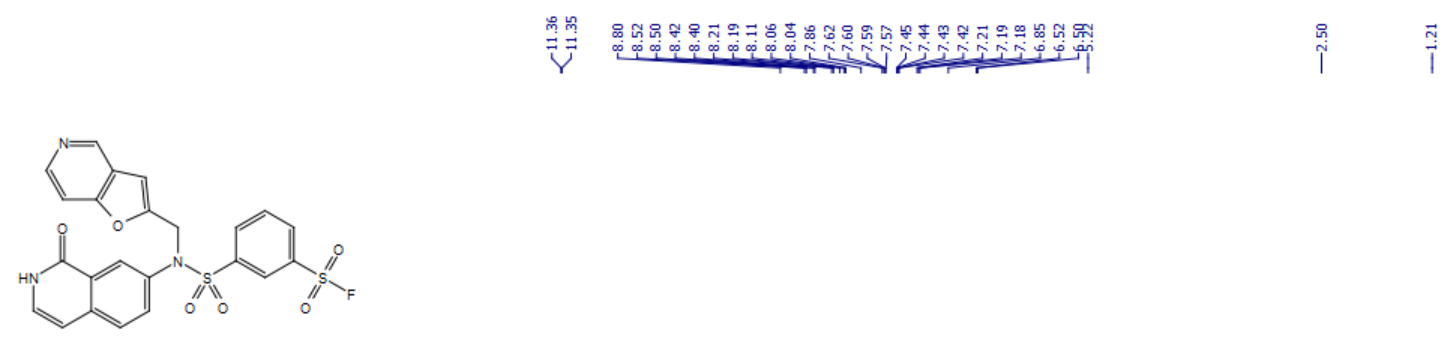

14

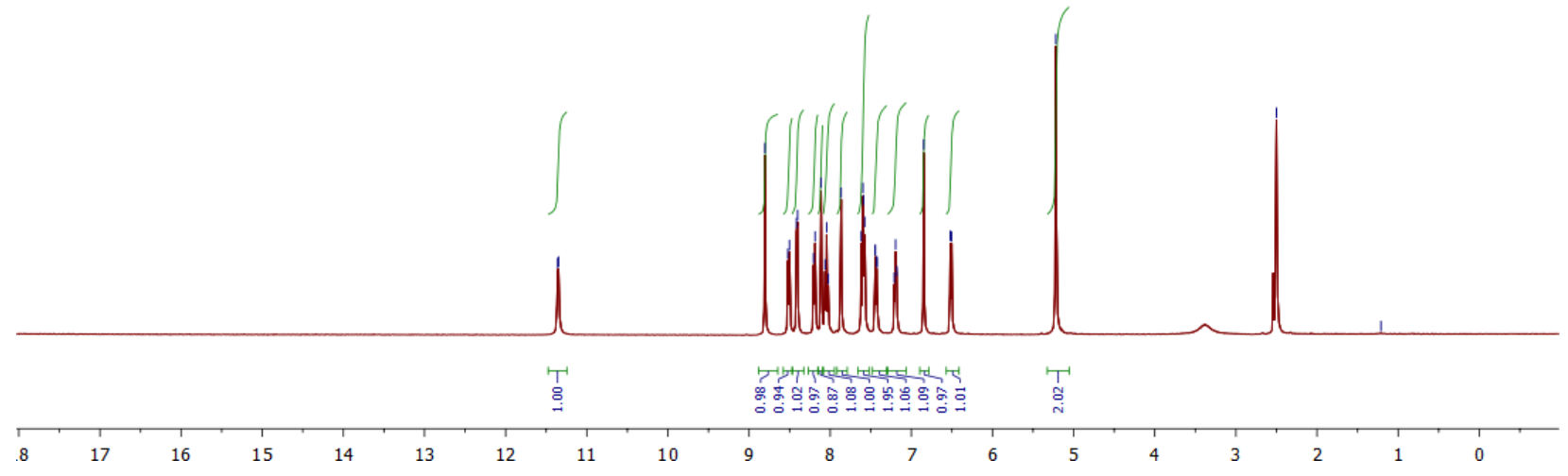



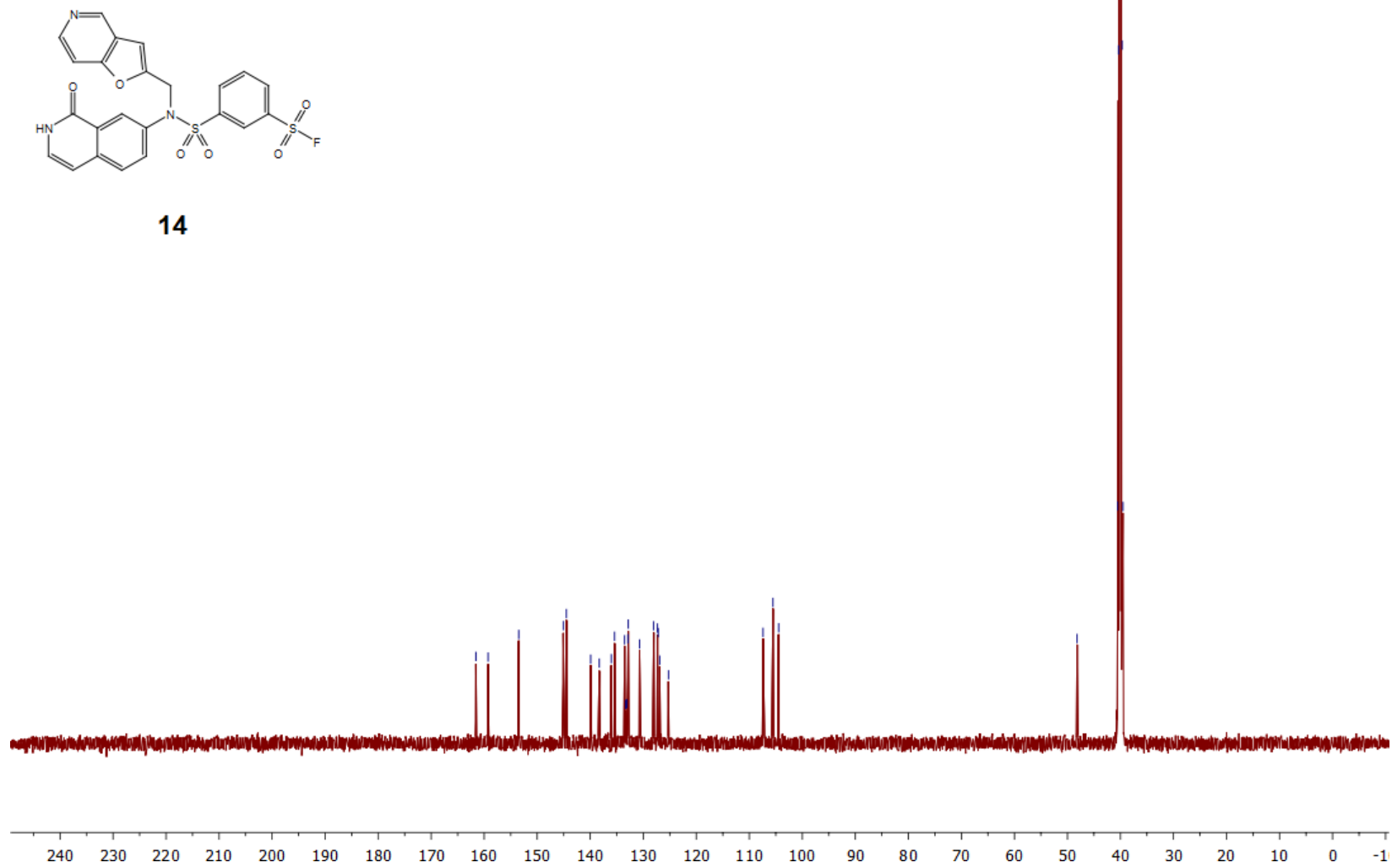

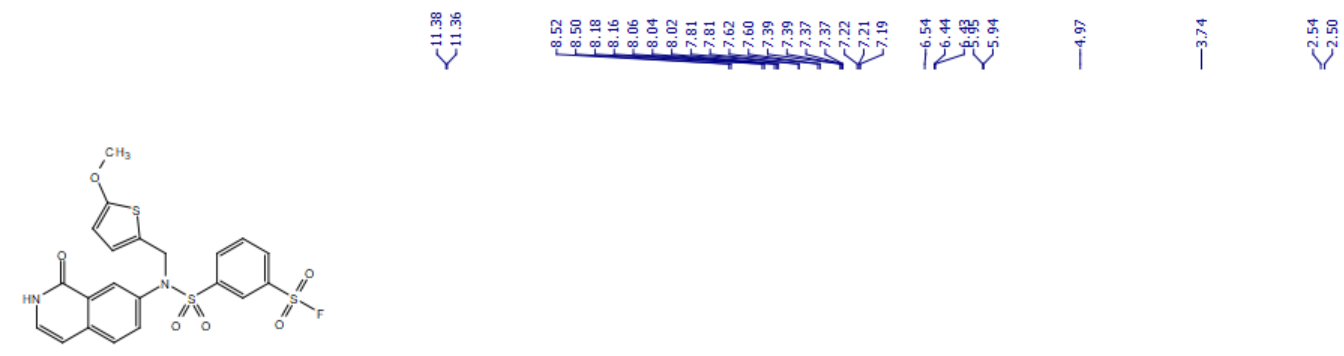

15

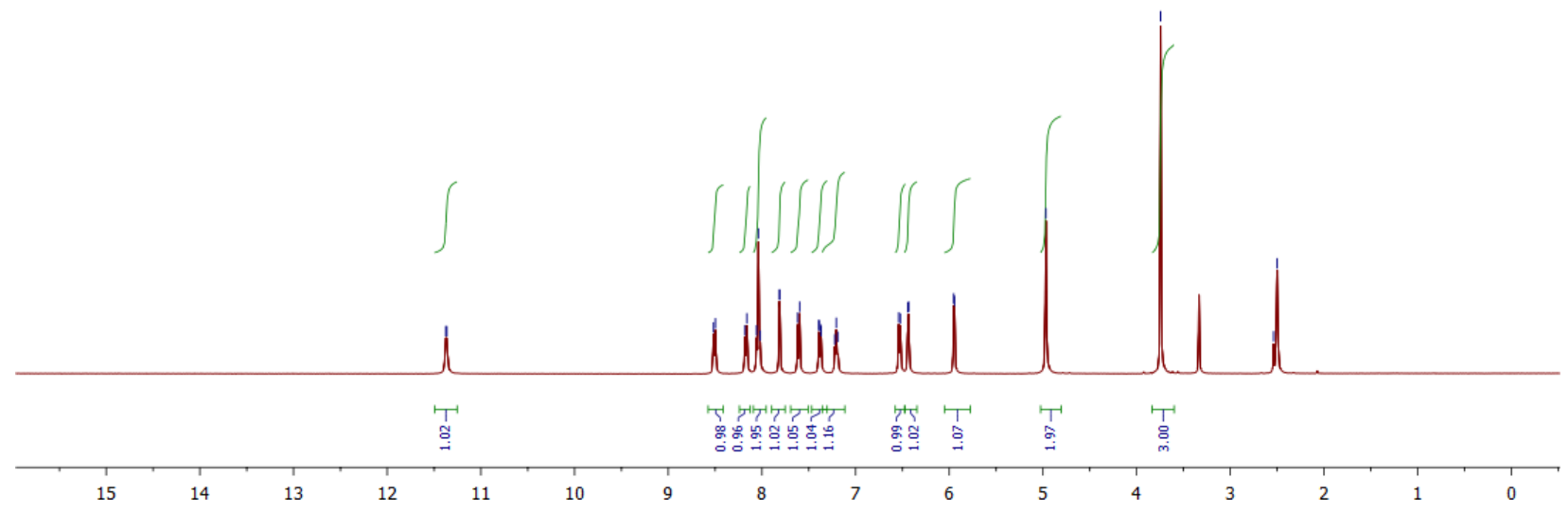



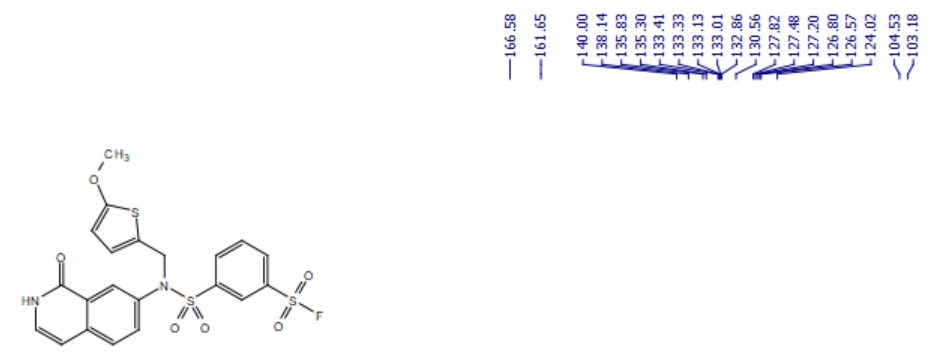

15
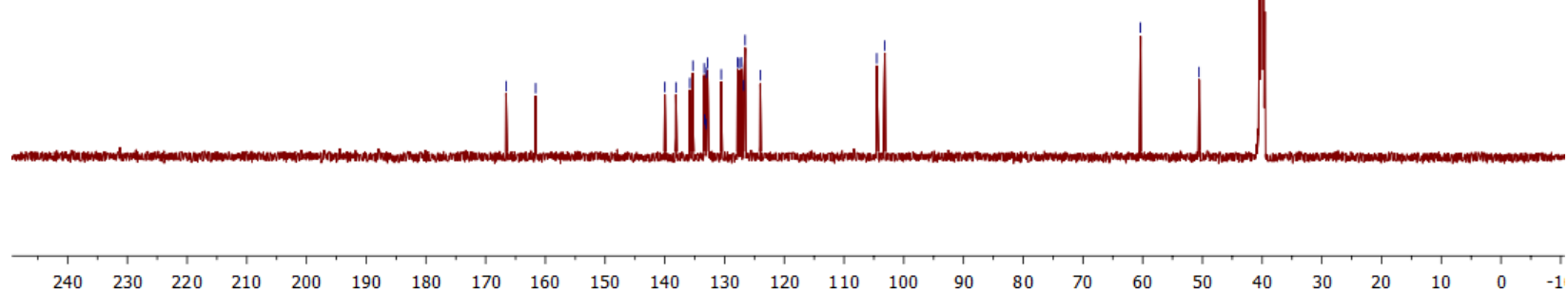